\title{
THE INFLUENCE OF ANTITAKEOVER STATUTES ON INCORPORATION CHOICE: EVIDENCE ON THE "RACE" DEBATE AND ANTITAKEOVER OVERREACHING
}

\section{GUHAN SUBRAMANIAN ${ }^{\dagger}$}

Commentators have long debated whether competition among states for corporate charters represents a race to the top or a race to the bottom. Race-tothe-top advocates recently have gained ground in this debate on the basis of the general corporate migration to Delaware in the 1990s and empirical evidence suggesting that Delaware incorporation increases shareholder wealth. This Article uses second-generation state antitakeover statutes to shed additional light on this debate. I use a new database of reincorporations from the 1990s to show that managers generally migrate to (and fail to migrate away from) typical antitakeover statutes. Given the robust econometric evidence that these statutes increase managerial agency costs and reduce shareholder wealth, my results are generally consistent with the race-to-the-bottom view. However, I also find some evidence that managers migrate away from the more severe antitakeover statutes in Massachusetts, Ohio, and Pennsylvania, through incorporation choice and opt-out from these statutes. This finding introduces the possibility of "overreaching" in the corporate charter marketplace and suggests potential limits on the race to the bottom. The results have implications for recent developments in corporate charter competition in both the United States and the European Union.

INTRODUCTION

I. BACKGROUND ............................................................... 1802

A. Competition in the Corporate Charter Market........................... 1802

B. A Brief Survey of the Debate ............................................... 1804

C. Econometric Evidence ........................................................ 1807

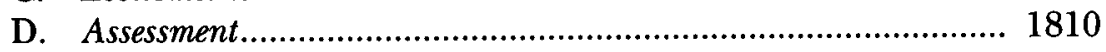

${ }^{\dagger}$ Assistant Professor of Business Administration, Harvard Business School. A.B. Harvard College; J.D. Harvard Law School; M.B.A. Harvard Business School. I thank Constance Bagley, George Baker, Jason Barro, Lucian Bebchuk, Keith Paul Bishop, John Coates, Jill Fisch, Brian Hall, Marcel Kahan, Tom Knox, Mark Roe, Lynn Stout, Leo Strine, and seminar participants at Harvard Business School, Harvard Law School, and the Vanderbilt Conference on Empirical Research in Corporate Law for helpful comments on earlier drafts. I also thank Michelle Kalka for excellent research assistance. The Division of Research at the Harvard Business School provided financial support. 
II. DESCRIPTIVE STATISTICS........................................................... 1813

A. Corporate Charter Stock in 2000 .............................................. 1813

1. Corporate Headquarters vs. State of Incorporation......... 1813

2. Nondefault Incorporation Choices.................................. 1819

B. Corporate Charter Flows in the 1990s...................................... 1820

1. Reincorporations ........................................................ 1820

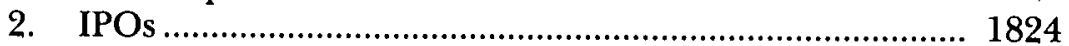

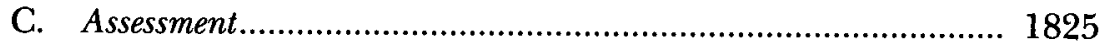

III. A MODEL OF INCORPORATION CHOICE …………................ 1826

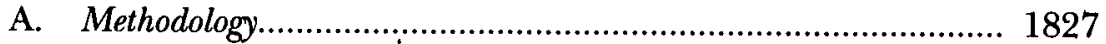

1. The Proliferation of Antitakeover Statutes ....................... 1827

2. The Wealth Effects of Antitakeover Statutes ................... 1829

3. Opt-Out from Antitakeover Statutes ................................ 1831

4. Null Hypothesis................................................................. 1831

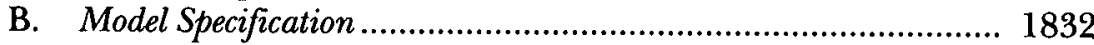

1. Dependent Variable ........................................................... 1834

2. Independent Variables .................................................. 1834

3. Control Variables ............................................................. 1835

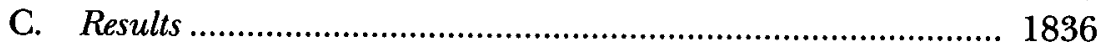

1. Single-Statute Models ..................................................... 1836

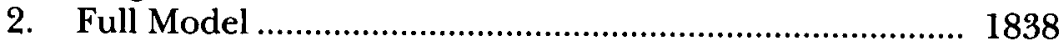

3. Timing Analysis .............................................................. 1844

D. Results from Reincorporating Firms........................................... 1848

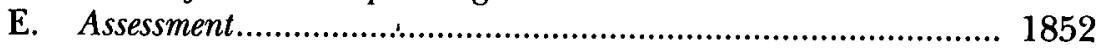

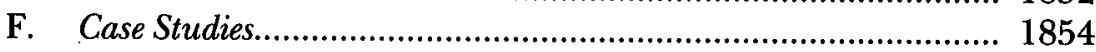

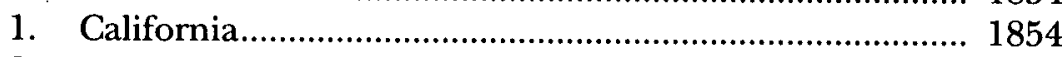

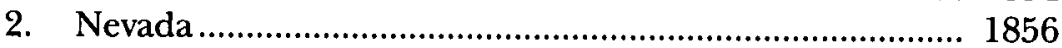

IV. ANTITAKEOVER "OVERREACHING" ....................................... 1857

A. Description of Severe Antitakeover Statutes.................................. 1857

1. Pennsylvania and Ohio .................................................. 1857

2. Massachusetts ................................................................... 1859

B. A Theory of Antitakeover Overreaching....................................... 1860

1. Distributive Element of Severe Antitakeover Statutes ...... 1860

2. Efficiency Element of Severe Antitakeover Statutes......... 1862

3. Assessment...................................................................... 1862

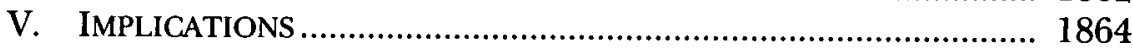

A. The Maryland Unsolicited Takeover Act of 1999 ......................... 1864

B. Takeover Regulation in the United States.................................... 1866

C. Regulatory Competition in the European Union ............................ 1869

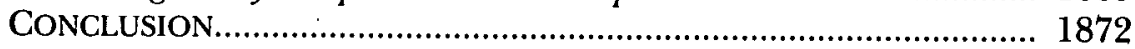

\section{LIST OF FIGURES}

Figure 1: Headquarters State 
Figure 3: State of Incorporation by Headquarters State 1817

Figure 4: Incorporation Choice by Headquarters State 1818

Figure 5: Win/Lose by Headquarters State .....................................1819

Figure 6: Reincorporations by Headquarters State ..........................1823

\section{LIST OF TABLES}

Table 1: 1990s Reincorporations .1821

Table 2: 1990s Reincorporations by Headquarters State .................1824

Table 3: State Antitakeover Statutes ..............................................1828

Table 4: Incorporation Choice-Single-Statute Models...................1837

Table 5: Incorporation Choice-Full Model and Extensions .........1839

Table 6: Incorporation Choice-Timing Analysis .........................1847

Table 7: Reincorporation Choice ....................................................1850

\section{INTRODUCTION}

One of the most important questions in U.S. corporate law is whether competition in the corporate charter market represents a "race to the top" or a "race to the bottom." The answer has implications for whether and to what extent federal legislation should preempt state corporate law. Ralph Winter, ${ }^{1}$ Frank Easterbrook, ${ }^{2}$ Daniel Fischel, ${ }^{3}$ and Roberta Romano ${ }^{4}$ have argued that states compete

1 See Ralph K. Winter, Jr., State Law, Shareholder Protection, and the Theory of the Corporation, 6 J. LEGAL STUD. 251, 251-52 (1977) (concluding that "state corporate legal systems are protective of shareholders and that state regulation is generally preferable to federal").

${ }^{2}$ See Frank H. Easterbrook, Managers' Discretion and Investors' Welfare: Theories and Evidence, 9 DEL. J. CORP. L. 540, 542 (1984) (discussing "some of the ways in which competition ... induces managers to act in the interests of investors, even if each investor is powerless"); Frank H. Easterbrook \& Daniel R. Fischel, Voting in Corporate Law, 26 J.L. \& ECON. 395, 398 (1983) (arguing that "states' legal rules generally provide investors with the sort of voting arrangements they would find desirable if contracts could be arranged and enforced at low cost").

${ }^{3}$ See Daniel R. Fischel, From MITE to CTS: State Anti-Takeover Statutes, the Williams Act, the Commerce Clause, and Insider Trading, 1987 SUP. CT. REV. 47, 84 ("States that enact laws that are harmful to investors will cause entrepreneurs to incorporate elsewhere."); Daniel R. Fischel, The "Race to the Bottom" Revisited: Reflections on Recent Developments in Delaware's Corporation Law, 76 Nw. U. L. REV. 913, 919-20 (1982) (attributing Delaware's preeminence to its success in a "climb to the top" in which shareholders" wealth is maximized, rather than minimized); supra note 2 (citing a work co-authored with Frank Easterbrook).

${ }^{4}$ See Roberta Romano, THE Genius of American Corporate LAW 16 (1993) [hereinafter ROMANO, GENIUS] (stating that "the evidence supports the view that states do compete for the chartering business" and that this "benefits rather than harms shareholders"); Roberta Romano, A Guide to Takeovers: Theory, Evidence, and Regulation, 9 YALE J. ON REG. 119, 119 (1992) (demonstrating that state choices among takeover 
against each other to offer laws that maximize shareholder value, resulting in a race to the top. William Cary, ${ }^{5}$ Lucian Bebchuk, ${ }^{6}$ Alma Cohen, ${ }^{7}$ Allen Ferrell, ${ }^{8}$ and (in the political arena) Ralph Nader ${ }^{9}$ have argued that states cater to managers, whose self-interest often can diverge from the interests of shareholders, resulting in a race to the bottom at least with respect to certain issues.

Commentators on both sides of the debate have noted that their opposing views in fact share fundamental assumptions about the social welfare goal (maximization of shareholder wealth), the states' objective (maximization of incorporation revenue), and managers' decision rule (pursuit of self-interest). ${ }^{10}$ The two views differ only in their assessment of managers' ability to pursue private benefits of control.

statutes can benefit shareholders); Roberta Romano, Competition for Corporate Charters and the Lesson of Takeover Statutes, 61 FORDHAM L. REV. 843, 847 (1993) [hereinafter Romano, Lesson] ("While state competition is an imperfect public policy instrument, on balance it benefits investors."); Roberta Romano, Law as a Product: Some Pieces of the Incorporation Puzzle, 1 J.L. ECON. \& ORG. 225, 272-73 (1985) [hereinafter Romano, Some Pieces] (finding statistical support that reincorporation "is associated, in some situations, with positive abnormal returns for the shareholders").

${ }^{5}$ See William L. Cary, Federalism and Corporate Law: Reflections upon Delaware, 83 YALE L.J. 663, 705 (1974) (describing "this race for the bottom, with Delaware in the lead").

${ }^{6}$ See Lucian Arye Bebchuk, Federalism and the Comporation: The Desirable Limits on State Competition in Corporate Law, 105 HARv. L. REV. 1435, 1440 (1992) (arguing that "state competition produces a race for the top with respect to some corporate issues but a race for the bottom with respect to others"); Lucian Bebchuk, Alma Cohen, \& Allen Ferrell, Does the Evidence Favor State Competition in Corporate Law?, 90 CAL. L. REv. (forthcoming 2002) (manuscript at 2, on file with author) ("[S]tate competition induces states to provide rules that managers, but not necessarily shareholders, favor with respect to corporate law issues that significantly affect managers' private benefits of control ...."); Lucian Arye Bebchuk \& Allen Ferrell, A New Approach to Takeover Law and Regulatory Competition, 87 VA. L. REV. 111, 130 (2001) [hereinafter Bebchuk \& Ferrell, A New Approach] (arguing that "state competition produces a systematic tendency for states to protect incumbent management excessively from takeovers"); Lucian Arye Bebchuk \& Allen Ferrell, Federalism and Corporate Law: The Race to Protect Managers from Takeovers, 99 Colum. L. REV. 1168 (1999) [hereinafter Bebchuk \& Ferrell, Federalism] (using takeover law to demonstrate that state competition suffers from shortcomings that are unlikely to lead to shareholder wealth maximization); Lucian Bebchuk \& Alma Cohen, Firms' Decisions Where to Incorporate 5 (Feb. 2002) (unpublished manuscript, on file with author) ("[T] me more protection from takeovers a state provides, the more successful it is in the market for incorporations.").

${ }^{7}$ Bebchuk, Cohen, \& Ferrell, supra note 6; Bebchuk \& Cohen, supra note 6.

${ }^{8}$ Bebchuk, Cohen, \& Ferrell, supra note 6; Bebchuk \& Ferrell, A New Approach, supra note 6; Bebchuk \& Ferrell, Federalism, supra note 6.

9 See Ralph Nader, Mark Green, \& Joel Seligman, Taming the Giant CORPORATION 60 (1976) ("The entire function of state corporate law has been reduced to reflecting the preferences of the managers of the target corporations.").

${ }^{10}$ Bebchuk, suipra note 6, at 1456; Romano, Some Pieces, supra note 4, at 228. 
Race-to-the-top proponents argue that managers are to a large extent prevented from pursuing their self-interest to the detriment of shareholders by marketplace discipline-notably the capital market, the product market, and the market for corporate control. Race-to-thebottom proponents argue that these forces do not effectively constrain managers.

In the 1970s, the race-to-the-bottom view held sway. In 1976, for example, Richard Jennings stated that the race-to-the-bottom view was "common knowledge," and a year later Winter stated that "[i]t is almost universally the opinion of academic commentators that state corporation codes do not impose sufficiently stringent controls on corporate management and are lax in protecting shareholders." ${ }^{12}$ Yet in the 1980s and 1990s commentators documented the many benefits of Delaware incorporation and argued that the growing tide of reincorporations to Delaware was evidence against a race to the bottom. ${ }^{19}$ This argument gained empirical validation through the recent work of Robert Daines, who provided evidence that Delaware firms have higher Tobin's Qs than non-Delaware firms. ${ }^{14}$ By the mid-to-late 1990s the conventional wisdom among academic commentators had shifted to the race-to-the-top view. In 1995, Michael Klausner stated that "there is broad consensus that state competition to produce corporate law is a race to (or at least toward) the top." In 2000, Jill Fisch reported that " $[\mathrm{m}]$ ost corporate law scholars . . . align themselves with

" Richard W. Jennings, Federalization of Corporate Law: Part Way or All the Way, 31 BUS. LAW. 991 (1976).

${ }_{12}$ Winter, supra note 1, at 251. For example, in June 1976, eighty law professors signed a letter endorsing a role for the national government in corporate law. Letter from David L. Chambers, Professor of Law, The University of Michigan Law School, to United States Senate Committee on Commerce (June 1976), cited in Romano, Lesson, supra note 4, at 847 n.14; see also Mark J. Loewenstein, Delaware as Demon: Twenty-Five Years After Professor Cary's Polemic, 71 U. Colo. L. REv. 497, 499 (2000) ("Professor Cary's [race-to-the-bottom] article received a generally warm reception ....").

${ }_{19}$ See, e.g., Romano, Some Pieces, supra note 4, at 279-81 (discussing characteristics of the corporate charter market that influence the migration of corporations to Delaware); Demetrios G. Kaouris, Note, Is Delaware Still a Haven for Incorporation?, 20 DEL. J. CORP. L. 965, 1011 (1995) (concluding that Delaware retains its advantage over other states because of the "combination of its flexible corporate code, the responsiveness of its legislature, the wealth of legal precedent, its efficient and knowledgeable court system, and its business-like Secretary of State's Office").

${ }^{14}$ See Robert Daines, Does Delaware Law Improve Firm Value?, 62 J. FIN. ECON. 525, 533,555 (finding that Delaware firms were worth $5 \%$ more in 1996, on average, and received more takeover bids than firms incorporated elsewhere).

${ }^{15}$ Michael Klausner, Corporations, Corporate Law, and Networks of Contracts, 81 VA. L. REv. 757, 842 (1995). 
Winter., ${ }^{16}$ This consensus represents a dramatic turn from the "almost universal[]" endorsement of the race-to-the-bottom view two decades earlier. $^{17}$

Along with contemporaneous work by Bebchuk and Cohen, ${ }^{18}$ this Article takes a new approach to assess the nature of competition in the corporate charter marketplace. The starting point for the analysis is the wave of antitakeover statutes that were passed by a majority of states in the late 1980s and early 1990s. Econometric analyses of these statutes consistently find that they reduce shareholder wealth; the most common explanation is the expectation (whether correct or not) ${ }^{19}$ that such statutes reduce the likelihood of a takeover and hence reduce the likelihood of a takeover premium for shareholders. Antitakeover statutes also seem to increase managerial agency costs at an operational level..$^{20}$

These findings from the financial economics literature provide the opportunity for a relatively clean empirical test: do managers migrate to or away from antitakeover statutes? Race-to-the-top theorists predict that managers will migrate away from such statutes. ${ }^{21}$ Race-tothe-bottom theorists predict that managers will migrate to such statutes. $^{22}$ Examining managers' response to antitakeover statutes, then, focuses squarely on the critical question-the question on which the

${ }^{16}$ Jill E. Fisch, The Peculiar Role of the Delaware Courts in the Competition for Corporate Charters, 68 U. CIN. L. REV. 1061, 1065 (2000); see also Roberta Romano, The State Competition Debate in Corporate Law, 8 CARDOZO L. REV. 709, 711 (1987) ("Winter's critique is devastating to Cary's analysis because Cary completely overlooked the interaction of markets on managers' incentives.").

${ }^{17}$ See Ralph K. Winter, Foreword to ROMaNo, GENIUS, supra note 4, at xiii (describing Romano's work as "a major event in an intellectual revolution").

${ }^{18}$ Bebchuk \& Cohen, supra note 6.

${ }^{19}$ See Lucian Arye Bebchuk, John C. Coates IV, \& Guhan Subramanian, The Effect of Takeover Defenses (May 2001) (unpublished manuscript, on file with author) (finding no evidence that state antitakeover statutes deter takeover bids).

${ }^{20}$ See, e.g., MARIANNE BERTRAND \& SEndHIL Mullainathan, Corporate Governance ANd Executive Pay: Evidence from Takeover Legislation 4 (Mass. Inst. Tech., Working Paper, 1999) (finding that executive pay increases in firms newly covered by certain antitakeover statutes); MARIANNE BERTRAND \& SENDHIL MULLAINATHAN, ENJOYNG THE QUIET LIFE? MANAGERIAL BEHAVIOR FOLLOWING ANTITAKeOVER Legislation (Mass. Inst. Tech., Working Paper, 2000) (finding that business combination statutes lead to a decrease in plant-level efficiency); Gerald T. Garvey \& Gordon Hanka, Capital Structure and Comporate Control: The Effect of Antitakeover Statutes on Firm Leverage, 54 J. FiN. 519, 526-27 (1999) (finding that firms in states with antitakeover statutes have lower leverage).

${ }^{21}$ See, e.g., Romano, Lesson, supra note 4, at 859 tbl.1 (finding that the majority of firms opted out of Pennsylvania's 1990 Takeover Statute).

${ }^{22}$ See, e.g., Bebchuk, supra note 6, at 1467-70. 
debate turns-as to whether managers can pursue private benefits of control to the detriment of shareholders.

Using a large sample of U.S. public companies, I find evidence that managers generally migrate to antitakeover statutes. Specifically, I find that managers of public companies are $26 \%$ more likely to remain in their headquarters state (instead of incorporating in Delaware or in a third state) if the headquarters state has a control share acquisition statute, a business combination statute, and a pill validation statute, the three statutes often thought to be the most important among the typical "second generation" state antitakeover statutes. I also find that fair price statutes, which do not seem to reduce shareholder value, also do not seem to influence the incorporation decision. Thus, managers migrate to antitakeover statues that are generally thought to reduce shareholder value, and are not influenced by antitakeover statutes that do not. These results continue to hold when I examine the flow of reincorporations from the 1990s rather than the stock of incorporations in 2000. Viewed as a whole, these results are generally consistent with the race-to-the-bottom view.

However, closer analysis of the most potent antitakeover statutesin Pennsylvania, Massachusetts, and Ohio-suggests limits on this view. I find some evidence that managers migrate away from these statutes, both through their incorporation decisions and through optout. This finding suggests potential limitations on managers' ability to entrench themselves, perhaps due to the emergence of institutional shareholder activism in the 1990s, and suggests that these three states may have "overreached" in the corporate charter marketplace.

In general, these results support the view that the federal government should play a greater role in providing corporate law for U.S. public companies. ${ }^{23}$ They also suggest that recent movements in the European Union toward greater competition for corporate charters among member states may be misguided. Finally, these results have counterintuitive implications for one specific development in the U.S. corporate charter marketplace. Race-to-the-bottom theorists point to Maryland's Unsolicited Takeover Act of 1999—by far the most potent antitakeover statute that has appeared to date-as the latest and most extreme manifestation of their view. Yet the empirical evidence from the experience in Pennsylvania, Ohio, and Massachusetts suggests that

${ }^{23}$ E.g., NADER, GREEN, \& SELIGMAN, supra note 9, at 70-71 (arguing that federal chartering control is necessary to "contain the excessive power and costs of corporate power"); Bebchuk \& Ferrell, A New Approach, supra note 6, at 151-55 (highlighting the reasons why federal intervention is necessary in the area of takeover law). 
Maryland may have overreached.

The remainder of this Article proceeds as follows. Part I provides background information on the corporate charter marketplace and reviews the prior literature. Part II presents basic descriptive statistics. Part III presents the methodology and results from the empirical tests. Part IV examines the experience of Pennsylvania, Ohio, and Massachusetts, three states with potent antitakeover statutes. Part V provides implications of these results for recent developments in the United States and in the European Union.

\section{BACKGROUND}

\section{A. Competition in the Corporate Charter Market}

U.S. corporations are governed by their state of incorporation, regardless of the location of their headquarters or where they conduct their business. Corporations are not constrained by their headquarters, location of manufacturing facilities, place of business, or other operational factors in deciding where to incorporate. ${ }^{24}$ Moreover, reincorporation from one state to another is relatively inexpensive, ${ }^{25}$ and typically qualifies as a tax-free reorganization under $\$ 368(\mathrm{a})$ of the U.S. tax code. ${ }^{26}$ The most important constraint on reincorporations is

${ }^{24}$ Cf. Aspen Technology Inc. Proxy Statement 10 (Dec. 1, 1997) ("The Reincorporation [from Massachusetts to Delaware] will not result in any change in the Company's business, assets or liabilities, will not cause its corporate headquarters to be moved and will not result in any relocation of management or other employees."), available at http://www.sec.gov/Archive/edgar/data/929940/0000950135-97004822.txt.

${ }^{25}$ See Romano, Some Pieces, supra note at 4, at 246 (finding "a typical cost of approximately $\$ 40,000$ " for reincorporation in 1985 , equivalent to approximately $\$ 70,000$ in 2001). Admittedly, this figure captures only the cost of reincorporations that occur, leaving open the possibility that other reincorporations are deterred due to cost. Note, however, that reincorporation costs are one-time costs, while benefits are ongoing. Assuming a $10 \%$ discount rate, for example, a company would only need to find $\$ 7,000$ of ongoing annual benefit (e.g., from higher-quality corporate law) in order to cost-justify the typical reincorporation expense.

${ }^{26}$ If the reincorporation qualifies as a $\$ 368$ reorganization, shareholders do not recognize any gain or loss on their shares and carry over their basis in the old shares to the new shares. I.R.C. $\S \S 354,368$ (a) (1994). Moreover, holders of restricted shares can typically tack the holding period of their shares for purposes of Rule 144, which governs sales of restricted securities. Alan K. Austin \& Gregory M. Priest, Resales of Securities Under Rule 144 and Rule 144A, in SECURITIES FILINGS 1999, at 65, 80 (1999). In contrast, under current law reincorporation in the European Union typically requires a liquidation of the company, Karsten Engsig Sørensen \& Mette Neville, Corporate Migration in the European Union, 6 COLUM. J. EUR. L. 181, 185 (2000), though this rule may be changing, see infra Part V.C (noting two recent developments in this area that may 
procedural rather than economic: because corporations generally reincorporate by merging into a new company that is incorporated in the destination state, and because mergers generally require board authorization and shareholder approval, ${ }^{27}$ managers (and the board) cannot reincorporate on their own, nor can shareholders propose reincorporations on their own.

States compete to have companies incorporated within their boundaries in order to maximize their corporate charter revenues. ${ }^{28}$ New Jersey was the original leader in this market, ${ }^{29}$ but lost its lead to

open the door for U.S.-style charter competition).

${ }^{27}$ See Robert Charles ClaAk, Corporate LAW $\$ 10.2 .4$ (1986) (describing shareholder approval requirements for mergers). Depending on pre-reincorporation state law and the company's pre-reincorporation charter, approval of the merger may require a supermajority vote by shareholders. Compare Data Translation Inc. Proxy Statement (Mar. 8, 1996) (two-thirds approval), available at http://www.sec.gov/edgar/searchedgar/webuser.htm, and Aspen Technology Inc. Proxy Statement 9 (Dec. 1, 1997) (same), available at http://www.sec.gov/edgar/searchedgar/webuser.htm, with Touchstone Software Corp. Proxy Statement (Nov. 12, 1996) (simple majority approval), available at http://www.sec.gov/edgar/searchedgar/webuser.htm, and Worthington Industries Proxy Statement 8 (August 20, 1998) (same), available at http://www.sec.gov/edgar/searchedgar/webuser.htm.

${ }^{28}$ This is a fundamental assumption of both the race-to-the-top and race-to-thebottom views. Nevertheless, some commentators have questioned whether states other than Delaware truly compete in this marketplace. See Ralph K. Winter, The "Race for the Top" Revisited: A Comment on Eisenberg, 89 ColuM. L. REV. 1526, 1529 (1989) (arguing that "the race to the top may be slow because Delaware is the only state devoted exclusively to maximizing franchise taxes"); Marcel Kahan \& Ehud Kamar, The Myth of State Competition in Corporate Law 1 (2002) (unpublished manuscript, on file with author) [hereinafter Kahan \& Kamar, Myth] ("[O]ther than Delaware, no state has made significant and sustained efforts to attract incorporations."). Others have pointed out that Delaware's dominant position makes perfect competition in this marketplace a dubious proposition. See Marcel Kahan \& Ehud Kamar, Price Discrimination in the Market for Comporate Law, 86 CORNELL L. REV. 1205, 1210-14 (2001) [hereinafter Kahan \& Kamar, Price Discrimination] (arguing that the market for incorporations is not perfectly competitive because Delaware has competitive advantages that give it market power); Ehud Kamar, A Regulatory Competition Theory of Indeterminacy in Corporate Law, 98 COLUM. L. REV. 1908, 1911-12 (1998) (describing the corporate law regulation market as "imperfect competition"); Klausner, supra note 15, at $846-47$ (discussing the role of network externalities in preserving Delaware's dominance in the incorporation marketplace). Anecdotal evidence suggests that states attempt to compete in this market, see, e.g., Keith Paul Bishop, The Delaware of the West: Does Nevada Offer Better Treatment for Directors?, INSIGHTS, Mar. 1993, at 20, 20 ("In recent years, . . . Nevada has amended its corporate law in a rather obvious effort to entice management into making Nevada its corporate home."), and this Article provides evidence that competition in the corporate charter market is actually more vibrant than prior commentators have suggested, infra Figures 3 \& 4.

${ }^{29}$ See Joel Seligman, A Brief History of Delaware's General Corporation Law of 1899, 1 DEL. J. CORP. L. 249, 265-68 (1976) (discussing the series of statutes enacted between 
Delaware after making restrictive amendments to its corporate law in 1913. ${ }^{30}$ Delaware quickly gained a dominant share and never looked back: by 1965, 35\% of companies listed on the New York Stock Exchange (NYSE) were Delaware companies; ${ }^{31}$ by 1973 this number had risen to $40 \% ;^{32}$ and by 2000 approximately half of NYSE companies were incorporated in Delaware. ${ }^{33}$ Among firms overall, Delaware in the 1990s had achieved a dominant share of the existing corporate charter market $(50 \%)$, the reincorporation market $(54 \%)$, and the IPO charter market (approximately 60\%). ${ }^{34}$ Delaware's dominance is an important stylized fact in the "race" debate described below.

\section{B. A Brief Survey of the Debate}

The modern "race" debate started with William Cary's now-famous 1974 article in the Yale Law Joumal. ${ }^{35}$ Starting from the premise that Delaware's sole interest was maximizing its incorporation revenues, ${ }^{36}$ Cary highlighted a series of issues on which the Delaware legislature and courts had catered to managers' interests at the expense of

1891 and 1896 that made New Jersey a success in "the charter-mongering business").

Id. at 270-71.

${ }^{31}$ See Cary, supra note 5, at 671 (citing GeORGE C. SEWARD, BaSIC CoRPorate PRACTICE 5 (1966)).

${ }^{32}$ See id. at 671 (citing the New York Stock Exchange Directory dated January 5 , 1973, at pages 701-851).

${ }^{33}$ Delaware Division of Corporations, at http://www.state.de.us/corp/index.htm (last visited Apr. 27, 2002).

34 Infra Part II.B.2.

${ }^{35}$ Cary, supra note 5.

${ }^{36}$ See id. at 668, 684 ("Stimulating incorporation in Delaware has some of the flavor of a community chest drive. . . Perhaps there is no public policy left in Delaware corporate law except the objective of raising revenue."). Delaware's actions were "understandabl[e]" because of the state's heavy dependence on corporate charter revenues. Id. at 668 . At the time of Cary's writing, Delaware's incorporation revenues represented nearly $23 \%$ of the total tax collections for the state. See Cary, supra note 5, at 669 (reporting $\$ 52$ million in corporate franchise taxes in 1971 , out of a total of $\$ 222$ million in state tax collections for Delaware). However, 1971 appears to have been the high point of Delaware's dependency on franchise revenues. Romano calculates that the ratio dropped to $19 \%$ in 1972 , and averaged approximately $16 \%$ over the period 1960-1990. ROMANO, GENIUS, supra note 4, at 7-8. More recently, Kahan and Kamar report $\$ 424.4$ million of corporate charter revenues for Delaware in 1999, representing $19 \%$ of Delaware's total tax base. Kahan \& Kamar, Price Discrimination, supra note 28, at 1251 tbl.3. Including related fees, the corporate charter industry may contribute as much as one-quarter of Delaware's total budget. See Albert B. Crenshaw, Delaware Inc., WASH. POST, May 7, 2000, at $\mathrm{H} 1$ (calculating nearly $\$ 475$ million in incorporation fees plus "other spending from the lawyers and experts needed when companies register, litigate, merge, and, sometimes, fail"). 
shareholders. ${ }^{37}$ Cary then argued that other states would be forced to compete with Delaware in a "race for the bottom." ${ }^{\text {,88 }}$ States would develop competing corporate codes that favored managers' interests, but that did not maximize value for shareholders. ${ }^{39}$ The solution, Cary believed, was federalization of substantial portions of corporate law rather than leaving it to the states. ${ }^{40}$

In an equally influential article published three years later, Ralph Winter responded to Cary's assessment with the argument that capital markets, product markets, and the market for corporate control would provide an effective check against a race to the bottom. ${ }^{41}$ If Delaware companies allowed managers to exploit shareholders systematically while other states did not, shareholders in Delaware companies would earn lower returns than shareholders in companies chartered in other states. ${ }^{42}$ Investors would pay less for the stock of Delaware companies. Delaware companies would face a higher cost of capital, which would make it difficult for them to compete in product markets. Eventually, Delaware companies would be taken over by acquirers who would increase shareholder value simply by reincorporating to another state. To avoid this sequence of events, Delaware (and other states) would compete against each other in a "race for the top" to develop rules that maximized shareholder value. ${ }^{49}$

In response to Winter and others, Bebchuk argued that state competition is unlikely to work well with respect to issues that are "significantly redistributive" and that "directly implicate the strength of market discipline" (notably antitakeover statutes). ${ }^{44}$ Bebchuk and Ferrell advocate "choice-enhancing federal intervention" as a response to this perceived structural flaw in the corporate charter marketplace. $^{45}$

At the other end of the policy spectrum from Bebchuk, Romano

${ }^{37}$ See Cary, supra note 5, at 672-84 (citing issues such as duty of care, proxy contests, takeovers, and fairness between parent and subsidiary).

${ }^{38} I d$. at 705 .

${ }^{39}$ Id. at 665-66.

Id. at $700-03$.

${ }^{41}$ Winter, supra note 1 , at 256.

42 Id. at 257.

4s Id.

44 Bebchuk, supra note 6, at 1461-70; see also Loewenstein, supra note 12, at 530 (arguing that the disciplining effect of the market for corporate control "assumes an active, unencumbered market for takeovers, an assumption that is simply counterfactual").

Bebchuk \& Ferrell, A New Approach, supra note 6, at 149-56. 
points to Delaware's relatively moderate takeover statute as evidence that the general migration to Delaware is not a race to the bottom. ${ }^{46}$ Moreover, she reports that a large fraction of Pennsylvania firms opted out of the Pennsylvania antitakeover statute after it was passed in 1991: out of 308 firms incorporated in Pennsylvania in that year, $17 \%$ opted out completely, another $25 \%$ opted out of certain provisions, and only $23 \%$ did not opt out at all (another $35 \%$ were unidentified)..$^{47}$ Romano concludes from this analysis that "Pennsylvania's disgorgement statute provides a good example of the beneficent effect of state competition. ... The large-scale withdrawal by Pennsylvania firms from inclusion under a value-decreasing statute is powerful support for the acuity of Winter's insight in his critique of Cary."

Other views have been put forward as well. Bernard Black argues that corporate law generally does not matter and that choice of domicile is therefore unimportant. ${ }^{49}$ As a partial response, the evidence presented in this Article suggests that managers at least act as if state antitakeover statutes matter. ${ }^{50}$ Macey and Miller, ${ }^{51}$ Carney, ${ }^{52}$ and Bratton and McCahery ${ }^{53}$ use variations of an "interest group" lens to high-

${ }^{46}$ Romano, Lesson, supra note 4 , at 855-56.

${ }^{47}$ Id. at 859 tbl.1.

48 Id. at 858-59. Such is the strength (and consistency) of Romano's belief in the benefits of state competition that in subsequent work she advocates delegating many aspects of federal securities law back to the states. See Roberta Romano, Empowering Investors: A Market Approach to Securities Regulation, 107 YALE L.J. 2359, 2361 (1998) ("This Article contends that the current legislative approach to securities regulation is mistaken .... [This Article] advocates instead a market-oriented approach of competitive federalism that would expand, not reduce, the role of the states in securities regulation.").

${ }^{49}$ See Bernard S. Black, Is Corporate Law Trivial?: A Political and Economic Analysis, 84 Nw. U. L. REV. 542, 593 (1990) (expounding his "triviality hypothesis that, with limited exceptions for changes in law and the benefits and costs of paternalism, state corporate law is trivial").

${ }^{50}$ Infra Parts III-IV; see also John C. Coates, IV \& Guhan Subramanian, A Buy-Side Model of MEंA Lockups: Theory and Evidence, 53 STAN. L. REV. 307, 319-37 (2000) (presenting large-sample evidence that important Delaware decisions on M\&A lockups influence practitioners in their choice of deal protection device).

${ }^{51}$ See Jonathan R. Macey \& Geoffrey P. Miller, Toward an Interest-Group Theory of Delaware Corporate Law, 65 TEX. L. REV. 469 (1987) (arguing that states exploit the corporate agency relationship by offering less efficient rules that are nevertheless attractive to management).

${ }^{52}$ See William J. Carney, The Production of Corporate Law, 71 S. CAL. L. REV. 715, 716 (1998) (using an "interest group theory to explain why states may attempt to compete with Delaware," and exploring the two interest groups of "local corporate lawyers and managers of firms incorporated within a state" that benefit from modern corporate laws).

\footnotetext{
${ }^{59}$ See William W. Bratton \& Joseph A. McCahery, Regulatory Competition, Regulatory
} 
light the importance of various constituencies (management, courts, lawyers, etc.) in preserving Delaware's dominance. In doing so these studies generally reach a middle-ground view on the race debate. ${ }^{54}$

\section{Econometric Evidence}

Though event studies offer relatively consistent results on the race debate, these studies suffer from methodological flaws that make their results difficult to interpret. Among seven event studies of reincorporations, five find positive abnormal returns, ${ }^{55}$ and two more find mixed results. $^{56}$

The event study methodology is problematic in the particular context of reincorporations because companies often announce changes in strategy, or additional takeover defense mechanisms, or both, in conjunction with the reincorporation decision. As just one example, Foothill Independent Bancorp's reincorporation from California to Delaware in March 2000 was accompanied by the elimination of cu-

Capture, and Corporate Self-Regulation, 73 N.C. L. REV. 1861 (1995) (describing charter competition as an example of regulatory capture by corporate management).

${ }^{54}$ See id. at 1948 ("State law remains the best vehicle for realizing those possibilities [for productive firm contracting], but a demand-side barrier prevents state law experimentation."); Carney, supra note 52, at 720, 722 ("Two interest groups have dominated the development of American corporate law-corporate lawyers and corporate managers. . . . This does not mean, however, that corporate law changes necessarily operate to the disadvantage of shareholders.").

${ }^{55}$ See Michael Bradley \& Cindy A. Schipani, The Relevance of the Duty of Care Standard in Corporate Governance, 75 IowA L. REv. 1, 67 (1989) (finding a 6.2\% cumulative abnormal return in the window of thirty to ten days before shareholders received proxy materials describing the reincorporation); Peter Dodd \& Richard Leftwich, The Market for Corporate Charters: “Unhealthy Competition" Versus Federal Regulation, 53 J. Bus. 259, 27475 (1980) (finding positive abnormal returns in the twenty-four-month period before the reincorporation); Allen Hyman, The Delaware Controversy-The Legal Debate, 4 DEL. J. CORP. L. 368, 385-87, 396 tbl.1, 397 tbl.2 (1979) (finding positive abnormal returns in the days and weeks surrounding the announcement of reincorporation to Delaware); Jeffry Netter \& Annette Poulsen, State Corporation Laws and Shareholders: The Recent Experience, 18 FIN. MGMT. 29, 36 (1989) ("The cumulative abnormal returns for the Delaware firms are positive...."); Romano, Some Pieces, supra note 4, at 271-72 (finding significant positive abnormal returns in a ten-day window around the reincorporation for a portfolio of all reincorporating firms, and even more so for firms reincorporating for acquisition purposes).

${ }_{56}$ See Randall A. Heron \& Wilbur G. Lewellen, An Empirical Analysis of the Reincorporation Decision, 33 J. Fin. \& QUANTITATIVE ANAlysis 549 (1998) (finding positive abnormal returns for reincorporations that establish limits on director liability and negative abnormal returns for reincorporations that erect takeover defenses); Pamela $\mathbf{P}$. Peterson, Reincorporation: Motives and Shareholder Wealth, 23 FIN. REV. 151, 159-60 (1988) (finding positive abnormal returns unless the reincorporation increases takeover defenses). 
mulative voting, a doubling of the number of authorized shares of common stock, the creation of a new class of blank-check preferred stock, and the installation of a staggered board of directors. ${ }^{57}$ It would be difficult if not impossible to isolate the market response to reincorporation when these other changes are being made simultaneously. Bebchuk argues that managers may have incentives to time their reincorporation decision with the release of other positive news in order to mask the negative impact of the reincorporation. ${ }^{58}$ More generally, most commentators acknowledge that reincorporating companies are not a random draw of all companies, and that reincorporation may be endogenous to firm performance. ${ }^{59}$ Thus, event studies of reincorporations do not provide a clean test, and studies finding positive abnormal returns may be picking up other effects.

In the most recent econometric contribution to this debate, Robert Daines takes a different approach. Daines uses Tobin's $Q$ as an estimate of firm value and finds that Delaware firms are worth significantly more than firms incorporated elsewhere. ${ }^{60}$ Daines further finds that Delaware firms are more likely to attract takeover bids than companies in other states. ${ }^{61}$ In view of the well-accepted finding that takeovers increase returns for target shareholders, he argues that the increased likelihood of takeover in Delaware is at least partially responsible for the higher $Q$-ratios that he finds. ${ }^{62}$ Daines concludes from this evidence that Delaware is "not lead[ing] in a national 'race to the bottom." ${ }^{63}$

Bebchuk and Ferrell respond to Daines with the observation that firm quality may be endogenous to the incorporation decision. ${ }^{64}$ They hypothesize that Daines may be capturing a selection effect having little to do with the quality of Delaware law, though they present no evidence in support of this view and acknowledge that Daines has made

${ }^{57}$ Brenda L. Moore, Foothill Independent Bancorp Seeks to Ward Off Any Future Takeover, WALL. ST. J. (California ed.), Mar. 15, 2000, at C2.

${ }^{58}$ Bebchuk, supra note 6 , at 1449 \& n.60.

59 See, e.g., Daines, supra note 14, at 527 ("Because reincorporations are not a random sample of firms, event studies of reincorporating firms do not tell us about the effect of Delaware law on the vast majority of firms that never reincorporate after going public.").

${ }^{60}$ Id.

${ }^{61} I d$.

${ }^{62} I d$. at 528 .

${ }^{63} I d$.

${ }^{64}$ Bebchuk \& Ferrell, A New Approach, supra note 6, at 137-38. 
"considerable effort" to control for this possibility. ${ }^{65}$ Bar-Gill, Barzuza, and Bebchuk provide a theoretical response to Daines. ${ }^{66}$ They construct a model showing, first, that Delaware companies will reap benefits from Delaware's legal infrastructure and from network externalities, and second, that Delaware has incentives to charge below the full benefit that these firms reap in order to discourage other states from challenging its dominance. ${ }^{67}$ This underpricing of Delaware corporate law could fully explain the higher Tobin's Qs that Daines reports.

In current work; I find that Delaware firms had consistently higher Tobin's $Q$ in the early 1990s, confirming Daines's result for this period, but the magnitude of this effect diminishes over time and seems to disappear entirely by the mid-to-late $1990 \mathrm{~s}^{68}$ This finding is not inconsistent with Daines's itself, which ends its sample in 1996 and finds that results for the last two years (1995 and 1996) are not statistically significant at $95 \%$ confidence. $^{69}$ Nevertheless, commentators have assumed its robustness-one prominent Wall Street Journal reporter, for example, reports that in 1996 "companies incorporated in Delaware were worth $5 \%$ more than companies incorporated elsewhere," but fails to note that the coefficient used to make this estimation is only significant at $90 \%$ confidence. $^{70}$ Still, the argument presented in this Article does not depend on challenging the Daines result. The theoretical response to Daines offered by Bar-Gill, Barzuza, and Bebchuk is

${ }^{65}$ Id.

66 See Oren Bar-Gill, Michal Barzuza, \& Lucian A. Bebchuk, The Market for Corporate Law (July 2001) (unpublished manuscript, on file with author).

${ }^{67} I d$. at 26 . The model provides a formalization of certain features of corporate charter competition noted in a qualitative way by Klausner. See Klausner, supra note 15 , at 77489 (describing these features in the context of network externalities).

${ }^{68}$ See Guhan Subramanian, The Disappearing Delaware Effect (June 2002) (unpublished manuscript, on file with author).

${ }^{69}$ Daines, supra note 14, at 535 tbl.3; see also PAUl A. GoMPERS, JOY L. ISHII, \& ANDREW METRICK, CORPORATE GOVERNANCE AND EQUITY PRICES 28 tbl.10 (Nat'l Bureau of Econ. Research, Working Paper No. 8449, 2001) (finding a negative correlation between Tobin's $Q$ and Delaware incorporation, after controlling for their "governance index," but acknowledging that the difference from Daines's result "may be due to differences in the samples, time periods, or control variables").

${ }^{70}$ Steven Lipin, Deals $\mathcal{E}$ Deal Makers: Firms Incorporated in Delaware Are Valued More by Investors, WALL ST. J., Feb. 28, 2000, at C21; see also Bebchuk \& Ferrell, A New Approach, supra note 6 at 137-38 (pointing out theoretical objections to Daines's finding and offering alternative explanations, but not questioning the basic econometric result); Martin Lipton \& Paul K. Rowe, Pills, Polls and Professors: A Reply to Professor Gilson 26 (NYU Ctr. for Law \& Bus., Working Paper No. CLB-01-006, 2001) (using Daines's result to respond to Gilson's critique of Delaware law), available at http://papers.ssrn.com/sol3/papers.cfm?abstract_id=268520; Bebchuk, Cohen, \& Ferrell, supra note 6 (manuscript at 8-13) (same). 
sufficient to reconcile the findings reported here with Daines. ${ }^{71}$

\section{Assessment}

While commentators continue to disagree about the nature of competition in the corporate charter marketplace, both sides agreeand agree that they agree-on three important assumptions that frame this debate. ${ }^{72}$ First, both sides assume that states seek to maximize the number of companies incorporated within their boundaries. ${ }^{73}$ Second, both sides agree that the objective is shareholder wealth maximization. ${ }^{74}$ Third, both sides agree that managers will pursue their own self-interest. ${ }^{75}$ The crux of the debate, then, is the degree of alignment between managers' self-interest and shareholders' interests.

Race-to-the-top advocates point to the general migration of companies to Delaware over the past twenty years as evidence in support of their view. Delaware's comprehensive case law, its specialized Court of Chancery, its experienced and respected corporate law judges, and its responsiveness to corporate law innovations in other states all provide benefits to corporations. Managers are driven to Delaware in order to reap these benefits and to increase shareholder value. ${ }^{76}$ Romano of-

${ }^{71}$ Bar-Gill, Barzuza, \& Bebchuk, supra note 66; see also infra note 92 (identifying a potential "mix effect" explanation for Daines's result).

${ }_{72}^{72}$ E.g., Bebchuk, supra note 6, at 1451; Romano, Some Pieces, supra note 4, at 228.

${ }^{73}$ See Romano, Some Pieces, supra note 4, at 228 ("[T] he objective of states is revenue maximization, which is thought to depend directly upon the volume of domestic incorporations."); see also Bebchuk, supra note 6, at 1451-55 (pointing out objections to this assumption but concluding that "for the purpose of analyzing the effects of state competition, the appropriate assumption remains that state law is shaped by states' desire to attract incorporations").

${ }^{74}$ See, e.g., Winter, supra note 1, at 256 ("States seeking corporate charters will thus try to provide legal systems which optimize the shareholder-corporation relationship.").

${ }_{75}$ E.g., Cary, supra note 5, at 699; Winter, supra note 1, at 257.

${ }^{76}$ ROMANO, GENIUS, supra note 4, at 9; see also Fisch, supra note 16, at 1064 (attributing Delaware's success in the corporate charter market to "the unique lawmaking function of the Delaware courts"); Kahan \& Kamar, Price Discrimination, supra note 28, at 1212-14 (discussing the sources of Delaware's market power); Kaouris, supra note 13, at 1004 (explaining Delaware's preeminence by noting that it "has a responsive legislature, a flexible statute, specialized courts, a wealth of precedents, an efficient Secretary of State's Office, and efficient corporation service companies"); Touchstone Software Corp. Proxy Statement, supra note 27 (identifying "well established principles of corporate governance," "prominence, predictability, and flexibility of Delaware law," and "increased ability to attract and retain qualified directors" as the board's principal reasons for recommending reincorporation from California to Delaware). 
fers one particular version of this theory, arguing that because Delaware depends so heavily on corporate charter revenues, Delaware can effectively pre-commit to rapid adoption of corporate law innovations from other states. ${ }^{77}$

Race-to-the-bottom advocates, in turn, point to the proliferation of second-generation antitakeover statutes among the states in the late 1980 s and early 1990 s as evidence in support of their view. Such is the strength of the econometric evidence that virtually all commentators agree that these antitakeover statutes reduce shareholder value. ${ }^{78}$ The mere existence of these statutes raises problems for the race-to-the-top view, because, in theory, states should compete with each other to remove such statutes, not to put them in place. ${ }^{79}$ Winter's original explanation on jurisdictional grounds ${ }^{80}$ is no longer valid after the Supreme Court's 1982 decision in Edgar $v$. MITE Corp. ${ }^{81}$ Easterbrook

${ }^{77}$ See Romano, Some Pieces, supra note 4, at 240-41 ("The dependence on franchise tax revenues is forward-looking, warranting that Delaware will continue to respond to corporate needs ....").

78 See, e.g., Bratton \& McCahery, supra note 53, at 1881 n.65 ("A large body of empirical work confirms that the antitakeover statutes had a harmful effect on shareholder value."); Fisch, supra note 16, at 1062 ("[S] tudies indicate that state antitakeover statutes reduce shareholder value."); Romano, Lesson, supra note 4, at 856 ("Empirical research on the wealth effects of takeover laws, is ... most consistent with Cary's view of the harmful effect of state competition."); see also Amanda Acquisition Corp. v. Universal Foods Corp., 877 F.2d 496, 500 (7th Cir. 1989) (Easterbrook, J.) ("If our views of the wisdom of state law mattered, Wisconsin's takeover statute would not survive. ... [W] believe that antitakeover legislation injures shareholders." (footnote omitted)).

${ }^{79}$ See Bebchuk, supra note 6, at 1446 ("[T] he adoption of antitakeover measures by many states presents a puzzle for race for the top adherents, who generally believe that impediments to takeovers are inefficient."); Romano, Lesson, supra note 4, at 846 ("The persistent and rapid proliferation of takeover statutes across the states thereafter presented an apparently thorny question for advocates of federalism.").

${ }^{80}$ See Winter, supra note 1, at 288 ("Because [antitakeover statutes] have an extraterritorial effect, e.g., they apply even when all shareholders reside elsewhere or are scattered among the states, the competition for charters is not the significant factor in the state legislative judgment.").

81457 U.S. 624 (1982). Five years after Winter's remarks, in MITE, the Supreme Court struck down Illinois' first-generation takeover law (which prohibited acquisitions of any firm with substantial assets in Illinois unless an Illinois public official approved) on the grounds that it unduly burdened interstate commerce. MITE, 457 U.S. at 64346; see also Bebchuk, supra note 6, at 1469 n.116 ("The development of state antitakeover laws since the publication of Winter's article therefore undercuts his attempt to square the prevalence of state antitakeover laws with the race for the top logic." (citation omitted)). Mark Roe argues that Winter did not intend for his race-to-the-top theory to apply to state antitakeover statutes, even before MITE. See Mark J. Roe, Takeover Politics, in THE DEAL DECADE: WHAT TAKEOVERS AND LEVERAGED BUYOUTS MEAN FOR CORPORATE GOVERNANCE 321, 348 (Margaret M. Blair ed., 1993) ("Winter did not 
acknowledges that the evidence is inconsistent with his argument, but nevertheless predicts that the race-to-the-top view will hold in the long run, even if "the long run takes time to arrive." diction is untestable. ${ }^{83}$ We know that in our fifteen years of experience with second-generation antitakeover statutes, not a single state has ratcheted down its antitakeover protections. ${ }^{84}$

The primary reason that neither side has been able to deliver a "knock-out blow" in the race debate is that empirical studies have failed to focus on the critical question, in fact the only question that divides race-to-the-bottom and race-to-the-top proponents: Are managers able to pursue private benefits of control to the detriment of shareholders, or do market forces align managers' interests with shareholders' interests? Prior empirical studies have focused either on the actions of states ${ }^{85}$ or the reaction of equity markets, ${ }^{86}$ which are responses to (and indirect effects of) the actions of managers in the model that both sides have adopted. In Part III, I attempt to answer the critical question more squarely by constructing an empirical test

argue that law would always appear to favor shareholders. . . . Nor did he argue that analyses of state competition applied to antitakeover law."). The argument presented here does not depend on characterizing the proliferation of antitakeover statutes as a race to the bottom. Instead, it takes the proliferation of the antitakeover statutes as exogenous and examines companies' responses to them.

A2 Amanda Acquisition, 877 F.2d at 507; see also Bebchuk \& Ferrell, A New Approach, supra note 6, at 131-32 (stating that race-to-the-top proponents reconcile their beliefs with the emergence of antitakeover statutes "by characterizing state takeover law as a fluke, an aberration, an imperfection in the competitive process").

${ }^{8 s}$ The argument also evokes Keynes's famous rejoinder. See JOHN MAYNARD KEYNES, A TRACT ON MONETARY REFORM 80 (1924) ("But this long run is a misleading guide to current affairs. In the long run we are all dead. Economists set themselves too easy, too useless a task if in tempestuous seasons they can only tell us that when the storm is long past the ocean is flat again.").

${ }^{84}$ The closest example to a ratcheting down occurred in Minnesota, which adopted a fair price statute in 1987 and repealed it in February 1988, only to enact it again (with very similar terms) in August 1991. MINN. STAT. ANN. $\$ 302 A .675$ (West Supp. 2002 \& Historical \& Statutory Notes).

${ }^{85}$ See, e.g., Loewenstein, supra note 12, at 501 ("The twenty-five years that have passed since the appearance of Cary's article have not borne out his dire predictions of the progress of Delaware law. That law has not moved inexorably in favor of managers, and to the detriment of the interests of shareholders.").

${ }_{86}$ See e.g., Daines, supra note 14 , at 529 (testing whether firm value is affected by investors paying more or less for assets governed by Delaware law); Dodd \& Leftwich, supra note 55, at 261 ("The ... premise is that investors weigh the costs and benefits of alternative state corporation codes when they consider investments in securities of firms incorporated in particular states."). To be fair, Daines does not claim to be offering direct evidence on the race debate, though he does conclude that "Delaware does not lead in a national 'race to the bottom' in the production of corporate law." Id. at 528 (footnote omitted). 
that focuses on the actions of managers. Before doing so, Part II presents basic statistics on the 1990s corporate charter marketplace.

\section{DesCRIPTIVE Statistics}

Basic statistics on the 1990s market for corporate charters are surprisingly lacking. This Part attempts to fill this gap. ${ }^{87}$ The sample includes all exchange-traded companies in Compustat's database of industrial firms that have both headquarters and incorporation data and positive sales for 2000 . It excludes all foreign companies that are in this database, including those with issued and outstanding American Depository Receipts (ADRs).

\section{A. Corporate Charter Stock in $2000^{88}$}

\section{Corporate Headquarters vs. State of Incorporation}

As a starting point, Figure 1 shows the breakdown of corporate headquarters, defined by Compustat as the company's "primary location," in 2000. It shows that corporate headquarters are spread relatively evenly across the United States, with companies roughly proportional to population. California, New York, and Texas are home to the most companies; collectively they represent a $35 \%$ share by number and a $37 \%$ share by sales. Eight states are home to another onethird of companies, and thirty-nine states, each with no more than a $2 \%$ share, are home to the final one-third of companies.

Figure 2 shows that the breakdown by state of incorporation is considerably more concentrated. It quantifies the well-known fact that Delaware holds a dominant share in the market for corporate charters $-50 \%$ by number of companies, ${ }^{89}$ and $59 \%$ by sales in 2000 . The Herfindahl-Hirschman Index (HHI), a test of market concentration used frequently in the antitrust arena to evaluate horizontal mergers, is 2,662 for the corporate charter industry in 2000-well above the 1800 threshold in the DOJ/FTC Horizontal Merger Guidelines

\footnotetext{
${ }^{87}$ Contemporaneous work by Lucian Bebchuk and Alma Cohen also addresses this deficiency with respect to the corporate charter stock in 1999. Bebchuk \& Cohen, supra note 6.

${ }^{88}$ These analyses were prompted by earlier joint work with John Coates, documenting a California headquarters effect, see infra note 92 (discussing a potential "mix effect" explanation for Daines's Delaware result), as well as invaluable conversations with Lucian Bebchuk.

${ }^{89}$ See also Bebchuk \& Cohen, supra note 6, at A-2 tbl.2 (finding a 51\% market share for Delaware in 1999).
} 


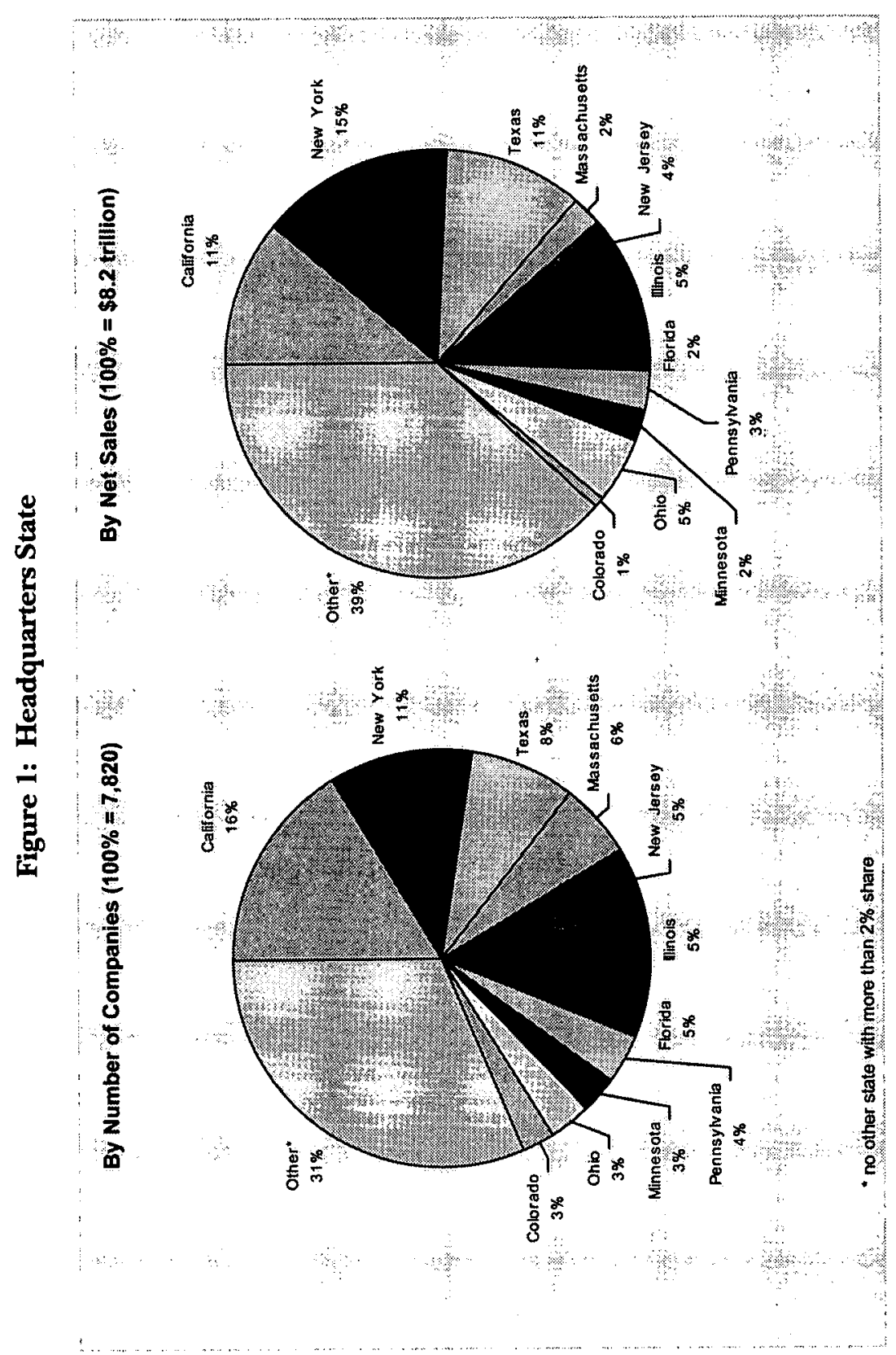


2002] ANTITAKEOVER STATUTES AND INCORPORATION CHOICE 1815

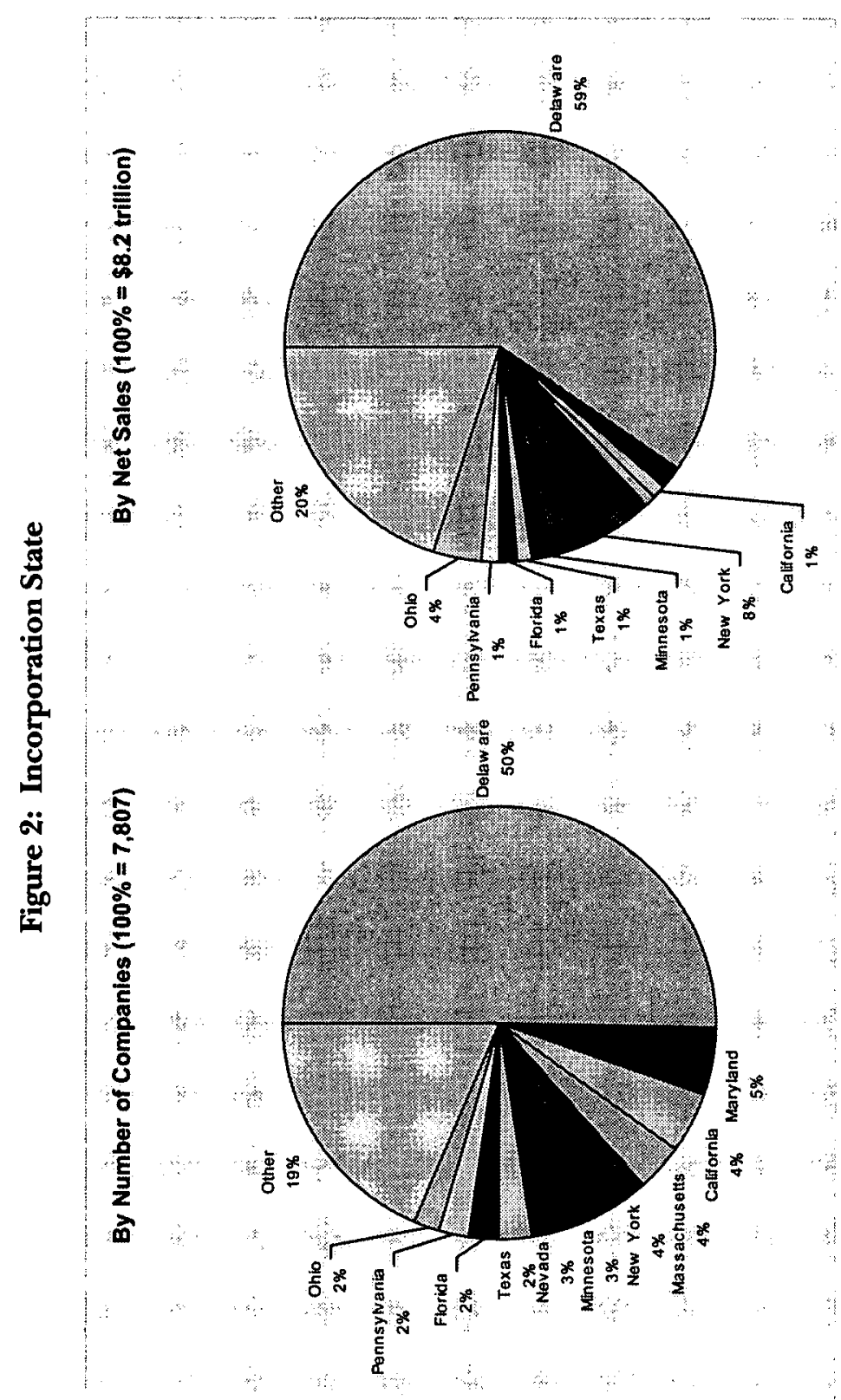


for characterization as a "highly concentrated" industry. ${ }^{90}$ In Part II.B, I explore further to show that Delaware began from a position of considerable strength in the late 1980s and then continued to grow its share through reincorporations and IPO companies in the 1990s, though there are some signs that Delaware's share reached a plateau by the end of the decade.

Figure 2 shows that Maryland holds the second largest share among U.S. public companies in 2000, though almost all of this share is attributable to real estate investment trusts (REITs). ${ }^{91}$ California holds the next-largest share of the corporate charter market, at $4 \%$, though this is substantially less than its $16 \%$ share of corporate headquarters. $^{92}$ I return to this fact in a more rigorous way in the large sample analysis that I present in Part III.

Figure 3 focuses on out-of-state incorporations to states other than Delaware. The left bar chart shows that $15 \%$ of companies are incorporated neither in their home state nor in Delaware. ${ }^{93}$ This statistic is somewhat at odds with the conventional view in prior scholarship that managers consider the charter decision to be between their headquarters state and Delaware. ${ }^{94}$ In fact, some states have made successful inroads against Delaware. The right pie chart shows that three statesMaryland, Nevada, and Massachusetts-control more than half of the

90 DeP'T OF Justice \& Fed. TRAdE COMM'N, Horizontal Merger Guidelines (1992 \& 1997), reprinted in PHILLIP AREEDA \& LOUIS KAPLOW, ANTITRUST ANALYSIS 855 (5th ed. 1997). This finding is consistent with Bebchuk and Cohen's analysis. See Bebchuk \& Cohen, supra note 6, at 31-32 (calculating an $\mathrm{HHI}$ of 2,747 for the corporate charter market overall and a 3,552 HHI among Fortune 500 companies).

${ }^{91}$ Maryland has $56 \%$ share among REITs (103 out of 184 REITs in the data set). When REITs and other financial companies are excluded, Maryland's share drops to $0.7 \%$ of the corporate charter market. I exclude REITs and other financial companies from the regression data set used in Part III. Infra text accompanying note 139.

${ }^{92}$ This finding highlights a potential "mix effect" explanation for Daines's Delaware result. In fact, California represents $22 \%$ of the companies incorporated in Delaware and only $11 \%$ of companies incorporated in all other states. In Part III.F.1, I offer an explanation for why California firms are more likely to migrate to Delaware than firms headquartered in other states. With respect to the Daines result, this finding suggests that the higher $Q$ s reported for Delaware companies may reflect, at least in part, a mix effect rather than the benefits of Delaware incorporation. Subramanian, supra note 68 .

${ }^{93}$ This finding is consistent with Bebchuk \& Cohen, supra note 6 , at 3 , reporting that $14 \%$ of the companies in their sample are incorporated in neither their home state nor Delaware.

${ }^{94}$ See, e.g., Fisch, supra note 16, at 1062 ("Corporations choose between incorporating in their home state and incorporating in Delaware. Virtually no corporation chooses any other alternative."); Daines, supra note 14, at 547 tbl.8 ("[S]ample firms incorporate either in Delaware or their home state ...."). 


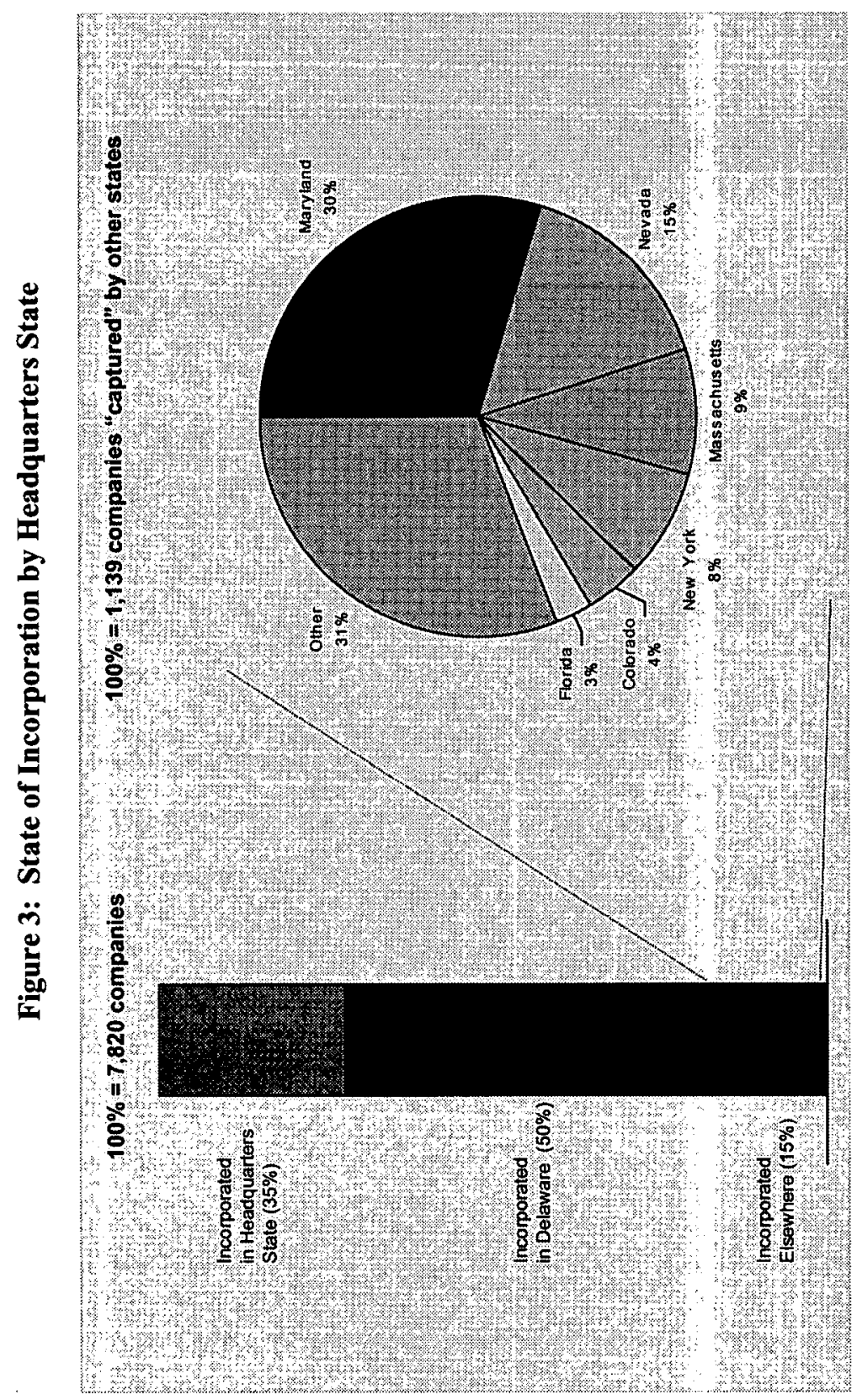


out-of-state incorporation market outside of Delaware. ${ }^{95}$

Figure 3 masks considerable variation by state. Figure 4 breaks down the incorporation decision by headquarters state among eleven major headquarters states:

Figure 4: Incorporation Choice by Headquarters State

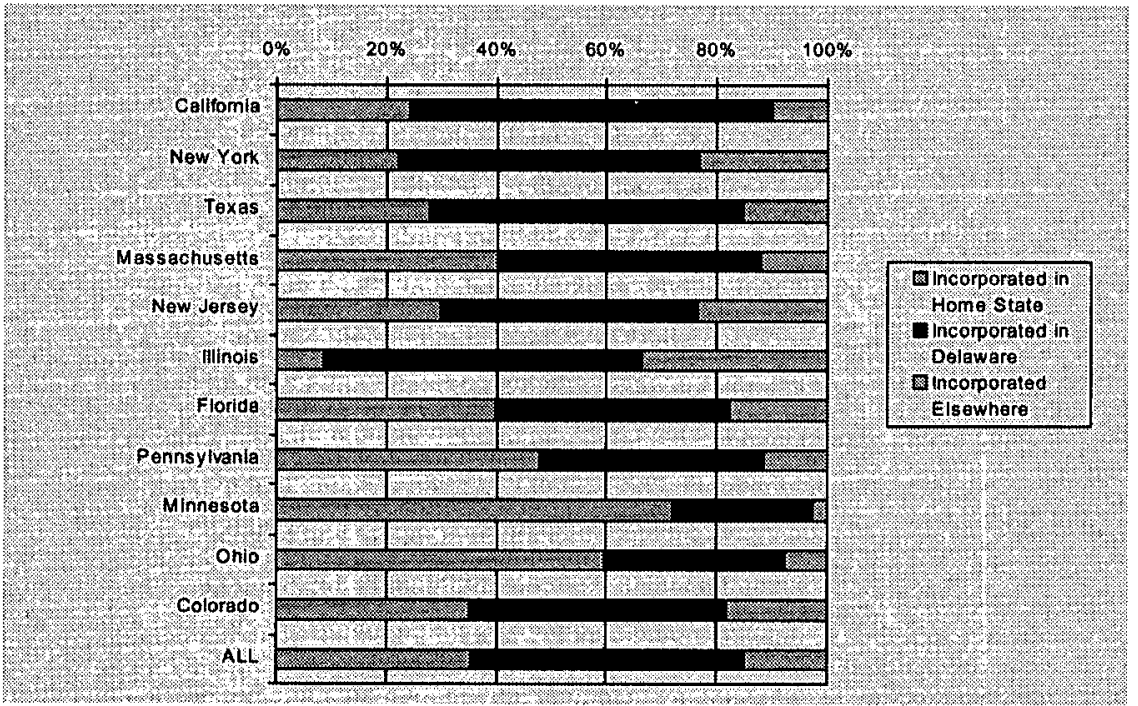

Figure 4 shows a wide range among home-state incorporation rates, from Illinois (8\%) to Minnesota $(72 \%) .^{96}$ Among the major states, California, New York, and Texas have relatively low in-state incorporation rates (as previously noted), while Massachusetts, Pennsylvania, and Florida are slightly above average. ${ }^{97}$

${ }^{95}$ As noted previously, Maryland's share comprises mostly REITs. Supra note 91. Moreover, Massachusetts' share is primarily mutual funds. Kahan \& Kamar, Myth, supra note 28, at 102. If REITs, mutual funds, and other financial companies are excluded, I find that the percentage of companies incorporated in neither their home state nor in Delaware decreases to $10 \%$, still higher than what other commentators have suggested. Financial companies are excluded from the analysis presented in infra Part III.

${ }^{96}$ Minnesota's high in-state incorporation rate is echoed in nearby northern midwestern states: Montana (75\%), Oregon (73\%), Wisconsin (72\%), and Indiana (72\%). An analysis of companies in these states suggests no distinguishable characteristics in terms of financial performance, size, or industry mix between companies in these states and companies in other states. The cause for this difference therefore remains a puzzle. $90 \%$.

Of course, the state with the highest in-state incorporation rate is Delaware, at 


\section{Nondefault Incorporation Choices}

Finally, if Delaware and home-state incorporation can in some sense be considered default choices, Figure 5 focuses on the nondefault choices that companies have made:

\section{Figure 5: Win/Lose by Headquarters State}

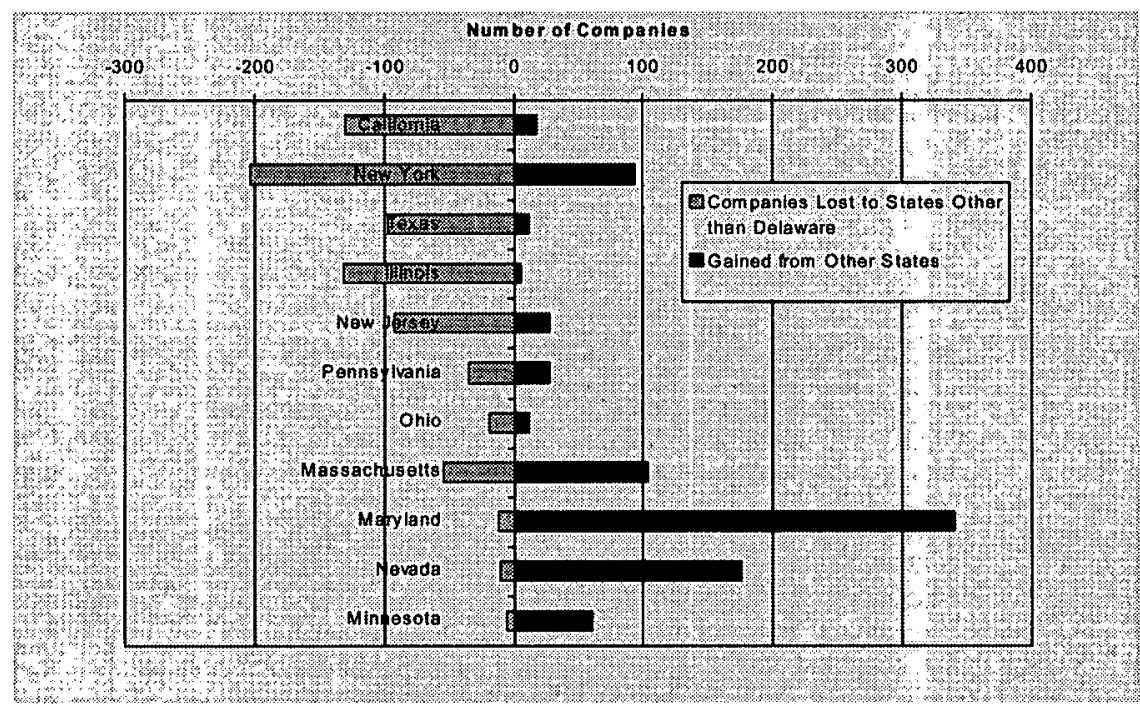

Figure 5 shows the number of companies "won" from other states, and the number of companies "lost" to other states, excluding Delaware on both sides. The logic is that losing an in-state company to Delaware does not necessarily represent a perceived inadequacy of the in-state corporate code by in-state managers, whereas losing an in-state company to some other state (Nevada, for example) does signal dissatisfaction with the in-state regime relative to the third state. Conversely, for any state other than Delaware to win an out-of-state company represents an affirmative choice by the managers of that company for the particular rules being offered by the winning state. Figure 5 thus focuses on these affirmative choices in both directions.

As in Figure 4, Figure 5 reveals wide variation among states. These variations can be grouped into three categories. At one end of the spectrum, California, New York, Texas, and Illinois are the big losers: among them they have attracted 126 companies from other states and lost 558 companies to other states, representing a net loss of 432 companies. (The magnitude of this net loss is all the more striking because it excludes migrations to and from Delaware.) On the 
other end of the spectrum, Maryland, Nevada, and Minnesota are the big winners: among them they have attracted 575 companies from other states and lost only twenty-nine companies to them, representing a net gain of 546 companies. Finally, Pennsylvania, Ohio, and Massachusetts are in the middle, gaining and losing roughly the same number of companies. ${ }^{98}$ In Parts III and IV, I develop a model of the corporate incorporation decision that attempts to explain all three of these classifications.

\section{B. Corporate Charter Flows in the $1990 \mathrm{~s}$}

\section{Reincorporations}

Part II.A examined the stock of incorporations as it existed in 2000. I now turn to an examination of the flow of reincorporations during the 1990s. While prior commentators have identified the general migration to Delaware, they have largely failed to identify where these companies are coming from. ${ }^{99}$ Table 1 shows the original state of incorporation and destination state of incorporation for 373 midstream reincorporations ${ }^{100}$ over the period 1991-2001. ${ }^{10}$

Table 1 shows that Delaware received 208 out of 373 reincorporating firms, or a $56 \%$ market share among reincorporations. This figure reflects a substantial drop compared to studies of earlier eras, which generally found an $80 \%$ to $90 \%$ reincorporation rate to Delaware. ${ }^{102}$

${ }^{98}$ Bebchuk and Cohen present data for all 50 states. Bebchuk \& Cohen, supra note 6 , at $\mathrm{A}-5$ tbl.5A.

${ }^{99}$ Cf. Daines, supra note 14, at 529 ("[T] he [reincorporation] studies generally do not distinguish between firms leaving Delaware and firms entering Delaware, but instead study all reincorporating firms.").

${ }^{100}$ Though Compustat states that its database captures only public companies, COMPUSTAT (NORTH AMERICA) USER'S GUIDE 1 (2000), available at http://www.gsb.columbia.edu/cis/research/database/compustat/COMPman.htm, Compustat sometimes includes company data, including state of incorporation, from registration documents filed in conjunction with the IPO, id. at 131 . Out of 624 reincorporations in my data set, 251 were excluded as IPO-stage reincorporations. The findings presented in this Part (including the California-to-Delaware migration) continue to hold if IPO-stage reincorporations are also included in the analysis.

${ }^{101}$ Under my definition, a midstream reincorporation occurs when a firm keeps its name but changes its state of incorporation. Reincorporations that are the result of mergers are therefore excluded. The only mergers that would be captured under my definition would be those in which the acquirer merged into the target (for tax or accounting reasons), and thus adopted the target's state of incorporation, but the merged entity kept only the acquirer's name. I know of no such instances myself and believe them to be extremely rare, if not nonexistent.

${ }^{102}$ See Dodd \& Leftwich, supra note 55, at 263 (finding that $90 \%$ of a sample of 140 


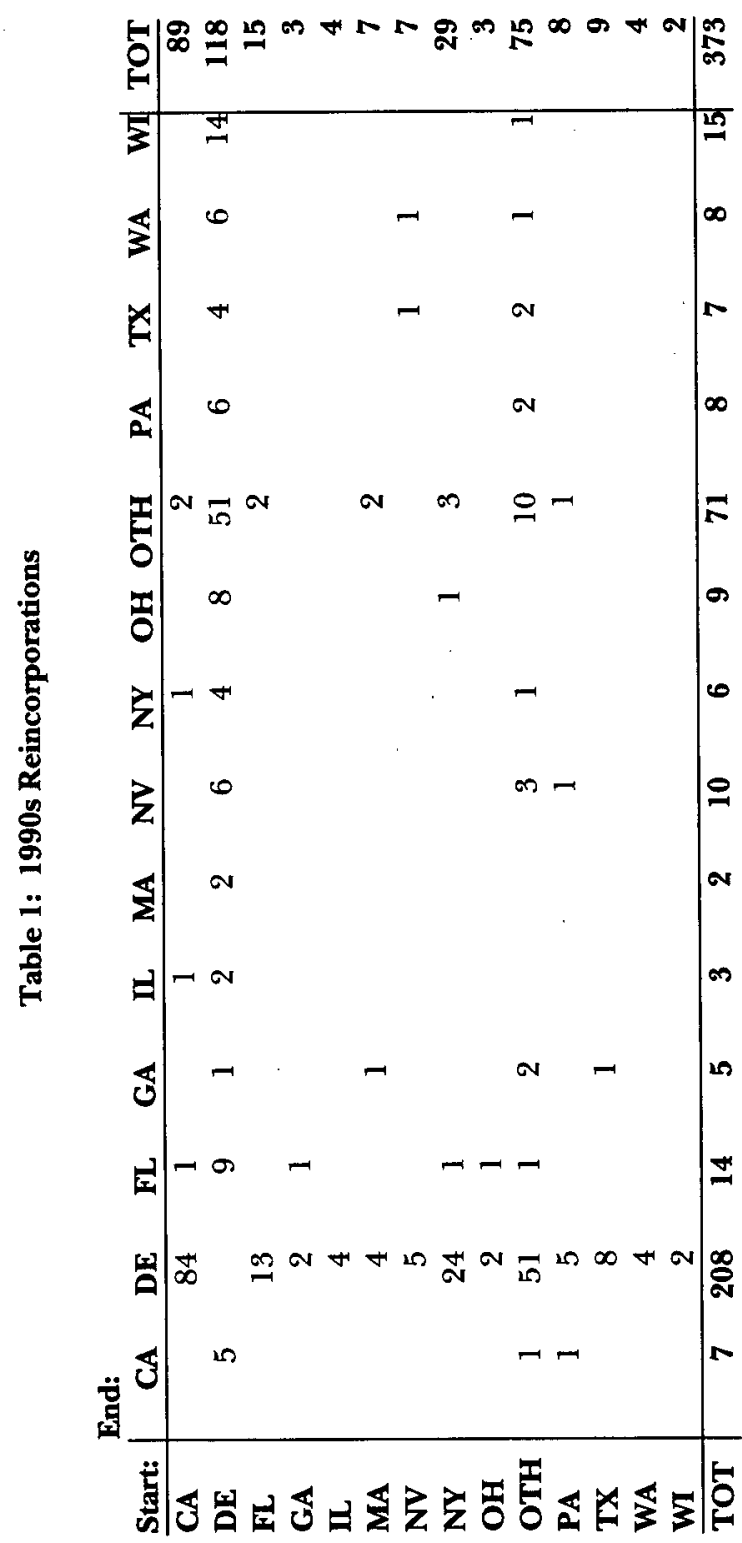

NYSE company reincorporations between 1927 and 1977 were to Delaware); Kaouris, supra note 13, at 1012 tbl.2, 1013 tbl.3 (finding that $89 \%$ of 255 OTC and $81 \%$ of 150 NYSE reincorporations between 1982 and 1994 were to Delaware); Romano, Some Pieces, supra note 4 , at 244 (finding that $82 \%$ of all reincorporating companies between 1960 and 1982 were to Delaware). My result is consistent with recent unreported work by Rob Daines: as part of his $Q$ estimate for Delaware and non-Delaware firms, he finds approximately a $65 \%$ reincorporation rate to Delaware. Telephone Interview with Robert Daines, Professor of Law, New York University (Oct. 30, 2001). 
The decline in the 1990 s might reflect a slight weakening of Delaware's dominance of the corporate charter market. Note, however, that Delaware's market share among reincorporations is still slightly higher than Delaware's share of newly incorporated companies (56\% versus $50 \%$, from Figure 2), indicating that Delaware is still gaining ground, albeit at a much slower pace, in the market for corporate charters.

Table 1 also shows that 84 reincorporations were from California to Delaware, representing $23 \%$ of total reincorporations and $40 \%$ of reincorporations to Delaware. ${ }^{103}$ In contrast, only 5 reincorporations in the sample are from Delaware to California. The California-toDelaware migration is interesting not only because California has the largest share of headquartered companies, ${ }^{104}$ but also because California has no antitakeover laws and "has long been known for its shareholder rights stance and its unwillingness to bend to corporate interests." ${ }^{105}$ I return to this comparison in Part III.F.1.

Figure 6 provides additional detail on the reincorporations reported in Table 1 by classifying reincorporating companies according to their headquarters state. Not surprisingly, Figure 6 shows that the biggest flows in the 1990s were from headquarters states to Delaware (151 reincorporations) and from Delaware back to headquarters states (93 reincorporations). These two flows account for approximately two-thirds of total reincorporations in the 1990s, indicating that one-third of reincorporations were between states other than Delaware and the company's headquarters state. This finding confirms the result presented in Part II.A, that the corporate charter market is more dynamic than the headquarters-versus-Delaware analysis that prior commentators have suggested. ${ }^{106}$

Figure 6 also sheds additional light on the California-to-Delaware migration. While Table 1 shows that $40 \%$ of total reincorporations to Delaware were from California companies, Figure 6 shows that half (76 out of 151) of all reincorporations from headquarters state to

${ }^{103}$ Among companies tracked by IRRC $(n=2,421)$, I find an even larger California-to-Delaware migration: $37 \%$ of total reincorporations in the sample (96 out of 259 ) and $51 \%$ of reincorporations to Delaware (96 out of 190) are from California to Delaware. IRRC tracks the S\&P 1500 and other companies "selected primarily on the basis of market capitalization and high institutional ownership levels." VIRGINIA ROSENBAUM, CORPORATE TAKEOVER DEFENSES, at ix (1998).

${ }^{104}$ Supra Figure 1.

${ }^{105}$ Maria Carmen S. Pinnell, State Takeover LaWS, at California-1 (2000).

${ }^{106}$ Supra Figure 3 and accompanying text. 


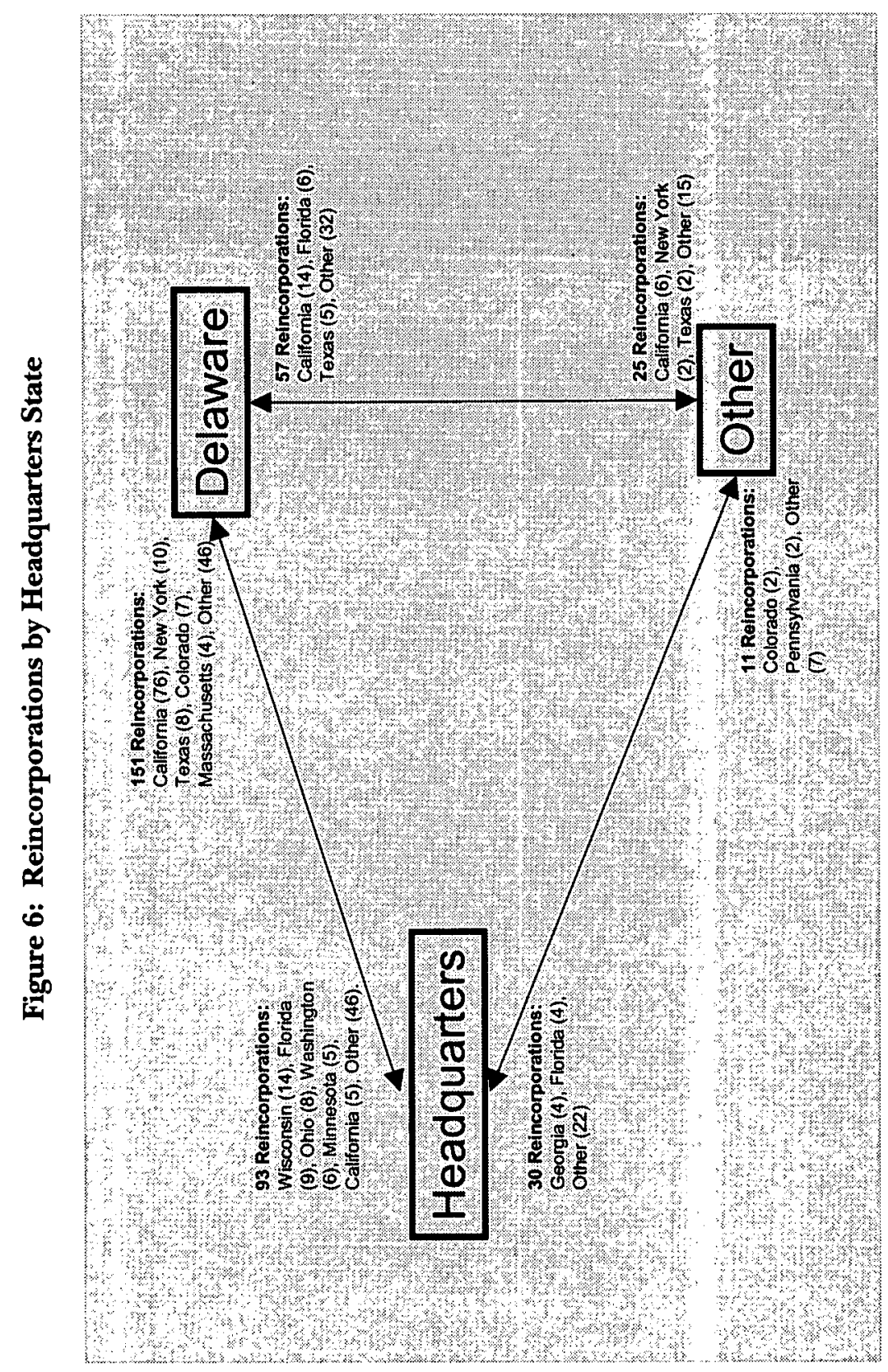


Delaware were from companies headquartered in California. Again, this statistic indicates the magnitude of the California-to-Delaware flow and suggests that the oft-cited migration to Delaware can in large part be characterized as a migration away from California.

Table 2 provides reincorporation data for the thirty-six states that were home to reincorporating companies during the 1990s:

Table 2: 1990s Reincorporations by Headquarters State

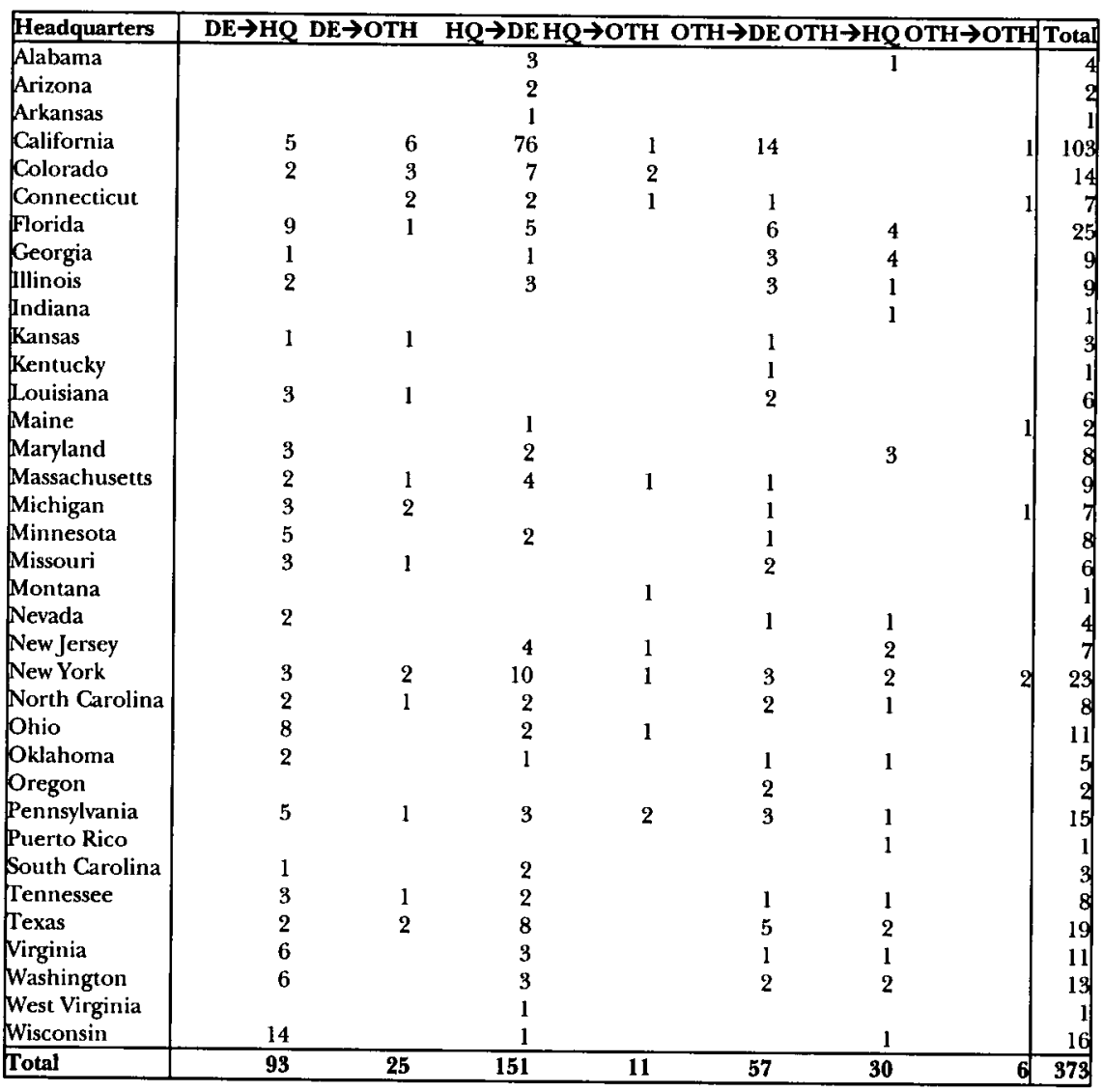

\section{IPOs}

Figure 6 and Table 2 capture only midstream reincorporations among public companies. I exclude from my analysis reincorporation decisions that occur at the IPO stage because IPO reincorporations are fundamentally different from midstream reincorporations. Reincorporations at the IPO stage do not suffer from the same potential 
agency problems as midstream reincorporations; moreover, any decisions that adversely affect shareholder value should, in theory, get priced in the IPO. ${ }^{107}$ Still, it is worthwhile to report evidence from incorporation choice at the IPO stage to determine whether Delaware is gaining or losing ground at the beginning of the pipeline. Here we find that Delaware is continuing to gain market share: examining 310 IPOs from 1994 to 1997, Daines and Klausner report a 68\% Delaware incorporation rate; ${ }^{108}$ Coates similarly reports a $62 \%$ Delaware incorporation rate among 162 companies that went public in 1991 and $1992{ }^{109}$ and Field and Karpoff report a $59 \%$ Delaware incorporation rate among their sample of IPO companies. ${ }^{110}$ Delaware, therefore, seems to be well represented at the beginning of the pipeline in addition to its dominance of the corporate charter market among mature public companies.

\section{Assessment}

To summarize, in the 1990 s Delaware sustained a dominant share of the existing corporate charter market $(50 \%)$, the reincorporation market $(56 \%)$, and the IPO charter market (approximately $60 \%$ ). Delaware's dominance is well known and has led many commentators to draw two conclusions: first, that the incorporation choice for public company managers is largely between the company's headquarters state and Delaware; and second, for reasons described in Part I, that the migration to Delaware generally represents a race to the top. ${ }^{111}$ However, two additional findings from this Part, previously unreported in the corporate charter literature, cast doubt on both of these conclusions.

${ }^{107}$ But see John C. Coates IV, Explaining Variation in Takeover Defenses: Blame the Lawyers, 89 CAL. L. REV. 1301, 1385 (2001) (suggesting that defenses may be mispriced at the IPO stage).

${ }^{108}$ Robert Daines \& Michael Klausner, Do IPO Charters Maximize Firm Value? Antitakeover Protection in IPOs, 17 J.L. ECON. \& ORG. 83, 96 tbl.2 (2001).

${ }^{109}$ Coates, supra note 107, at 1353 tbl.3.

110 Id. at 1358 n.188 (citing Laura Casares Field \& Jonathan M. Karpoff, Takeover Defenses at IPO Firms 37 tbl.3 (Oct. 27, 1999) (unpublished manuscript, on file with author)).

"II See, e.g., Daines, supra note 14, at 539 ("[T] he flow of assets into Delaware is dramatic.... This could reflect assets moving into a higher-value jurisdiction."). But see Bebchuk, Cohen, \& Ferrell, supra note 6 (manuscript at 23) ("Many scholars, without much discussion, have assumed that the presence of benefits to shareholders from Delaware incorporation would prove that state competition benefits investors. This is not a valid inference."). 
First, I find that other states have made some inroads against Delaware and seem to present a viable alternative for managers who are considering incorporating out of state. In fact, $15 \%$ of U.S. public companies are incorporated in a state other than their home state or Delaware, higher than prior commentators have either reported or assumed. In addition, one-third of all reincorporations are between states other than the headquarters state and Delaware.

Second, the conclusion that the migration to Delaware represents a race to the top ignores an important fact about where these companies are coming from. In fact, a large number of the reincorporations to Delaware are coming from California, a state with no antitakeover protections. Thus, while race-to-the-top advocates have characterized Delaware's antitakeover statute as moderate, ${ }^{112}$ the statute is, in fact, quite protective relative to the most likely alternative for many Delaware companies. ${ }^{113}$ In the next Part, I develop a general model of incorporation choice that builds from the California-to-Delaware illustration.

\section{A MODEL OF INCORPORATION CHOICE}

This Part develops a model of incorporation choice that squarely tests the empirical question implicit in the race-to-the-top/race-to-the bottom debate: Are managers able to pursue private benefits of control to the detriment of shareholders, or do market pressures align managers' interests with shareholders'? The model of incorporation choice that I develop here focuses on second-generation antitakeover statutes. Part III.A describes the approach. Part III.B describes the sample and model specification. Parts III.C and III.D present the results from the incorporation model and the reincorporation model, respectively. Part III.E assesses the evidence. Part III.F presents brief case studies of California and Nevada, which illustrate the phenomena that underlie the large-sample results.

112 E.g., Romano, Lesson, supra note 4, at 855-56.

113 See, for example, the Touchstone Software proxy statement that recommended reincorporation from California to Delaware but acknowledged that reincorporation may be disadvantageous to the extent that it has the effect of discouraging a future takeover attempt which is not approved by the Board of Directors, but which a majority of the shareholders may deem to be in their best interest or in which stockholders may receive a substantial premium for their shares over the then current market value or over their cost basis in such shares.

Touchstone Software Corp. Proxy Statement, supra note 27. 


\section{A. Methodology}

\section{The Proliferation of Antitakeover Statutes}

After the U.S. Supreme Court endorsed the jurisdictional reach of Indiana's antitakeover statute in CTS Corp. v. Dynamics Corp. of Amer$i c a,{ }^{114}$ "second-generation" antitakeover statutes rapidly proliferated across a majority of states in the late 1980s and early 1990s. Five types of statutes are the most common today. First, control share acquisition statutes prevent a bidder from voting its shares beyond a specified threshold (typically between $20 \%$ and $50 \%$ ) unless a majority of disinterested shareholders vote to allow the bidder to exercise the voting rights of its control stake. Second, business combination statutes (or "freeze-out" statutes) prevent a bidder from engaging in a wide range of transactions with an acquired company (most importantly merger, liquidation, and sale of assets), typically for either three or five years after the bidder acquires its controlling stake, unless the target board approves the acquisition. Third, "fair price" statutes, often combined with business combination statutes, set procedural criteria to determine a fair price in takeover contests. Some state statutes eliminate business combination restrictions if fair price criteria are met, and fair price criteria in turn often can be avoided if the bidder gains approval from a supermajority of disinterested shares (typically $80 \%$ ). Fourth, many states have "other constituency" statutes (also known as "constituency statutes" or "director duties" statutes), which allow the board to consider the welfare of nonshareholder constituencies (such as employees or the local community), either in the particular context of a takeover contest or more generally. Finally, many states have "pill validation" statutes, which endorse the use of a poison pill against a hostile bidder.

Table 3 lists the states that have adopted each of these statutes, along with the years that they became effective. Table 3 shows that by 2000,27 states had control share acquisition statutes, 33 had freezeout statutes, 27 had fair price statutes, 31 had constituency statutes, and 25 had pill validation statutes. ${ }^{115}$ Delaware, notably, has a business combination statute (with a three-year freeze-out period) but provides no other antitakeover protections. ${ }^{116}$

\footnotetext{
114481 U.S. 69 (1987).

115 PINNELL, supra note 105, at app. A at A-1.

116 DEL. CODE ANN. tit. 8, § 203 (2001).
} 
Table 3: State Antitakeover Statutes

\begin{tabular}{|c|c|c|c|c|c|c|}
\hline $\begin{array}{l}\text { (Year Effective) } \\
\text { State }\end{array}$ & $\begin{array}{c}\text { Constituency } \\
\text { Statute }\end{array}$ & $\begin{array}{c}\text { Control Share } \\
\text { Acquisition } \\
\text { Statute } \\
\end{array}$ & $\begin{array}{c}\text { Business } \\
\text { Combination } \\
\text { Statute } \\
\end{array}$ & $\begin{array}{c}\text { Fair Price } \\
\text { Statute } \\
\end{array}$ & $\begin{array}{c}\text { Pill Validation } \\
\text { Statute } \\
\end{array}$ & $\begin{array}{c}\text { Business } \\
\text { Combination } \\
\text { Statute (\# of } \\
\text { years) } \\
\end{array}$ \\
\hline $\begin{array}{l}\text { Alabama } \\
\text { Alaska }\end{array}$ & & & & & & \\
\hline $\begin{array}{l}\text { Arizona } \\
\text { Arkansas } \\
\text { California }\end{array}$ & 1987 & 1990 & 1987 & 1987 & . & 3 \\
\hline $\begin{array}{l}\text { California } \\
\text { Colorado }\end{array}$ & & & & & 1989 & \\
\hline $\begin{array}{l}\text { Connecticut } \\
\text { Delaware } \\
\text { District of } \\
\quad \text { Columbia }\end{array}$ & 1997 & & $\begin{array}{l}1988 \\
1987\end{array}$ & 1985 & & $\begin{array}{l}5 \\
3\end{array}$ \\
\hline Florida & 1990 & 1987 & & 1987 & 1990 & \\
\hline $\begin{array}{l}\text { Georgia } \\
\text { Hawaii }\end{array}$ & $\begin{array}{l}1989 \\
1989\end{array}$ & 1985 & 1988 & 1985 & $\begin{array}{l}1989 \\
1988\end{array}$ & 5 \\
\hline Idaho & 1988 & 1988 & 1988 & 1988 & 1988 & 3 \\
\hline Illinois & 1985 & & 1989 & 1985 & 1989 & 3 \\
\hline Indiana & 1989 & 1986 & 1986 & 1986 & 1986 & 5 \\
\hline Iowa & 1989 & & 1997 & & 1989 & 3 \\
\hline Kansas & & 1988 & 1989 & & & 3 \\
\hline Kentucky & 1989 & & 1988 & 1988 & 1984 & 5 \\
\hline Louisiana & 1988 & 1987 & & 1984 & & \\
\hline Maine & 1986 & & 1988 & & & 5 \\
\hline Maryland & 1999 & 1989 & 1989 & 1983 & 1999 & 5 \\
\hline Massachusetts & 1989 & 1987 & 1989 & & 1989 & 3 \\
\hline Michigan & & 1988 & 1984 & 1984 & & 5 \\
\hline Minnesota & 1987 & 1987 & 1987 & 1991 & & 4 \\
\hline Mississippi & 1990 & 1991 & & 1985 & & \\
\hline $\begin{array}{l}\text { Missouri } \\
\text { Montana }\end{array}$ & 1986 & 1987 & 1986 & 1986 & & 5 \\
\hline Nebraska & & 1988 & 1988 & & & 5 \\
\hline Nevada & 1991 & 1987 & 1991 & 1991 & 1989 & 3 \\
\hline $\begin{array}{l}\text { New Hamp- } \\
\text { shire }\end{array}$ & & & & & & \\
\hline New Jersey & 1989 & & 1986 & 1986 & 1989 & 5 \\
\hline New Mexico & 1987 & & & & & \\
\hline New York & 1987 & & 1985 & 1985 & 1986 & 5 \\
\hline $\begin{array}{l}\text { North Carolina } \\
\text { North Dakota }\end{array}$ & 1993 & 1987 & & 1987 & 1990 & \\
\hline Ohio & 1984 & 1982 & 1990 & 1990 & 1986 & 3 \\
\hline Oklahoma & & 1987 & 1991 & & & 3 \\
\hline Oregon & 1989 & 1987 & 1991 & & 1989 & 3 \\
\hline Pennsylvania & 1990 & 1990 & 1988 & 1988 & 1989 & 5 \\
\hline Rhode Island & 1990 & & 1990 & 1990 & 1990 & 5 \\
\hline South Carolina & & 1988 & 1988 & 1988 & & 2 \\
\hline South Dakota & 1990 & 1990 & 1990 & 1990 & 1990 & 4 \\
\hline Tennessee & 1988 & 1988 & 1988 & 1988 & 1989 & 5 \\
\hline Texas & & & 1997 & & & 3 \\
\hline $\begin{array}{l}\text { Utah } \\
\text { Vermont }\end{array}$ & 1998 & 1987 & & & 1989 & \\
\hline Virginia & & 1989 & 1988 & 1988 & 1990 & 3 \\
\hline $\begin{array}{l}\text { Washington } \\
\text { West Virginia }\end{array}$ & & & 1987 & 1987 & 1998 & 5 \\
\hline Wisconsin & 1987 & 1986 & 1987 & 1987 & 1972 & 3 \\
\hline Wyoming & 1990 & 1990 & 1989 & & & 3 \\
\hline
\end{tabular}

Source: Maria Carmen S. Pinnell, State Takeover Laws app. A (2000) 
The choice of default rule is important for antitakeover statutes because opt-in statutes require a shareholder vote in order to become effective, whereas opt-out statutes are effective unless the board proposes opting out. In fact, the vast majority of the statutes listed in Table 3 are opt-out statutes; only two statutes (Georgia's fair price statute and Tennessee's control share acquisition statute) require opting in. ${ }^{17}$ These two opt-in statutes are not particularly important for our analysis; fair price statutes seem to have had little influence on the incorporation decision, ${ }^{118}$ and Tennessee incorporations account for only $0.6 \%$ of observations in the data set. ${ }^{119}$ We also know that few companies outside of Pennsylvania, Ohio, and Massachusetts choose to opt out. ${ }^{120}$ Therefore, the statutes listed in Table 3 are effective for the vast majority of companies incorporated in those states.

Table 3 also highlights one of the attractive features of my approach, namely, the nonuniformity across states. Other commentators have noted the difficulty of empirical research on the corporate charter debate because of general uniformity in corporate law. ${ }^{121}$ In the context of antitakeover statutes, Table 3 shows twenty-one combinations of antitakeover statutes (out of thirty-two possible permutations) represented among the states today.

\section{The Wealth Effects of Antitakeover Statutes}

Many commentators have studied the stock market reaction to antitakeover statutes. These studies do not suffer from the same deficiencies as reincorporation event studies ${ }^{122}$ because antitakeover statutes typically appear in isolation, without confounding events. Instead, the primary methodological challenge for antitakeover stat-

117 GA. CODE ANN. $\S \S 14-2-1110$ to $14-2-1113$ (1999); TENN. CODE ANN. $\$ \$ 48-103-$ 301 to $48-103-312$ (1995).

${ }_{118}$ Infra Table 5, Row 4.

119 Supra Table 1.

120 Infra text accompanying notes 218-25.

121 See, e.g., Bebchuk \& Ferrell, A New Approach, supra note 6, at 140 (describing the "uniform tendency of states to provide considerable protection to incumbents"); Carney, supra note 52, at 717 (stating that American corporate law is "relatively uniform across most states"); John C. Coffee, Jr., The Future as History: The Prospects for Global Convergence in Corporate Governance and Its Implications, 93 NW. U. L. REV. 641, 702 (1999) (" $[T]$ he best documented finding in the empirical literature on the U.S. corporate chartering competition is that a high degree of uniformity has emerged in American corporate laws."); Romano, supra note 16, at 709 (finding "substantial uniformity across the states").

${ }^{122}$ See supra text accompanying notes 55-59 (discussing various reincorporation event studies). 
ute event studies is capturing the correct event window. Commentators have chosen various baseline dates: the first mention in the press, the introduction of the bill in the state legislature, the date that the bill was signed into law by the governor, or the effective date for the law. Most studies use more than one baseline date. ${ }^{123}$

Romano provides the most comprehensive review of these studies. ${ }^{124}$ She concludes from this analysis that "[e]mpirical research on the effects of takeover laws on shareholder wealth is most consistent with Cary's view of the harmful effect of state competition." ${ }^{125}$ Indeed, the weight of the evidence suggests that constituency statutes, business combination statutes, control share acquisition statutes, and pill validation statutes yield negative abnormal returns, on average, for affected companies. Fair price studies present an exception from this general trend: none of the three econometric studies that Romano surveys find abnormal returns in either direction. ${ }^{126}$

Subsequent studies confirm these basic findings. ${ }^{127}$ As a result, virtually all academic commentators on both sides of the race debate agree that state antitakeover statutes generally reduce shareholder value. ${ }^{128}$

123

See, e.g., John C. Alexander et al., Nonshareholder Constituency Statutes and Shareholder Wealth: A Note, 21 J. BANKING \& FIN. 417 (1997) (using introduction of statute and passage of statute as baseline dates); William N. Pugh \& John S. Jahera, Jr., State Antitakeover Legislation and Shareholder Wealth, 13 J. FIN. RES. 221 (1990) (examining returns around introduction of statute, passage by legislature, and approval by governor); see also Jonathan M. Karpoff \& Paul H. Malatesta, The Wealth Effects of SecondGeneration State Takeover Legislation, 25 J. Fin. ECON. 291, 308-09 tbls.3-4 (1989) (using first earliest press report as baseline date).

${ }^{124}$ See Romano, Genius, supra note 4, at 62-66 (providing an extensive table on the studies of takeover statutes).

${ }^{125}$ Id . at 60 . Importantly, some studies find negative abnormal returns only for companies that do not have firm-level defenses. See, e.g., Karpoff \& Malatesta, supra note 123, at 321 (suggesting that firm-level defenses may substitute for state antitakeover statutes). This substitution effect would only serve to weaken the results in Part III.C. The fact that I nevertheless get statistically significant results indicates the strength of the migration to state antitakeover statutes.

${ }^{126}$ See ROMANO, GENIUS, supra note 4, at 64 (finding "[n]o significant effect" in any of three fair price studies).

${ }^{127}$ See PINNELL, supra note 105, at app. C (reviewing antitakeover statute event studies through 2000). In fact, most studies of antitakeover statutes occurred in the early 1990s, coincident with the proliferation of the antitakeover statutes themselves. See supra Table 3 (showing that most of the statutes became effective in the late $1980 \mathrm{~s}$ and early 1990s). Therefore Romano's 1993 survey is more up-to-date than its timing might suggest.

${ }_{128}$ Supra note 78 and accompanying text. 


\section{Opt-Out from Antitakeover Statutes}

Despite this consensus view, opt-out from the typical antitakeover statutes is rare. Among IPO firms, Daines and Klausner report a $6 \%$ opt-out rate from the Delaware business combination statute for firms incorporating in Delaware, and a $2 \%$ opt-out rate from antitakeover statutes in other states. ${ }^{129}$ My own analysis of 2,421 firms tracked by the Investor Responsibility Research Center (IRRC) reveals an important difference between companies in states with typical antitakeover statutes and companies in Pennsylvania, Ohio, and Massachusetts. I find a 2.3\% opt-out from Delaware's business combination statute, and a 3.2\% opt-out rate from other states' antitakeover statutes, consistent with the Daines and Klausner findings for IPO companies. I also find, however, that $37 \%$ of firms (78 out of 213 ) opted out of at least some parts of the Pennsylvania, Ohio, and Massachusetts antitakeover statutes.

This finding suggests that race-to-the-top proponents cannot reasonably rely on opt-out as the mechanism that moves the race to the top in the corporate charter marketplace with respect to the typical antitakeover statutes. In fact, most companies do not opt out of these statutes. There seems to be an important difference in managers' decision making between opt-out in states with more extreme statutes (which is common) and opt-out in states with more common statutes (which is rare).

\section{Null Hypothesis}

Instead of opting out of state antitakeover statutes, companies might spur a race to the top through their movements over time. The argument is that companies that remain in heavily protected states should suffer from the negative wealth effects of antitakeover statutes. Managers of these companies will be pressured to migrate out of these states, either by the takeover market, the capital market, the product market, or some combination of these disciplining devices. The raceto-the-top view predicts that, as a result, managers will migrate away from antitakeover statutes.

The race-to-the-bottom view offers the opposite prediction. Because state antitakeover statutes "directly affect the strength of market discipline," ${ }^{\prime 130}$ the disciplining devices on which race-to-the-top propo-

\footnotetext{
129 Daines \& Klausner, supra note 108, at 96 tbl.2.

${ }^{130}$ Bebchuk, supra note 6, at 1468.
} 
nents rely will not properly influence managers' behavior. Instead, managers can pursue private benefits to the detriment of shareholders, and will migrate to antitakeover statutes rather than away from them.

These competing predictions suggest a relatively clean empirical test. The null hypothesis is that state antitakeover statutes have no impact on managers' incorporation decisions. If, instead, managers are repelled from state antitakeover statutes, this finding would support the race-to-the-top view. If managers are attracted to antitakeover statutes, this result would support the race-to-the-bottom view. ${ }^{131}$

The following Section specifies the model and describes the sample in more detail.

\section{B. Model Specification}

The basic model predicts firms' current state of incorporationclassified as either headquarters state, Delaware, or a third stateusing the antitakeover statutes of the headquarters state and other firm characteristics thought to influence the incorporation decision as independent variables. It may seem counterintuitive to determine whether firms are migrating to or away from antitakeover statutes by looking at the stock of incorporations rather than the flow of reincorporations. Note, however, that "every public company makes an explicit or implicit reincorporation decision" each year. ${ }^{132}$ Examining only the flow of reincorporations would focus on the explicit reincorporation decisions and miss the far greater number of implicit incorporation decisions that are made each year. Thus, the baseline model

${ }^{181}$ Of course, this approach relies heavily on the empirical evidence demonstrating that antitakeover statutes reduce shareholder value. It might be argued that control share acquisition statutes are, in fact, value improving because they respond to the "pressure to tender" problem identified by Bebchuk. Lucian Arye Bebchuk, Toward Undistorted Choice and Equal Treatment in Corporate Takeovers, 98 HARV. L. REV. 1695, 1696 (1985); Lucian Arye Bebchuk, The Pressure to Tender: An Analysis and a Proposed Remedy, 12 DEL. J. CORP. L. 911,911 (1987). There are two responses to this objection, one theoretical and the other empirical. First, even if control share acquisition statutes were an effective response to the pressure to tender problem, they are overly broad because they also apply to non-coercive bids. Second, as an empirical matter, the negative announcement effects summarized here are found with respect to all antitakeover statutes, including control share acquisition statutes. (This result may simply be a manifestation of the first point, that control share acquisition statutes are not narrowly targeted to address the pressure-to-tender problem.) The econometric finding on antitakeover statutes seems sufficiently robust to be able to pursue the approach outlined in the text.

${ }^{132}$ Bebchuk, supra note 6 , at 1459. 
examines the stock of incorporations as it exists in 2000. In Part III.D, I also examine the flow of reincorporations to ensure that the results are robust to this specification.

This model design minimizes a potential bias against finding a race to the bottom. Recall that shareholders must approve reincorporations, but do not need to approve remaining in the same state and cannot initiate a reincorporation themselves. ${ }^{133}$ If managers' interests are aligned with those of shareholders, as race-to-the-top theorists argue, then the shareholder vote requirement will not be a binding constraint (because shareholders will approve all reincorporation proposals on which they get to vote), and shareholder inability to initiate reincorporations will not be a problem (because managers will bring reincorporation proposals whenever shareholders would have). Thus, the background corporate law does not present an obstacle to managers migrating away from antitakeover statutes. If, on the other hand, managers' interests are not aligned with shareholders', as race-to-thebottom theorists argue, then the shareholder vote requirement becomes a binding constraint: either shareholders will reject some reincorporation proposals that managers bring, or (more likely) managers will not bring some reincorporation proposals that give them private benefits but are not in shareholders' interest. Thus, the background corporate law slows managers in their race to antitakeover statutes, which creates a bias against finding a race-to-the-bottom result. ${ }^{134}$

My specification represents a departure from prior methodologies, which focus on reincorporation flows rather than incorporation stocks. $^{135}$ In her 1985 survey of reincorporating firms, for example, Romano finds that only $16 \%$ of reincorporations between 1961 and 1983 were undertaken for antitakeover reasons. ${ }^{136}$ Putting aside the response bias problem that might undercount reincorporations un-

${ }^{139}$ See supra text accompanying note 26-27 (discussing the procedural constraints on reincorporations).

${ }^{134}$ It might be argued that this structural bias guarantees against finding a race to the bottom-why would shareholders ever approve a move to a value-decreasing state? Bebchuk offers three reasons: the move may increase shareholder value overall; shareholders may be imperfectly informed; and the move may be tied to another measure. Bebchuk, supra note 6, at 1471-75. The second reason that Bebchuk offers is in tension with his proposal for shareholder choice on the reincorporation decision. Bebchuk \& Ferrell, A New Approach, supra note 6, at 152-53.

${ }^{135}$ See, e.g., supra notes 55-56 (citing sources). In contrast to these prior studies, Bebchuk \& Cohen use a similar methodology to mine. See Bebchuk \& Cohen, supra note 6 , at 2 ("[W] hereas prior work has taken incorporation decisions as given, we seek to investigate the determinants of these incorporation decisions.").

${ }^{136}$ Romano, Some Pieces, supra note 4, at 252 tbl.4, 256 tbl.6. 
dertaken for antitakeover reasons, this approach fails to consider the far more frequent decisions that were taken by managers to remain in states that have antitakeover statutes. ${ }^{137}$ Put another way, focusing on reincorporations fully captures all pro-shareholder reincorporations but will entirely miss all pro-management non-reincorporations. ${ }^{138}$ In contrast, the specification that I have chosen will capture both sides of the reincorporation decision.

\section{Dependent Variable}

As in Part III, the sample includes all exchange-traded companies in Compustat's database of industrial firms that have their headquarters and state of incorporation in the United States. Following Daines, regulated utilities, insurance companies, banks, REITs, and other financial companies are excluded because "the corporate governance of such firms differs due to significant federal regulation."

The dependent variable INCORP is set to 0 if the firm incorporates in its home state (approximately $38 \%$ of observations); 1 if the firm incorporates in Delaware ( $52 \%$ of observations); and 2 if the firm incorporates in some other state ( $10 \%$ of observations). As noted above, this specification captures both sides of the incorporation decision that managers face: not only the affirmative choices to reincorporate, but also the passive decisions that managers make to stay in their current state.

\section{Independent Variables}

I use six dummy variables to model the antitakeover characteristics of the headquarters state. Among the typical statutes, CONSTITUENCY is set to 1 if the headquarters state has a constituency statute; CONTROL is set to 1 if the headquarters state has a control share acquisition statute; BUSCOMB is set to 1 if the headquarters state has a business combination statute; FAIR is set to 1 if the head-

${ }^{137}$ Cf. Daines, supra note 14, at 527 ("The [reincorporation] studies . . do not tell us about the effect of Delaware law on the vast majority of firms that never reincorporate after going public.").

${ }^{138}$ Bebchuk, Cohen, \& Ferrell, supra note 6 (manuscript at 24).

${ }^{139}$ Daines, supra note 14 , at 530 . This exclusion accounts for the difference between the number of companies analyzed in Part II $(n=7,820)$ and the number of companies analyzed in this Part $(n=5,852)$. See also HowELL E. JACKSON \& EDWARD L. SYMONS, JR., REGULATION OF FINANCIAL INSTITUTIONS 51-53 (1999) (describing the dual-chartering system in which banks can incorporate under either state or federal law). 
quarters state has a fair price statute; and PILL is set to 1 if the headquarters state has a pill validation statute. ${ }^{140}$

I also' include a dummy variable DISGORGESB, set to 1 if the firm has a disgorgement statute or a staggered board statute, the two types of particularly potent antitakeover statutes that cannot be adequately modeled by the other antitakeover variables in the model. ${ }^{141}$ Equivalently, DISGORGESB is set to 1 for companies headquartered in Massachusetts, Ohio, or Pennsylvania: in 1990, Ohio and Pennsylvania adopted disgorgement statutes, and Massachusetts adopted a staggered board statute. Until recently, no other state had adopted a severe antitakeover statute. ${ }^{142}$

\section{Control Variables}

I include additional independent variables to control for other

140 An alternative approach would be to compress all of the antitakeover attributes of a state into a single scalar variable. John Coates has taken this approach in developing his "Contestability Index (CI)," defined as the minimum number of days that it would take for a hostile bidder to gain control of the target's board. Coates, supra note 107, at 1388 app. B at 1389-90. Calculation of the CI often turns on the ability to act by written consent or through special meeting, combined with the ability to remove directors without cause. These features can be set by the firm in its charter or bylaws, and frequently are. As a result, examining the default terms provided by states on these issues can lead to counterintuitive results: for example, California and Massachusetts have the same CI, id. at 1409-50, even though these two states are at opposite ends of the spectrum in terms of the antitakeover protections provided, infra Parts III.F.1 \& IV.A.2. Because the CI is more appropriately calculated at the firm level than at the state level, it is less useful for the state-level analysis that I undertake here. $C f$. Coates, supra note 107, at 1409 ("Variations remain remarkably minor [among state default laws]: indices range only from forty-five to ninety, nowhere near the range found in any random sample of public companies.").

${ }^{141}$ Even though the substantive protections provided by disgorgement statutes and staggered board statutes are different, I combine them for purposes of this analysis because I argue in Part IV that they are viewed similarly by institutional investors, and collectively they are distinct from the typical antitakeover statutes. Infra Part IV.B; see also Daines, supra note 14, at 548 tbl.9 (aggregating Massachusetts, Ohio, and Pennsylvania firms for purposes of analysis). In addition, distinguishing the Massachusetts staggered board statute might capture a "Massachusetts effect" in the incorporation decision, when I am more interested in a "severe antitakeover statute effect." However, I also report results from Bebchuk \& Cohen, who disaggregate these statutes. Infra note 156 and accompanying text.

142 In June 1999, Maryland adopted a severe antitakeover statute. See Robert B. Robbins \& Dava R. Casoni, Maryland's “Just Say No" Law, INSIGHTS, Sept. 1999, at 27, 27. I consider Maryland as a separate case, infra Part V.A, because companies may have had insufficient time to react to the Maryland statute by December 2000, the cut-off point for the data (collected in June 2001). Note also that Maryland's staggered board statute is an opt-in statute, compared to Massachusetts' opt-out statute, which may create important differences between the two in practice. 
factors often thought to influence the incorporation decision. LSALE, equal to the natural log of net sales in the year 2000, is included, on the view that larger corporations are more likely to have major law firms as outside counsel, which in turn are more likely to be based in New York City, which in turn are more likely to recommend incorporation in Delaware. ${ }^{143}$ I include VLARGE, defined as net sales greater than $\$ 20$ billion, as a dummy variable, to test the hypothesis that very large corporations may remain in their home state because they have greater influence in their home state legislature than they would have in the Delaware legislature. ${ }^{144}$

I also include industry dummy variables at the two-digit SIC code level. Although some commentators have argued that Delaware caters to a particular type and size of company, ${ }^{145}$ to my knowledge no one has argued that the demand side of the corporate charter market differs meaningfully by industry. ${ }^{146}$ Nevertheless, I include industry dummies to control for the possibility that there are differences in incorporation choice by industry.

\section{Results}

\section{Single-Statute Models}

The model is run as a multinomial logistic regression. Before

${ }^{143}$ Cf. Romano, Some Pieces, supra note 4, at 274 tbl.13 (finding that $52.5 \%$ of responding firms that reincorporated report that outside counsel suggested reincorporating, indicating that outside counsel are an important source of guidance on the incorporation decision). Ideally, the model would include dummy variables for major law firms, but unfortunately no source I know of reports outside counsel for large samples of firms. In theory, outside counsel should be aligned with management (and thus subject to the same potential agency problems) because outside counsel of an acquired firm often does not stay on post-integration. See Coates, supra note 107, at 133435 tbl.1 (constructing a database including law firm identity for 180 IPO firms).

144 See 1 ARTHUr Fleischer, JR. \& Alexander R. SUSSMan, TAKEOVER Defense $4-$ 67 (6th ed. 2000) (“An influential target company may enjoy local political clout and judicial sympathy aiding its defense.").

${ }^{145}$ See, e.g., RICHARD A. POSNER \& KENNETH E. SCOTT, ECONOMICS OF CORPORATION LAW AND SECURITIES REgULATION 111 (1980) (arguing that Delaware specializes in providing corporate laws for large public corporations); Barry D. Baysinger \& Henry N. Butler, The Role of Corporate Law in the Theory of the Firm, 28 J.L. \& ECON. 179, 185-88 (1985) (arguing that a more diffuse shareholder base leads to incorporation in pro-management states such as Delaware).

${ }^{146}$ The one exception is the REIT charter market, which is dominated by Maryland. Supra note 91 and accompanying text. However, REITs and all other financial firms are excluded from the regression data set used here. Supra text accompanying note 139 . 
running the full model, I run a parsimonious model with each of the antitakeover statutes individually, in order to avoid potential multicollinearity problems arising from the fact that many states have adopted more than one of the five typical antitakeover statutes. Results from these single-statute models are reported in Table 4.

Table 4: Incorporation Choice-Single-Statute Models

\begin{tabular}{|c|c|c|c|c|c|c|}
\hline $\begin{array}{l}\text { Model \# } \rightarrow \\
\text { To Delaware: }\end{array}$ & 1 & 2 & 3 & 4 & 5 & 6 \\
\hline \multicolumn{7}{|l|}{$\begin{array}{l}\text { State Antitakeover } \\
\text { Statutes: }\end{array}$} \\
\hline Other Constituency & $\begin{array}{c}-0.32 \\
(0.06)\end{array}$ & & & & & \\
\hline Control Share Acquisition & & $\begin{array}{c}-0.89 \\
(0.06)\end{array}$ & & & & \\
\hline Business Combination & & & $\begin{array}{c}-0.31 \\
(0.06)\end{array}$ & & & \\
\hline Fair Price & & & & $\begin{array}{r}-0.43 \\
(0.06)\end{array}$ & & \\
\hline Pill Validation & & & & & $\begin{array}{c}-0.37 \\
(0.06)\end{array}$ & \\
\hline Disgorgement/SB & & & & & & $\begin{array}{r}-0.36 \\
(0.09)\end{array}$ \\
\hline \multicolumn{7}{|l|}{ Firm Characteristics: } \\
\hline Log (sales) & $\begin{array}{c}0.05 \\
(0.01)\end{array}$ & $\begin{array}{c}0.06 \\
(0.01)\end{array}$ & $\begin{array}{c}0.06 \\
(0.01)\end{array}$ & $\begin{array}{c}0.06 \\
(0.01)\end{array}$ & $\begin{array}{c}0.05 \\
(0.01)\end{array}$ & $\begin{array}{c}0.05 \\
(0.01)\end{array}$ \\
\hline Very large ( $>\$ 20$ B sales) & $\begin{array}{c}0.04 \\
(0.30)\end{array}$ & $\begin{array}{l}-0.12 \\
(0.30)\end{array}$ & $\begin{array}{c}0.06 \\
(0.30)\end{array}$ & $\begin{array}{c}0.06 \\
(0.30)\end{array}$ & $\begin{array}{c}0.04 \\
(0.30)\end{array}$ & $\begin{array}{c}0.03 \\
(0.30)\end{array}$ \\
\hline
\end{tabular}

To some other state (non-headquarters):

\begin{tabular}{|c|c|c|}
\hline \multirow{2}{*}{\multicolumn{3}{|c|}{$\begin{array}{l}\text { State Antitakeover } \\
\text { Statutes: }\end{array}$}} \\
\hline & & \\
\hline Other Constituency & $\begin{array}{l}-0.02 \\
(0.10)\end{array}$ & \\
\hline Control Share Acquisition & & $\begin{array}{r}-0.52 \\
(0.10)\end{array}$ \\
\hline Business Combination & & \\
\hline
\end{tabular}

Fair Price

0.11)

Pill Validation

$-0.11$

(0.10)

Disgorgement/SB

-0.23
$(0.10)$

$-0.59$

(0.17)

Firm Characteristics:

\begin{tabular}{|c|c|c|c|c|c|c|}
\hline Log (sales) & $\begin{array}{r}-0.14 \\
(0.02)\end{array}$ & $\begin{array}{c}-0.13 \\
(0.02)\end{array}$ & $\begin{array}{c}-0.14 \\
(0.02)\end{array}$ & $\begin{array}{c}-0.14 \\
(0.02)\end{array}$ & $\begin{array}{r}-0.14 \\
(0.02)\end{array}$ & $\begin{array}{c}-0.13 \\
(0.02)\end{array}$ \\
\hline Very large (>\$20B sales) & $\begin{array}{c}0.98 \\
(0.45)\end{array}$ & $\begin{array}{c}0.88 \\
(0.45)\end{array}$ & $\begin{array}{c}0.99 \\
(0.45)\end{array}$ & $\begin{array}{c}0.99 \\
(0.45) \\
\end{array}$ & $\begin{array}{c}0.97 \\
(0.45)\end{array}$ & $\begin{array}{r}0.94 \\
(0.45) \\
\end{array}$ \\
\hline $\begin{array}{l}\text { Pseudo R-sq } \\
\text { Log likelihood }\end{array}$ & $\begin{array}{c}4.2 \% \\
-5137.5\end{array}$ & $\begin{array}{c}6.0 \% \\
-5042.8\end{array}$ & $\begin{array}{c}4.2 \% \\
-5140.9\end{array}$ & $\begin{array}{c}4.4 \% \\
-5126.4\end{array}$ & $\begin{array}{c}4.3 \% \\
-5134.5\end{array}$ & $\begin{array}{c}4.1 \% \\
-5142.5\end{array}$ \\
\hline
\end{tabular}

Notes: All models are run as multinomial logistic regressions: $0=$ incorporation in headquarters state (baseline); $1=$ incorporation in Delaware; $2=$ incorporation in some other state. $n=5,852$ in all models. All models inchude industry dummies at the two-digit SIC code level and a constant term (not reported). Bold = significant at $95 \%$ confidence. 
The top panel reports the results from the outcome "move to Delaware" (INCORP $=1$ ), while the bottom panel reports the results from "move to some other (non-headquarters) state" (INCORP = 2). Pseudo R-sq ranging from $4.1 \%$ to $6.0 \%$ seems reasonable given the limited specification of the model. F-tests (unreported) show that all models are statistically significant at $99 \%$ confidence.

Table 4 shows that a company is far less likely to incorporate in Delaware, at $99 \%$ confidence, if its home state has an other constituency statute, a control share acquisition statute, a business combination statute, a fair price statute, a pill validation statute, or a more severe (disgorgement or staggered board) statute. All six of these models support the hypothesis that managers migrate to (or fail to migrate away from) state antitakeover statutes. In the lower panel, the results for incorporation in a third state are weaker than the Delaware results, perhaps because third states in the model are an amalgamation of more and less protective states relative to the headquarters state. Still, even here, a company is less likely to incorporate in a third state, at $95 \%$ confidence, if the company's headquarters state has a control share acquisition statute, a pill validation statute, or an extreme (disgorgement or staggered board) statute. Importantly, none of the antitakeover statute coefficients in Models \#1-6, in either the top or bottom panel, are statistically significant in a positive direction.

\section{Full Model}

Model \#1 in Table 5 shows the results from the full model, which includes all of the antitakeover statutes that were tested individually in Table 4.

The top panel of Model \#1 shows that control share acquisition statutes, business combination statutes, and pill validation statutes in the headquarters state all make Delaware incorporation less likely, consistent with the findings in Table $4 .^{147}$ This finding is also consistent with the conventional wisdom among practitioners that control share acquisition statutes and business combination statutes are the most important antitakeover statutes among the typical measures

${ }^{147}$ Bebchuk and Cohen also find that these three statutes attract more companies, consistent with the results reported here, and also find a strong timing effect (companies that went public in the 1990s are less likely to incorporate in their home state) and a geographic effect (companies located in the south and west are more likely to incorporate in-state). Bebchuk \& Cohen, supra note 6 , at A-10 tbl.10A, A-11 tbl.10B. They do not find the same "overreaching" phenomenon that I discuss in Part IV, nor do they examine reincorporations or opt-outs from antitakeover statutes. 
passed by states, and that pill validation statutes are also important "because the right to use poison pill defenses is presumably more secure when explicitly authorized by statute and is thus less likely to be limited by the courts."

\section{Table 5: Incorporation Choice—Full Model and Extensions}

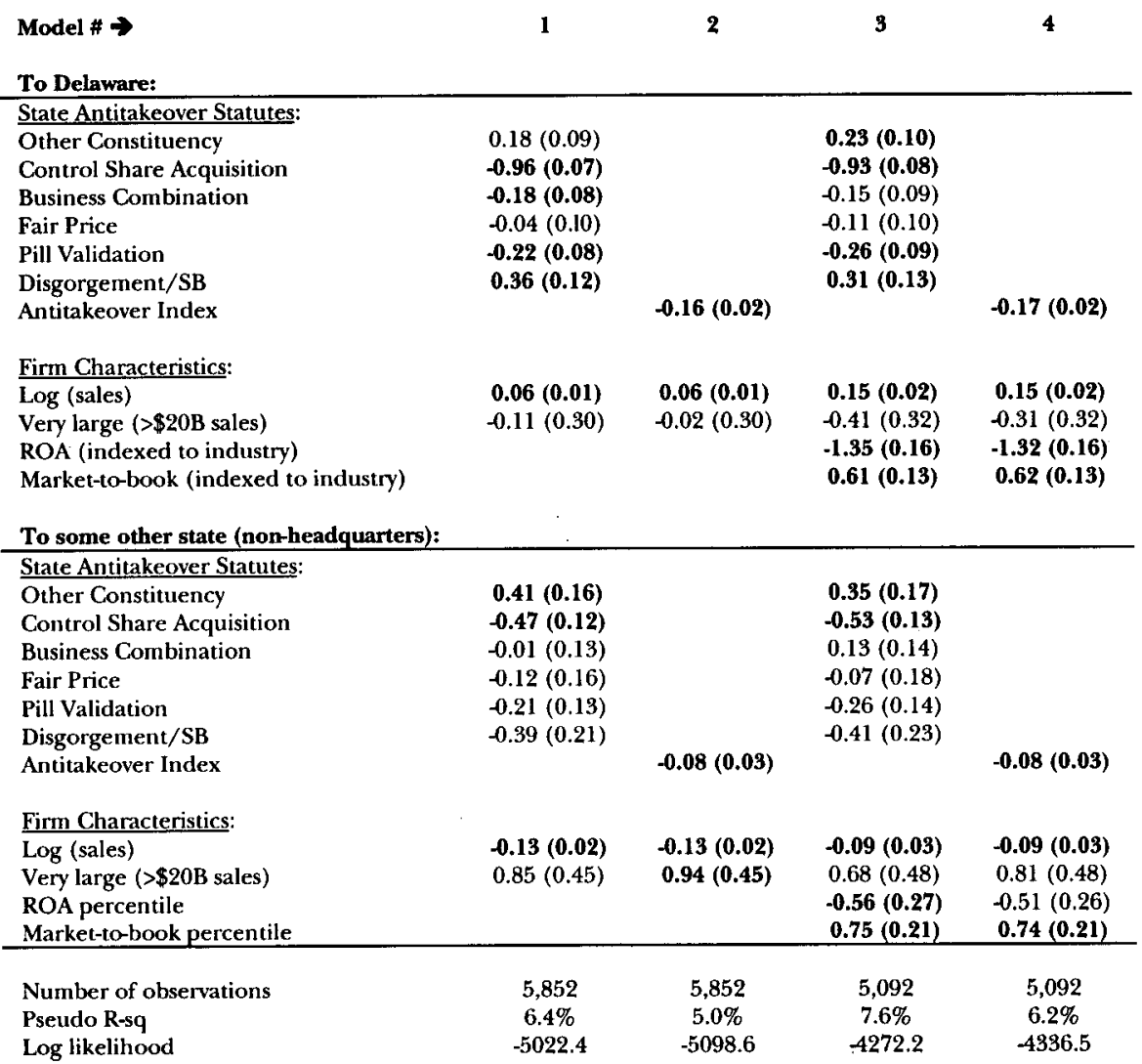

Notes: All models are run as multinomial logistic regressions: $0=$ incorporation in headquarters state (baseline); 1 = incorporation in Delaware; $2=$ incorporation in some other state. All models include industry dummies at the two-digit SIC code level and a constant term (not reported). Bold = significant at $95 \%$ confidence.

The magnitude of these coefficients is economically significant.

${ }^{148}$ Jonathan M. Karpoff \& Paul H. Malatesta, The Wealth Effects of Second-Generation State Takeover Legislation, 25 J. FIN. ECON. 291, 299 (1989); see also MARK J. ROE, STRONG MANAGERS, WEAK OWNERS: THE POLITICAL ROOTS OF AMERICAN CORPORATE FINANCE 160 (1994) ("[T] he key move probably was when states validated the poison pill, which can be a show-stopper."). 
Using the method of recycled predictions, I find that the presence of a control share acquisition statute increases the likelihood of in-state incorporation by $19 \%$; the presence of a business combination statute increases the likelihood of in-state incorporation by $3 \%$; and the presence of a pill validation statute increases the likelihood of in-state incorporation by $4 \%{ }^{149}$ These estimates are roughly additive: I find that a company headquartered in a state with all three of these statutes is $26 \%$ more likely to be incorporated in that state than a company headquartered in a state without any of these statutes.

Fair price statutes lose their significance in Table 5, suggesting that the influence of these statutes on the incorporation decision is not substantial after controlling for the influence of other more potent statutes. ${ }^{150}$ Recall that the event studies of fair price statutes were the only ones among the typical antitakeover statutes that yielded no statistically significant returns. ${ }^{151}$ Thus the one statute that does not seem to reduce shareholder value also does not influence managers' incorporation decision. ${ }^{152}$ Constituency statutes also lose their significance in the baseline model (at $95 \%$ confidence), supporting the conventional view that these statutes do not have much influence in takeover contests. ${ }^{153}$

The results for DISGORGESB (representing headquarters in Massachusetts, Ohio, or Pennsylvania) reveal the potential "overreaching" phenomenon that is discussed in more detail in the next Part. In the

${ }^{149}$ The method of recycled predictions compares the in-state incorporation rate in two hypothetical scenarios: one in which no state has the antitakeover statute of interest; and another in which every state has the antitakeover statute of interest. Without control share acquisition statutes, the in-state incorporation rate is predicted to be $\mathbf{2 6 . 0 \%}$; with them, the in-state incorporation rate is $45.0 \%$. Without business combination statutes, the in-state incorporation rate is $31.6 \%$; with them, $34.7 \%$. Without pill validation statutes, the in-state incorporation rate is $31.2 \%$; with them, $35.6 \%$.

${ }_{150}$ Cf. FLEISCHER \& SUSSMAN, supra note 144, at 4-46 ("In a world of poison pills and business combination statutes, the fair price statutes seem like vestiges of the past, but they may have some significance to certain corporations and in some circumstances.").

${ }_{151}^{15}$ Supra text accompanying note 126.

${ }^{152}$ See ROMANO, GENIUS, supra note 4, at 83 ("The optimal policy would be repeal of laws that have been found to affect stock prices adversely-control share acquisition and business combination freeze statutes.").

${ }^{153}$ See, e.g., Bishop, supra note 28, at 21 ("A number of issues are raised by Nevada's [constituency] statute, not the least of which is whether it is necessary at all."). The one exception might be Pennsylvania's constituency statute, which Conrail used successfully to defend itself from Norfolk Southern's hostile bid. For an account of the contest between CSX and Norfolk Southern to acquire Conrail, see Guhan Subramanian, A New Takeover Defense Mechanism: Using an Equal Treatment Agreement as an Alternative to the Poison Pill, 23 DEL. J. CORP. L. 375, 402-11 (1998). 
single-statute model, the coefficient for DISGORGESB is significant and negative. In the full model, however, the coefficient for DISGORGESB becomes significant and positive. Note that all three states that have severe antitakeover statutes also have constituency statutes, control share acquisition statutes, business combination statutes, and pill validation statutes. In addition, Ohio and Pennsylvania have fair price statutes, while Massachusetts does not. ${ }^{154}$ Model \#1 of Table 5 shows that after controlling for these more typical antitakeover statutes, the more potent antitakeover statutes that these states also have seem to repel companies rather than attract them.

Admittedly, the result for the extreme antitakeover statutes is more fragile than the results for the more typical antitakeover statutes. Using a different model specification that includes separate variables for disgorgement and staggered board statutes, Bebchuk and Cohen find a statistically significant positive coefficient for the staggered board statute, but not for the disgorgement statute. ${ }^{155}$ In addition, Bebchuk and Cohen report that the coefficient for the classified board statute is no longer statistically significant in their model after controlling for state characteristics. ${ }^{156}$ Neither my model nor Bebchuk and Cohen's, however, yields any evidence that the extreme antitakeover statutes attract corporations in the same way that control share acquisition statutes, business combination statutes, and pill validation statutes seem to. Moreover, the higher opt-out rates by companies in states with extreme statutes as reported in Part III.A.3 (a factor that is captured neither in my model nor in Bebchuk and Cohen's) suggest that these statutes may have revealed limits on states' abilities to entrench managers. Part IV provides a theory of antitakeover "overreaching" that describes more precisely the source of these potential limitations.

Control variables are also of interest in Model \#1. Larger companies are more likely to choose Delaware incorporation over their headquarters state, consistent with the hypothesis that outside counsel to larger firms are more likely to be from out of state and, possibly as a consequence, are more likely to recommend Delaware incorporation.

154 Supra Table 3.

${ }^{155}$ Bebchuk \& Cohen, supra note 6, at 28-29. I find the same result when I separate the two statutes: the coefficient for the classified board statute is +1.27 (SE = $0.20)$, and the coefficient for the disgorgement statute is +0.10 ( $\mathrm{SE}=0.13)$.

${ }_{156}$ Id. When I control for the same state characteristics in my model $I$ find that the classified board statute becomes borderline significant: coefficient $=+0.51$, $\mathrm{SE}=0.26$, p-value $=0.052$. 
Larger companies are also less likely to choose a third state for incorporation, also consistent with this hypothesis. Very large companies (greater than $\$ 20$ billion in sales) are not more likely to remain instate; other cut-offs for VLARGE (at $\$ 30$ billion and $\$ 15$ billion in net sales) also do not yield statistically significant results. Therefore, I am unable either to accept or to reject the political influence hypothesis from these results. ${ }^{157}$

As a first extension to the baseline model, I construct a new variable HQINDEX, which counts the number of antitakeover statutes in each state as a rough proxy for the antitakeover protections provided by the state. ${ }^{158}$ While simplistic, this approach is analogous to the "governance index" constructed in other recent work. ${ }^{159}$ I then replace the six antitakeover statute dummy variables from Model \#1 of Table 5 with a single variable HQINDEX. Model \#2 in Table 5 shows the results of this extension.

Consistent with the results from Model \#1, HQINDEX is negative and statistically significant at $99 \%$ confidence for Delaware incorporation relative to the headquarters state. This result might suggest that it is not the specific protections provided by individual antitakeover statutes, but rather the signal provided by the overall package of statutes, that attracts managers to particular states. I explore this possibility in more detail in Part III.C.3 below.

In a second extension to the basic model, I include two financial performance variables: the average market-to-book ratio ${ }^{160}$ over the

${ }^{157}$ In an interesting and important result, Bebchuk and Cohen find that large firms are more likely to incorporate in their headquarters state when their home state is small. See Bebchuk \& Cohen, supra note 6, at A-8 tbl.7 (presenting factors inducing firms to remain in state). Bebchuk and Cohen conclude from this finding that "[1]arge firms are more likely to be able to benefit from local favoritism in small states, where they can stand out and have significant clout, than in large states." Id. at 15-16.

${ }^{158}$ I thank John Coates for this suggestion. Bebchuk and Cohen adopt a similar index in their work. See id. at 23 ("Our antitakeover protection index, INDEX, attaches to each state a score from 0 to 5 that is equal to the number of standard antitakeover statutes that it has.").

${ }^{159}$ See GOMPERS, ISHII, \& METRICK, supra note 69 (constructing a governance index that counts the incidence of twenty-four firm-level takeover defense provisions for 1,500 firms tracked by the Investor Responsibility Research Center). One problem with the governance index is that firm-level defenses interact. Bebchuk, Coates, \& Subramanian, supra note 19; see also John C. Coates IV, Takeover Defenses in the Shadow of the Pill: A Critique of the Scientific Evidence, 79 TEx. L. REv. 271, 325-27 (2000) (discussing the interaction between pills and shark repellents). Interaction is not as much of an issue for state antitakeover statutes, which largely function independently of each other.

${ }^{160}$ Following Daines, I define market-to-book ratio as common shares outstanding 
period 1998-2000 and the average return-on-assets (ROAs) ${ }^{161}$ over the same period, both measured as a percentile ranking across all companies. Note that including financial performance as independent variables implies a reverse causation from Daines: ${ }^{162}$ while Daines argues that incorporation in Delaware leads to higher Tobin's $Q$, this specification tests the hypothesis that firms with better financial performance (including higher $Q$ ) might be more likely to move to Delaware or to a third state. ${ }^{163}$ Model \#3 and Model \#4 in Table 5 report the results of this extension.

Consistent with Daines, Model \#3 shows that the coefficient for market-to-book ratio is statistically significant and positive for Delaware incorporation. While Daines has suggested that this result reflects the quality of Delaware law, recent theoretical models demonstrate that it might be due to network effects and Delaware's welldeveloped legal infrastructure. ${ }^{164}$ Note, moreover, that the market-tobook coefficients in the bottom panels of both Model \#3 and Model \#4 are larger than the market-to-book coefficients in the top panel. If the causation does in fact run from corporate law to $Q$, as Daines argues, then these findings suggest that the corporate law of nonDelaware out-of-state incorporation choices provides a (slightly) larger $Q$ increment than Delaware does, which again casts doubt on the view that the migration to Delaware represents a race to the top. In current work-in-progress, I find that this effect disappears after controlling for investment opportunity and firm diversification. ${ }^{165}$ In any case, the correlation between strong performance and Delaware incorporation is ambiguous: Model \#3 and Model \#4 also show a correlation between lower ROA (not higher) and Delaware incorporation. More important for my purposes here is the point that the basic find-

multiplied by price per common share plus book value of preferred stock plus book value of debt, divided by book value of assets. See Daines, supra note 14, at 531 (discussing how market value of stock and replacement costs are determined).

${ }^{161}$ I define return-on-assets as operating income after depreciation divided by total assets of the prior year.

${ }^{162}$ See id. at 555 ("Delaware firms are worth more... [and] the results are robust to a wide variety of controls for potential endogeneity.").

${ }^{163}$ In unreported regressions, I interact categorizations of the financial performance variables with the antitakeover statutes. These interacted variables, however, are not significant in any of the models, and their inclusion does not change the other results in any meaningful way.

${ }^{164}$ Bar-Gill, Barzuza, \& Bebchuk, supra note 66.

${ }^{165}$ Subramanian, supra note 68. Controlling for other parameters, Bebchuk and Cohen also find no correlation between Delaware incorporation and Tobin's $Q$ in 1999. Bebchuk \& Cohen, supra note 6, at A-9 tbl.8. 
ings for control share acquisition statutes, pill validation statutes, business combination statutes (at $90 \%$ confidence), and the extreme statutes continue to hold after basic controls for these financial performance measures.

The one substantive difference between Model \#3 and Model \#1 is that the coefficient for constituency statutes is now statistically significant in a positive direction, i.e., firms are more likely to incorporate in Delaware when their home state has a constituency statute, after controlling for the other antitakeover measures that the state has. Constituency statutes are somewhat curious creatures in the antitakeover arena: on one hand, they seem to give directors broad discretion; ${ }^{166}$ on the other hand, econometric studies and other empirical evidence suggest that constituency statutes have had little influence on the outcomes of any control contests other than Norfolk Southern's 1997 hostile bid for Conrail in Pennsylvania. ${ }^{167}$ Therefore, the fact that they seem to repel companies after controlling for the other antitakeover statutes and basic financial performance measures remains something of a puzzle.

To summarize, the baseline model identifies three effects. First, most of the typical antitakeover statutes seem to attract (or fail to repel) managers. Second, among the typical statutes, the one that does not seem to reduce shareholder value (a fair price statute) also does not seem to influence managerial decision making on choice of incorporation. Third, the severe antitakeover statutes provided by Massachusetts, Ohio, and Pennsylvania do not seem to attract managers similarly, and, in view of the high opt-out rates from these statutes, may even repel them. I offer an "overreaching" explanation for this third result in the next Part.

\section{Timing Analysis}

One puzzle that is implicit in the analysis thus far is why antitakeover statutes should matter at all-the argument is that after the poison pill, board control is a prerequisite to gaining control of the company, but a bidder who gains control of the board can then opt out of

${ }^{166}$ See, e.g., Transcript of Record, at 642 (Nov. 19, 1996), Norfolk S. Corp. v. Conrail, Inc. (E.D. Pa. 1997) (Nos. 96-7167, 96-7350) (VanArtsdalen, J.) (holding that the Conrail board can consider "all groups that may be affected by their actions").

${ }^{167}$ See supra note 153 (discussing Pennsylvania's constituency statute in the contest between CSX and Norfolk Southern to acquire Conrail). 
virtually all antitakeover statutes. ${ }^{168}$ Therefore, the typical antitakeover statutes should have no substantive bite in the "shadow" of the poison pill. ${ }^{169}$ This theoretical argument, however, becomes weaker if the right to keep the pill is not absolute. For example, in some states, including (importantly) California, the right to keep the pill remains uncertain. ${ }^{170}$ Even in Delaware, if courts were to allow shareholders to submit bylaw proposals requiring the board to redeem the pill, ${ }^{171}$ or if courts were to cut back on the limits of the "Just Say No" defense, then its antitakeover statute might again have substantive bite. The findings documented here might be a response to the possibility that antitakeover statutes will be resuscitated in these or other ways.

Another possibility, not necessarily mutually exclusive, is that the primary influence of the antitakeover statutes on managers' incorporation choice occurred in an era when the potency of the pill had not yet been resolved. In another work, I, with others, document the evolution of the Delaware poison pill case law from the inception of the poison pill in the mid-1980s to the present. ${ }^{173}$ We show that the ability to keep the pill was not necessarily absolute until the Delaware Supreme Court's decision in Time Warmer, ${ }^{174}$ in 1989 , and subsequent illustrations of the "Just Say No" defense in hostile takeover situations such as Wallace Computer ${ }^{175}$ and Circon ${ }^{176}$ in the mid-1990s. Managers

${ }^{168}$ Coates, supra note 159 , at 321.

169 Id; see also FLEISCHER \& SUSSMAN, supra note 144, at 4-12 to 4-13 ("Although takeover statutes rarely have had a decisive effect on the outcome of takeover contests, they may afford a target more time and some negotiating leverage. ... The importance of a takeover statute recedes when the target has a poison pill ....").

${ }^{170}$ Infra Part III.F.1.

171 See Gen. DataComm Indus., Inc. v. State of Wis. Inv, Bd., 731 A.2d 818, 821 n.1 (Del. Ch. 1999) (noting open nature of this question under Delaware law). Compare Lawrence A. Hamermesh, Corporate Democracy and Stockholder-Adopted By-Laws: Taking Back the Street?, 73 TUL. L. REV. 409, 415-17 (1998) (binding shareholder bylaws not valid), with Jeffrey N. Gordon, "Just Say Never?" Poison Pills, Deadhand Pills, and Shareholder-Adopted Bylaws: An Essay for Warren Buffett, 19 CARDOzo L. REV. 511, 549 (1997) (binding shareholder bylaws should be considered valid).

${ }^{172}$ See William T. Allen, Jack B. Jacobs, \& Leo E. Strine, Jr., The Great Takeover Debate: A Meditation on Bridging the Conceptual Divide, $69 \mathrm{U}$. CHI. L. REV. (forthcoming 2002) (manuscript at 47 , on file with author), in which two current Vice-Chancellors and one former Chancellor state that " $[\mathrm{i}] \mathrm{t}$ is . . . doubtful that courts would establish a 'bright line' precedent that gives boards a carte blanche to "just say no."”

${ }_{173}$ Lucian Arye Bebchuk, John C. Coates IV, \& Guhan Subramanian, The Powerful Anti-Takeover Force of Staggered Boards: Theory, Evidence and Policy, 55 STAN. L. REv. (forthcoming 2002) (manuscript at 119-24, on file with author).

${ }^{174}$ Paramount Communications, Inc. v. Time, Inc., 571 A.2d 1140 (Del. 1989).

175 Moore v. Wallace Computer, 907 F. Supp. 1545 (D. Del. 1995).

176 See Brian Hall, Christopher J. Rose, \& Guhan Subramanian, Circon (A) 
may have responded to antitakeover statutes before the potency of the pill became apparent through the resolution of these takeover contests in the mid-1990s.

To test this hypothesis, I run the full model specified in Table 5 using 1991 incorporation choice and 1995 incorporation choice, rather than the present incorporation decision. The results are reported in Table 6 .

Table 6 shows that the influence of antitakeover statutes on incorporation choice documented in present day had largely taken hold by 1995. Model \#1 of Table 6 shows that the presence of control share acquisition statutes and pill validation statutes increased the likelihood that a company would stay in its headquarters state in 1991. Model \#2 shows that the four statutes that are statistically significant in the 2000 model - control share acquisition statutes, business combination statutes, pill validation statutes, and disgorgement/SB statutesall had the same effect as early as 1995. As a final check, I also run a panel regression using each firm-year from 1991-2000 as a separate observation. Model \#3 of Table 6 shows that these results are stronger than the 1991 model but slightly weaker than the 1995 model, perhaps reflecting the growing influence of these statutes during the 1990s.

Taken together, the results from Table 6 suggest that much of the influence of antitakeover statutes on incorporation choice had already occurred by 1995, in an era before the potency of the poison pill was widely recognized. This finding could reconcile the theoretical prediction regarding antitakeover statutes with the empirical evidence on managers' responses to them.

(Harvard Bus. Sch., Case Study No. 9-801-403, 2001). 


\section{Table 6: Incorporation Choice--Timing Analysis}

Model \# $\rightarrow \quad$ \#1 (1991 Stock) $\quad$ \#2 (1995 Stock) $\begin{gathered}\text { \# } 3 \text { (Panel Regression, } \\ 1991-2000)\end{gathered}$

To Delaware:

\begin{tabular}{|c|c|c|c|}
\hline \multicolumn{4}{|l|}{ State Antitakeover Statutes: } \\
\hline Other Constituency & $-0.03(0.12)$ & $0.04(0.10)$ & $0.05(0.08)$ \\
\hline Control Share Acquisition & $-0.69(0.08)$ & $-0.83(0.08)$ & $-0.83(0.06)$ \\
\hline Business Combination & $-0.16(0.11)$ & $-0.24(0.10)$ & $-0.13(0.07)$ \\
\hline Fair Price & $0.16(0.12)$ & $0.10(0.10)$ & $0.04(0.08)$ \\
\hline Pill Validation & $-0.34(0.10)$ & $-0.31(0.09)$ & $-0.26(0.07)$ \\
\hline Disgorgement/SB & $0.18(0.13)$ & $0.36(0.12)$ & $0.31(0.10)$ \\
\hline \multicolumn{4}{|l|}{ Firm Characteristics: } \\
\hline Log (sales) & $0.10(0.02)$ & $0.09(0.01)$ & $0.09(0.01)$ \\
\hline Very large (>\$20B sales) & $0.09(0.57)$ & $-0.27(0.50)$ & $-0.17(0.37)$ \\
\hline \multicolumn{4}{|l|}{$\begin{array}{l}\text { To some other state } \\
\text { (non-headquarters): }\end{array}$} \\
\hline \multicolumn{4}{|l|}{ State Antitakeover Statutes: } \\
\hline Other Constituency & $-0.18(0.18)$ & $-0.12(0.18)$ & $-0.02(0.13)$ \\
\hline Control Share Acquisition & $-0.50(0.14)$ & $-0.66(0.14)$ & $-0.53(0.10)$ \\
\hline Business Combination & $-0.22(0.17)$ & $-0.22(0.17)$ & $-0.07(0.10)$ \\
\hline Fair Price & $0.36(0.20)$ & $0.34(0.19)$ & $0.13(0.14)$ \\
\hline Pill Validation & $-0.35(0.16)$ & $-0.31(0.15)$ & $-0.19(0.11)$ \\
\hline Disgorgement/SB & $0.05(0.24)$ & $0.34(0.23)$ & $-0.04(0.18)$ \\
\hline \multicolumn{4}{|l|}{ Firm Characteristics: } \\
\hline Log (sales) & $-0.09(0.02)$ & $-0.09(0.02)$ & $-0.09(0.02)$ \\
\hline Very large $(>\$ 20 \mathrm{~B}$ sales $)$ & $1.47(0.75)$ & $1.29(0.65)$ & $1.21(0.47)$ \\
\hline Number of observations & 4,185 & 4,868 & 50,266 \\
\hline Pseudo R-sq & $6.0 \%$ & $6.1 \%$ & $5.4 \%$ \\
\hline Log likelihood & -3745.5 & -4224.6 & $-44,152.3$ \\
\hline
\end{tabular}

Notes: All models are run as multinomial logistic regressions: $0=$ incorporation in headquarters state (baseline); 1 = incorporation in Delaware; $2=$ incorporation in some other state. All models include industry dummies at the two-digit SIC code level and a constant term (not reported). Bold = significant at 95\% confidence. Standard errors reported in Model \#3 are robust standard errors.

In their study of the influence of antitakeover statutes on incorporation choice, Bebchuk and Cohen hypothesize that antitakeover statutes "are possibly important not only in what they actually do but also in the antitakeover message that they send and the antitakeover commitment that they communicate." This "signaling" hypothesis seems problematic because it is a signal coming from the state legislature, about what the courts might potentially do in a takeover contest. As described above, a more plausible explanation seems to be that: (1) most of the influence of antitakeover statutes on incorporation choice had already occurred by the mid-1990s, during a period when the antitakeover statutes did potentially have substantive bite; and (2) managers may continue to prefer states with antitakeover protections be-

${ }^{177}$ Bebchuk \& Cohen, supra note 6, at 23. 
cause of uncertainty regarding the potency of the pill in the future. ${ }^{178}$

To summarize this Part, my results show that managers migrate to (or fail to migrate away from) control share acquisition statutes, business combination statutes, and pill validation statutes. This finding is generally consistent with the explicit prediction of race-to-the-bottom theorists ${ }^{179}$ and inconsistent with the explicit prediction of race-to-thetop theorists. ${ }^{180}$ This finding is robust to alternative specifications of the model, including basic controls for financial performance, and does not seem to be driven by any individual state. ${ }^{181}$ However, managers do not similarly migrate to the more severe antitakeover statutes in Massachusetts, Ohio, and Pennsylvania. In the next Part, I develop an "overreaching" theory of antitakeover protection that could explain these findings. This theory would suggest limitations on the race to the bottom view.

\section{Results from Reincorporating Firms}

In the prior Section, I examined the stock of reincorporations as it existed in 1991, 1995, and (primarily) 2000. I chose this approach for the basic model instead of the more typical analysis of reincorporations in order to capture both the explicit decisions to reincorporate as well as the implicit decisions to not reincorporate. ${ }^{182}$ In fact the latter were far more numerous than the former in the 1990s. The main drawback with this approach is that it does not distinguish between a failure to migrate away from antitakeover statutes and an affirmative migration to antitakeover statutes. While both would be consistent with the theoretical prediction of the race-to-the-bottom view, most commentators would consider a proactive move to antitakeover statutes as more problematic than a (passive) failure to move away from antitakeover statutes.

In this Section, I attempt to distinguish these two stories by exam-

${ }^{178}$ I thank Marcel Kahan for helpful conversations on this point.

179 Bebchuk, supra note 6, at 1469.

${ }^{180}$ Romano, Lesson, supra note 4, at 858.

I81 In unreported regressions, I exclude companies headquartered in California, New York, Texas, and Illinois (individually and collectively) and find that the results do not change in any significant way. For example, when companies headquartered in all four states are excluded from the model, the coefficients are -0.62 ( $\mathrm{SE}=0.09$ ) for control share acquisition statutes, $-0.23(\mathrm{SE}=0.10$ ) for business combination statutes, $-0.28(\mathrm{SE}=0.09)$ for pill validation statutes, and $+0.44(\mathrm{SE}=0.12)$ for the extreme antitakeover statutes. Thus the results do not appear to be driven by the failure of these four states to adopt certain laws.

${ }^{182}$ Supra Part III.B. 
ining the flow of reincorporations for U.S. companies between 1991 and 2000. I run a Cox proportional hazards model ${ }^{183}$ to predict reincorporation during the sample period (with "reincorporation" as the failure event) as a function of: (1) the antitakeover protections provided by the company's state of incorporation; (2) the antitakeover protections provided by the company's most likely alternative state of incorporation, as defined below; and (3) other factors, already introduced in the baseline model, that are thought to influence the incorporation decision.

The most likely alternative state is defined using the following three-part rule. First, for companies incorporated in their headquarters state, the most likely alternative state is assumed to be Delaware. Second, for companies incorporated in Delaware, the most likely alternative state is assumed to be the company's headquarters state. These two definitions are consistent with Figure 6, which shows that the largest migrations during the 1990s were between Delaware and the company's headquarters state. ${ }^{184}$ Finally, for companies that were incorporated in neither their headquarters state nor in Delaware, the most likely alternative state is assumed to be Delaware. This choice is consistent with Table 2, which documents 57 reincorporations from other (non-headquarters) states to Delaware and only 36 reincorporations from other states back to the headquarters state or to some state other than Delaware. Note that the "alternative state" in the model represents the most likely alternative state, based on Figure 6 and Table 2, and not the actual state of reincorporation. The reason, of course, is that I do not have an actual state of reincorporation for the vast majority of companies that did not reincorporate during the sample period. To maintain consistency between firms that reincorporated and firms that did not, I use the same alternative state definition for both, regardless of the state that the reincorporating firms actually went to.

The results from this model are reported in Table 7:

\footnotetext{
${ }^{183}$ In unreported regressions I run the model as a logit regression and obtain similar results.

${ }^{184}$ Supra Table $2 \&$ Figure 6.
} 
Table 7: Reincorporation Choice

\begin{tabular}{|c|c|c|c|c|}
\hline Model \# $\rightarrow$ & 1 & 2 & 3 & 4 \\
\hline \multicolumn{5}{|c|}{ Current State Antitakeover Statutes: } \\
\hline Other Constituency & $0.08(0.27)$ & $-0.07(0.25)$ & $-0.07(0.27)$ & \\
\hline Control Share Acquisition & $-0.75(0.22)$ & $-0.70(0.20)$ & $-0.75(0.21)$ & \\
\hline Business Combination & $-1.61(0.20)$ & $-0.96(0.24)$ & $-0.95(0.25)$ & \\
\hline Fair Price & $0.82(0.30)$ & $0.19(0.28)$ & $0.10(0.29)$ & \\
\hline Pill Validation & $-0.30(0.21)$ & $-0.59(0.21)$ & $-0.56(0.22)$ & \\
\hline Antitakeover Index & & & & $-0.38(0.04)$ \\
\hline \multicolumn{5}{|c|}{ Alternative State Antitakeover Statutes: } \\
\hline Other Constituency & $-0.49(0.30)$ & $-0.15(0.32)$ & $-0.11(0.32)$ & \\
\hline Control Share Acquisition & $0.98(0.24)$ & $1.72(0.34)$ & $1.78(0.35)$ & \\
\hline Business Combination & $0.90(0.30)$ & $-0.06(0.32)$ & $-0.06(0.32)$ & \\
\hline Fair Price & $0.18(0.26)$ & $1.09(0.42)$ & $1.03(0.42)$ & \\
\hline Pill Validation & $-0.32(0.29)$ & $-0.03(0.30)$ & $0.04(0.31)$ & \\
\hline Antitakeover Index & & & & $0.33(0.08)$ \\
\hline \multicolumn{5}{|l|}{ Firm Characteristics: } \\
\hline $\mathrm{OH} / \mathrm{MA} / \mathrm{PA}$ headquarters? & & $-0.16(0.27)$ & $-0.22(0.28)$ & \\
\hline Delaware incorporation? & & $-3.97(0.50)$ & $-4.10(0.51)$ & $-3.50(0.30)$ \\
\hline Home state incorporation? & & $-1.27(0.18)$ & $-1.32(0.18)$ & $-1.20(0.17)$ \\
\hline Log (sales) & $0.08(0.03)$ & $0.11(0.03)$ & $0.09(0.04)$ & $0.11 \cdot(0.03)$ \\
\hline Very.large ( $\$ 20$ B sales) & $-0.85(1.03)$ & $-0.99(1.03)$ & $-1.04(1.04)$ & $-0.86(1.03)$ \\
\hline ROA percentile & & & $0.08(0.31)$ & \\
\hline Market-to-book percentile & & & $0.35(0.27)$ & \\
\hline Number of observations & 46,081 & 46,081 & 40,123 & 46,081 \\
\hline Log likelihood & -1847.5 & -1801.0 & -1667.4 & -1825.9 \\
\hline
\end{tabular}

Notes: All models are run as Cox proportional hazard regressions, in which "failure" is defined as reincorporation during the observation year (1991-2000), with multiple failures possible. All models include industry dummies at the two-digit SIC code level and a constant term (not reported). Bold = significant at $95 \%$ confidence.

The baseline specification (Model \#1) shows that incorporation in a state with a control share acquisition statute or a business combination statute made reincorporation out of the state during the 1990s substantially less likely, at $99 \%$ confidence. Conversely, the presence of these two statutes in the most likely alternative state made reincorporation substantially more likely, also at $99 \%$ confidence. These findings are consistent with the analysis of the incorporation stock in both 2000 and 1995, as reported in Tables 5 and 6 . However, in the baseline model, a fair price statute in the current state of incorporation makes reincorporation more likely, suggesting that companies may be migrating away from this statute. As noted in Part III.A.2, however, fair price statutes do not seem to have the same negative wealth effect as the other statutes do; moreover this effect seems to reverse direction in subsequent models, discussed below.

Model \#2 controls for home state incorporation, Delaware incorporation, and headquarters in Ohio, Massachusetts, or Pennsylvania. Each of these characteristics might influence the reincorporation decision independent of the actual takeover statutes that are offered. 
For example, a company that is incorporated in its home state might be less likely to reincorporate away, either for symbolic reasons, or perhaps for instrumental reasons if the company believes it has influence in the state legislature. A company that is incorporated in Delaware might reap benefits from Delaware incorporation and so might be less likely to reincorporate out of Delaware. ${ }^{185}$ Companies headquartered in Ohio, Massachusetts, and Pennsylvania also might think about reincorporation differently due to the more potent antitakeover statutes in these three states that are not captured elsewhere in the model. ${ }^{186}$

The results of this extension are shown in Model \#2 of Table 7. A control share acquisition statute, a business combination statute, and a pill validation statute in the current state of incorporation all made reincorporation less likely. This finding is consistent with the results from Table 5, which shows that the same three statutes also influence the stock of incorporations in 2000. ${ }^{187}$ The coefficients for fair price statutes are not statistically significant in Model \#2, consistent with Table 5, and confirming that managers do not seem to be influenced by the one statute that does not have negative wealth effects. The coefficient for constituency statutes is also not statistically significant, consistent with the practitioner view that these statutes are less potent and, therefore, less important as takeover defenses.

As in Model \#1, the presence of a control share acquisition statute in the alternative state makes reincorporation more likely. Size is also statistically significant in Model \#2 (and all other models), with larger companies being more likely to reincorporate. This result might be explained by standard cost-benefit analysis if reincorporation costs are relatively fixed while benefits increase with size.

Model \#2 also shows that companies incorporated in Delaware were much less likely to reincorporate, as were companies incorporated in their home state. Further work would need to be done to de-

18: See, e.g., supra note 76 (citing sources that discuss the factors that make Delaware attractive for corporations); see also Bar-Gill, Barzuza, \& Bebchuk, supra note 66, at 7 (arguing that Delaware will price below the value of these benefits in order to deter competitors from entering).

${ }^{186}$ These statutes are described in more detail in infra Parts IV.A.1 \& 2.

187 This finding is also supported by empirical work by Romano, who finds that $16 \%$ of reincorporations were motivated by antitakeover reasons, Romano, Some Pieces, supra note 4, at 252 tbl.4, 256 tbl.6, though she does not draw out the implications of her finding for the "race" debate, and this finding does not capture nonreincorporations that were motivated by antitakeover reasons. Supra text accompanying notes $136-137$. 
termine whether these findings support the theory that Delaware firms reap benefits for which they do not pay, and that firms incorporated in their headquarters have greater loyalty to those states. A plausible alternative story is that companies that have made a nonstandard choice once (i.e., by incorporating in a third state) are more likely to reincorporate again.

Model \#3 introduces basic controls for financial performance, as defined in Part III.B. Model \#3 provides no evidence that financial performance (either accounting measures or market measures) influenced the likelihood of reincorporation in the 1990s. Model \#4 aggregates the antitakeover statutes into a single "antitakeover index," as described in Part III.B, both for the current state of incorporation as well as the alternative state. This model shows that companies were less likely to reincorporate during the 1990 s for each additional antitakeover statute in their current state of incorporation. In addition, Model \#4 shows that companies were more likely to reincorporate for each additional antitakeover statute that the most likely destination state had. Interestingly, the magnitude of these two effects is approximately the same $(-0.38$ on the incumbent side and +0.33 on the destination side).

To summarize, the results presented in Table 7 provide evidence that in addition to remaining in states that had the three most important antitakeover statutes-control share acquisition statutes, business combination statutes, and pill validation statutes-companies affirmatively moved to states with these same three antitakeover statutes in the 1990s. The results in this Section are all the more striking because of the strong bias against finding a result, as described in the specification of the baseline model in Part III.B.

\section{E. Assessment}

Taken together, these results reject the null hypothesis that state antitakeover statutes have no influence on the reincorporation decision. Instead, these results support the view that managers migrate to, and fail to migrate away from, the typical antitakeover statutes that are generally acknowledged to reduce shareholder value (business combination statutes, control share acquisition statutes, and pill validation statutes). Moreover, managers seem to be less influenced, if at all, by fair price statutes, which do not seem to reduce shareholder value, and by constituency statutes, which are generally regarded to be a less potent defense. These conclusions generally support the race-to-thebottom view of competition in the corporate charter marketplace, and 
reject the specific prediction of race-to-the-top theorists that managers will migrate away from antitakeover statutes that reduce shareholder value.

One plausible objection is reverse causation: rather than companies choosing their state of incorporation in response to state antitakeover statutes, states may pass antitakeover statutes in response to companies' incorporation choices. Specifically, a state with many outof-state companies incorporated in it might be more likely to pass antitakeover statutes in order to keep these companies in-state. There are two responses to this argument. First, state statutes are generally more "sticky" than incorporation choices. While there are some examples of state statutes (and antitakeover statutes in particular) being passed in a matter of weeks or even days, ${ }^{188}$ the typical legislative approval process is time-consuming and costly. ${ }^{189}$ Choice of incorporation, in contrast, requires little effort beyond the filing of proxy materials already required in conjunction with the company's annual meeting. Thus it seems reasonable to model incorporation choice as responding to state statutes rather than vice versa. ${ }^{190}$

Second, even if state antitakeover statutes followed incorporation choice, Table 3 shows that there have been only minor changes in the states' antitakeover offerings since 1997: two states have added constituency statutes, and two other states have added pill validation statutes. Virtually all U.S. companies, therefore, have made decisions (at least three times now) on their incorporation choice in an environment in which antitakeover statutes have been almost entirely exogenously determined. To the extent that companies have stayed where they are, this represents an implicit choice in favor of the status quo, but a choice nonetheless. ${ }^{191}$ Thus even if incorporation choice and antitakeover statutes were simultaneously determined in the past, it seems reasonable to model incorporation choice in 2000 as a function of state antitakeover statutes and not vice versa.

${ }^{188}$ For example, Massachusetts' staggered board statute, requiring staggered three-year terms for directors of all companies incorporated in Massachusetts, was approved by the state legislature in one day and went into effect the very next day (Apr. 18, 1990). PinNelL, supra note 105, at Massachusetts-5.

${ }^{189}$ For example, Connecticut passed its five-year freeze-out law in June 1988 after "months of public discussion and debate." Id.

${ }^{190}$ Roberta Romano develops a model to predict adoption of state antitakeover statutes, but does not include variables suggested by the discussion here, such as percent of in-state incorporations or percent of out-of-state incorporations. Roberta Romano, The Political Economy of Takeover Statutes, 73 VA. L. REV. 111, 142-45 (1987).

${ }^{191}$ Bebchuk, supra note 6 , at 1459 . 


\section{F. Case Studies}

\section{California}

Two case studies provide some texture to the large-sample results presented so far. First, California is an important state to understand in the corporate charter marketplace, not only for its size, but also for its poor showing in the market for corporate charters. California is the headquarters of more corporations than any other state ( $16 \%$ by number and $11 \%$ by sales), yet it has only $4 \%$ of the corporate charter market by number and $1 \%$ by sales. ${ }^{192}$ Mostly it has lost these companies to Delaware: during the 1990s, 84 companies shifted their state of incorporation from California to Delaware (and only five went the other way), so that by 2000 a full two-thirds of companies headquartered in California were incorporated in Delaware. This is one of the highest Delaware incorporation rates among all the states, and much higher than the national average of $50 \%$.

California is not only losing to Delaware: in 2000, 128 companies headquartered in California were not incorporated in California or Delaware, but in some third state. In contrast, only 18 companies chose California incorporation over their own home state and Delaware. California's market share of the corporate charter market has declined from $5 \%$ to $4 \%$ in the 1990 s and may continue to decline in the future. ${ }^{193}$

Why is California such a poor player in this market? As described by the IRRC, "California has long been known for its shareholder rights stance and its unwillingness to bend to corporate interests." ${ }^{194}$ California has no antitakeover statutes, a feature that it shares with only six other states-Alabama, Alaska, Arkansas, Montana, New Hampshire, and West Virginia-which collectively are home to 124 companies but state of incorporation for only 39 of them. In 1988,

\footnotetext{
${ }^{192}$ See also Bebchuk \& Cohen, supra note 6, at 27 ("California ... retains only $23 \%$ of the firms located in it.").

${ }^{199}$ Cf. Keith Paul Bishop, Other Views: Businesses Prefer Nevada and Delaware for Incorporation, SACRAMENTO BEE, Nov. 30, 2001 ("Why are Delaware and Nevada eating our lunch? Because their legislatures recognize that businesses have a choice and they have designed corporate laws that reflect an appropriate balance. California has not.").

194 PINNELL, supra note 105, at California-1; see also CONSTANCE E. BAgley, LeGAL ASPECTS OF ENTREPRENEURSHIP: A CONCEPTUAL FRAMEWORK 11 (Harvard Bus. Sch. Case Study No. N9-802-161, Jan. 29, 2002) (“Some jurisdictions, such as Delaware, are generally viewed as being pro-management. Others, such as California, are more protective of shareholders, especially minority shareholders.").
} 
the California Senate Commission on Corporate Governance, Shareholder Rights, and Securities Transactions reviewed the state's takeover regime and made a number of pro-shareholder recommendations. The California legislature quickly acted on these recommendations and approved bills that provided for disclosure of proxy voting records, restricted the use of supermajority voting requirements, required an independent fairness opinion in management buyouts, and restricted the payment of greenmail. Governor Deukmejian signed all the proposals into law except the antigreenmail provision, on the view that greenmail was "'an essentially interstate market phenomenon" and thus better regulated at the federal level. ${ }^{\text {i95 }}$

In 1989, California went further by amending its corporate code to require directors to act not only in "the best interest of the corporation," but also (explicitly) in the best interest of "its shareholders." The additional language, essentially amounting to an "anticonstituency" provision, received substantial attention from California business lawyers at the time ${ }^{197}$ and illustrates the extent of California's pro-shareholder leanings.

Finally, and perhaps most importantly, California has not validated the "flip-in" poison pill, which is the most common version of the pill today. ${ }^{198}$ The leading treatise on California corporate law suggests that such a pill "appears to be violative" of section 203 of the California Corporate Code, which prohibits distinctions among shareholders. ${ }^{199}$ Table 1 shows that eighty-nine companies have migrated away from California and seven companies have migrated into California since these laws were enacted.

${ }^{195}$ PINNELL, supra note 105, at California-2.

196 See CAL. CORP. CODE. $\$ 309$ (a) (West 1990) ("A director shall perform the duties of a director ... in a manner such director believes to be in the best interests of the corporation and its shareholders....").

${ }^{197}$ Interview with Constance E. Bagley, Associate Professor, Harvard Business School, in Boston, Mass. (Nov. 2, 2001). Professor Bagley was a corporate partner at McCutchen, Doyle, Brown \& Enersen in San Francisco at the time this law was enacted.

${ }^{198}$ HAROLD MARSH, JR,, R. ROY FINKLE, \& I.ARRY W. SONSINI, MARSH'S CALIFORNIA CORPORATION LAW \$ 2.05[F], at 2-50 (4th ed. 2001).

${ }^{199}$ Id.; see also E-mail from Keith Paul Bishop, Commissioner of Corporations in California from 1996 to 1997, to Guhan Subramanian (Feb. 5, 2002) (on file with author) ("Because pills discriminate against holders, [Section 203] would seem to be a problem."). 


\section{Nevada}

In contrast, Nevada has been a successful, if small, player in the corporate charter marketplace. In 2000 , only $0.8 \%$ of companies had their headquarters in Nevada, but $2.8 \%$ of U.S. companies are incorporated there. (With 217 incorporations, Nevada has more than twothirds of California's 331 incorporations.) More strikingly, Nevada has $15 \%$ of the non-Delaware out-of-state incorporations market, second only to Maryland. One hundred seventy-five companies chose Nevada incorporation over their own home state and over Delaware, compared to only eleven companies headquartered in Nevada which choose a third state over Nevada and Delaware.

What explains Nevada's relative success? The state has had a control share acquisition statute since 1987 (one of the earliest), ${ }^{200}$ a pill validation statute since $1989,{ }^{201}$ a constituency statute since $1991,{ }^{202}$ and a business combination statute with a three-year freeze-out provision since $1991 .{ }^{203}$ Only eight states provide the same array of protections as Nevada: Idaho, Indiana, Maryland, Ohio, Pennsylvania, South Dakota, Tennessee, and Wisconsin. Moreover, Nevada's director liability statute does not mention any particular standard of care, ${ }^{204}$ "suggest[ing] that a director of a Nevada corporation can be grossly negligent and still meet the standard of care." ${ }^{205}$ Nevada provides extremely broad director indemnification provisions, allowing companies to eliminate or limit the personal liability of directors and officers for breach of fiduciary duty. ${ }^{206}$ Finally, Nevada has extremely limited disclosure requirements: Nevada corporations are not required to publicly disclose the dates and times of annual shareholder and director meetings, the number of shares issued and outstanding, or the identity of its shareholders, all of which could make a hostile takeover bid more difficult. ${ }^{207}$

\footnotetext{
${ }^{200}$ NEV. REV. STAT. ANN. $\$ \$ 78.378-78.379(3)$ (Michie 1999).

${ }^{201} I d . \$ \S 78.195(5), 78.350(3), \& 78.378(3)$

${ }^{202} I d . \$ 78.138(3)-(4)$. Unlike many states' statutes, Nevada's constituency statute applies generally, not just in the change of control context. Id.

Id. $\$ \$ 78.411-78.444$.

${ }^{204}$ See id. $\$ 78.138(1)$ (stating that directors "shall exercise their powers in good faith and with a view to the interests of the corporation").

${ }^{205}$ Bishop, supra note 28, at 20.

${ }^{206}$ NeV. ReV. Stat. ANN. $\$ 78.037$ (1) (Michie 1999); cf. DEL. Code ANN. tit. 8, $\$ 102(b)(7)$ (2001) (prohibiting limitations on director liability for breach of duty of loyalty, for "acts or omissions not in good faith," or for "any transaction from which the director derived an improper impersonal benefit").

${ }^{207}$ Leland J. Reicher \& Kari H. Endries, Comporations Don't Always Come Out Ahead in
} 
Taken together, the case studies of California and Nevada provide anecdotal evidence in support of the general result reported in this Part. The general proposition is that companies tend to migrate away from states such as California, which have few antitakeover protections, and toward states such as Nevada, which have greater antitakeover protections. In view of the robust econometric evidence that antitakeover statutes reduce shareholder value, these results support the race-to-the-bottom view. In the next Part, however, I discuss an important qualification to this general finding that suggests some limits on the states' overall race to the bottom.

\section{ANTITAKEOVER "OVERREACHING"}

I now return to the puzzle identified in Part III.C: After controlling for the typical antitakeover statutes, the extreme antitakeover statutes in Massachusetts, Ohio, and Pennsylvania do not seem to attract companies. In addition, companies that remain in Massachusetts, Ohio, and Pennsylvania are far more likely to opt out from at least some portion of these states' antitakeover statutes. ${ }^{208}$ In this Part, I develop a model of antitakeover "overreaching" that explains these phenomena. The results suggest a more nuanced view of the race debate than has been developed in the literature to date.

Part IV.A describes the Massachusetts, Ohio, and Pennsylvania antitakeover statutes in more detail. Part IV.B presents an overreaching theory to explain the large-sample results.

\section{A. Description of Severe Antitakeover Statutes}

\section{Pennsylvania and Ohio}

Pennsylvania and Ohio are the only two states with "disgorgement" (or "recapture of profits") statutes. These statutes require bidders to disgorge short-term profits from failed bid attempts and thus prevent bidders from recouping their bid costs through the usual toehold/greenmail route. ${ }^{209}$ Pennsylvania adopted its law in response to a hostile tender offer from Canada's Belzberg family for Armstrong World Industries, a Pennsylvania corporation. The bill was intro-

\footnotetext{
Nevada, L.A. BUS. J., May 1, 2000, at 32.

208 Supra Part III.A.3.

209 OHIO REv. Code ANN. $\$ 1707.043$ (Anderson 2001); 15 PA. CONS. STAT. ANN. $\S \S$ 2571-75 (West 1995).
} 
duced in the Pennsylvania legislature in October 1989, in response to Belzberg's initial posturing, and became effective on April 27, $1990 .{ }^{210}$ The Pennsylvania statute allows the corporation to recover any profits from shares sold by the bidder between twenty-four months before and eighteen months after becoming a "controlling person" of the company (defined as acquiring or announcing an intent to acquire $20 \%$ voting control). ${ }^{211}$

Ohio passed its disgorgement statute along with other antitakeover measures on April 11, 1990. The Ohio statute, unlike the Pennsylvania statute, only applies to stock sold by the bidder within eighteen months after the announcement of the bid. ${ }^{212}$ Virtually all commentators agree that these two "innovative" ${ }^{\text {"19 }}$ statutes are far more potent than the more typical antitakeover statutes that other states have passed. ${ }^{214}$

Most of the econometric analysis has focused on the Pennsylvania statute, perhaps because it was introduced earlier, even though the Ohio disgorgement statute actually went into effect first (by two weeks). ${ }^{215}$ All of these studies have found large and statistically significant negative wealth effects during the proposal and adoption of the statute, ranging from $2.5 \%$ to $9.1 \%$, with an average loss of $6.0 \%{ }^{216}$

210 For a summary of the enormous investor and editorial criticism of the statute, see PINNELL, supra note 105, at Pennsylvania-5 to -7 .

211 PA. Cons. STAT. ANN. \$ 2575(1)-(2) (West 1995).

212 OHIO REv. CODE ANN. $\$ 1707.043$ (A), (E)(1) (Anderson 2001). The bidder may gain exemption from the statute by demonstrating to the court that the profits did not exceed $\$ 250,000$. Id.

${ }^{219}$ Mark E. Crain, Comment, Disgorgement of Greenmail Profits: Examining a New Weapon in State Anti-Takeover Arsenals, 28 Hous. L. REV. 867, 869 (1991).

${ }^{214}$ See, e.g., Steven M.H. Wallman \& Liran A. Gordon, Pennsylvania's Anti-Raider Legislation, INSIGHTS, Aug. 1990, at 38, 38 (stating that the Pennsylvania antitakeover statute "has been characterized by the media as the nation's toughest anti-raider legislation").

${ }^{215}$ PINNELL, supra note 105, at Ohio-4.

216 See sources cited in PINNELL, supra note 105, at app. C: Donald MargotTA, Stock Price Effects of Pennsylvania ACT 36 (Northeastern Univ., Working Paper, 1991) (finding a 5.5\% decline); P.R. Chandy et al., The Shareholder Wealth Effects of the Pennsylvania Fourth Generation Antitakeover Law, 32 AM. BUS. L.J. 399, 433 (1995) (2.5\% decline); Jonathan M. Karpoff \& Paul H. Malatesta, Pennsylvania Law: State Antitakeover Laws and Stock Prices, 46 FIN. ANALYSIS J. 8 (1990) (5.8\% decline); Stephen L. Nesbitt, The Impact of Antitakeover Legislation on Pennsylvania Common Stock Prices, WILSHIRE ASSOCIATES, Apr. 23, 1990 (4\% decline); L. Mick Swartz, The 1990 Pennsylvania Antitakeover Law: Should Firms Opt Out of Antitakeover Legislation?, $11 \mathrm{~J}$. ACCT., AUDITING \& FIN. 223 (1996) (9.0\% decline); Samuel H. Szewczyk \& George P. Tsetsekos, State Intervention in the Market for Comporate Control: The Case of Pennsyluania Senate Bill 1310, $31 \mathrm{~J}$. FIN. ECON. 3 (1992) (9.1\% decline). 
Both Pennsylvania and Ohio permit corporations to opt out of these statutes, ${ }^{217}$ and to varying degrees, companies in both states have. Romano reports that $64 \%$ of identified firms (127 out of 199) opted out either completely or partially from the Pennsylvania antitakeover statute. ${ }^{218}$ From my sample of 2,421 firms tracked by the IRRC, I similarly found that 59\% of Pennsylvania companies (44 out of 74) opted out in some way. For Ohio, I found that $11 \%$ of companies (9 out of 80) opted out of at least some aspects of the statute, higher than the $2-6 \%$ opt-out rate for Delaware companies, ${ }^{219}$ but substantially lower than the Pennsylvania opt-out rate. This difference may be due to the fact that Pennsylvania companies could only opt out in the first ninety days after the statute went into effect; ${ }^{220}$ in contrast, boards can opt out from the Ohio statute at any time.

\section{Massachusetts}

On April 17, 1990 (within days of the effective date of both the Pennsylvania and Ohio statutes), Massachusetts adopted legislation requiring most Massachusetts corporations to have staggered boards of directors, with one-third of the directors being elected each year. ${ }^{221}$ The statute was adopted after BTR, a British industrial manufacturer, announced an unsolicited tender offer and a proxy fight for Norton Company. While all states allow staggered boards, ${ }^{222}$ Massachusetts is the only state that provides this defense via statute. In other work, I with others show that an "effective" staggered board, when combined with a poison pill, is a very potent defense against a potential hostile bidder. ${ }^{223}$ Thus, the Massachusetts statute provides a powerful mechanism for board entrenchment.

217 OHIO Rev. CODE ANN. $§ 1707.043$ (Anderson 2001); 15 PA. CONS. STAT. ANN. § 2571(b) (2) (West 1995).

${ }^{218}$ Seventeen percent opted out completely; another $25 \%$ opted out of certain provisions; and only $23 \%$ did not opt out at all (another $35 \%$ were unidentified). Romano, Lesson, supra note 4, at 859 tbl. 1.

${ }^{219}$ Supra text accompanying note 129.

${ }_{220} 15$ PA. CONS. STAT. ANN. § 2571(b) (2) (West 1995); see also Jason Shargel, Opting Out of the New Pennsylvania Anti-Takeover Law, INSIGHTS, July 1990, at 29, 29 ("Once this 90 day opt out period expires, it will never be available (even with shareholder approval) again, and the corporation will be frozen into the new Act's provisions ....").

${ }^{221}$ MASs. ANN. LAWS ch. 156B, \$ 50A (Law. Co-op. 1996).

${ }^{222}$ See, e.g., DEL. CODE ANN. tit. 8, \$141(d) (2001) (outlining the organization of directors); MODEL BUS. CORP. ACT $§ 8.06$ (1984) (discussing staggered terms for directors).

${ }^{223}$ Bebchuk, Coates, \& Subramanian, supra note 173, at 119. 
Two studies have examined the wealth effects of the Massachusetts staggered board antitakeover statute: Swartz finds a remarkable $16 \%$ decrease in shareholder value for Massachusetts firms that did not previously have takeover defenses; ${ }^{224}$ Daines finds a more moderate but still statistically significant $2 \%$ drop in value ${ }^{225}$ Companies could opt out from the Massachusetts statute either through board vote or through a two-thirds vote by shareholders. In my IRRC sample described above, $42 \%$ of Massachusetts companies ( 25 out of 59) opted out of at least some aspects of the statute.

\section{B. A Theory of Antitakeover Overreaching ${ }^{226}$}

The previous Section demonstrates that managers' responses to the severe antitakeover statutes in Ohio, Pennsylvania, and Massachusetts are different from their responses to the more typical antitakeover statutes: I find no evidence that companies migrate to the extreme statutes in the same way that they migrate to some of the typical statutes; moreover, companies in states with extreme statutes opt out from these statutes at a higher rate than companies in other states.

Prior empirical analyses have failed to explain (or recognize) this difference between the typical antitakeover statutes and the three severe statutes. In this Section, I offer a theory that explains this difference, drawing from Bebchuk's distinction between "significantly distributive" ${ }^{, 227}$ and "insignificantly distributive" ${ }^{2228}$ corporate law rules.

\section{Distributive Element of Severe Antitakeover Statutes}

Bebchuk examines both the benefit to the manager (the "distribu-

\footnotetext{
${ }^{225}$ Robert Daines, Do Staggered Boards Affect Firm Value? Massachusetts and the Market for Corporate Control (2001) (unpublished manuscript, on file with author).

${ }^{226}$ To my knowledge no one has previously used the term "antitakeover overreaching," though David Charny suggested something similar in 1991. See David Charny, Competition Among Jurisdictions in Formulating Corporate Law Rules: An American Perspective on the "Race to the Bottom" in the European Communities, 32 HARV. INT'L L.J. 423, 446 (1991) ("[V]arious constraints would prevent managers from flocking to reincorporate [to states whose laws were] ... egregiously permissive ...."). Bebchuk made a similar prediction in 1992. Infra note 238.

${ }^{227}$ Bebchuk defines "significantly distributive" issues as issues in which "the distributive element is significant relative to the efficiency element." Bebchuk, supra note 6 , at 1461 .

${ }^{228}$ Bebchuk defines "insignificantly distributive" issues as issues in which "the distributive element is very small relative to the efficiency element." Id.
} (1998).

${ }_{224}$ L. Mick Swartz, The Massachusetts Classified Board Law, 22 J. ECON. \& FIN. 29 
tive element") and the cost to shareholders (the "efficiency element"). On the first, it is clear that the severe antitakeover statutes provide a benefit to disloyal managers in the form of increased entrenchment and the opportunity for extracting larger private benefits of control. The Massachusetts, Ohio, and Pennsylvania statutes have substantive bite because they provide protection from the takeover market that companies cannot achieve on their own. This fact would suggest that the distributive element is large.

However, the increased voice of institutional investors during the $1990 \mathrm{~s}^{229}$ and the resulting improvements in corporate governance ${ }^{230}$ may have reduced the benefit that managers derive from the severe statutes. The reason is that migrating to one of the states with a severe statute sends an adverse signal to the marketplace in a way that migrating to the more typical statutes does not. For companies not headquartered in Massachusetts, Ohio, or Pennsylvania, reincorporating to these states would create a presumption among shareholders that the move is being made for antitakeover reasons. In contrast, reincorporation to states with other, more typical (and hence less prominent) antitakeover statutes (e.g., Delaware or Nevada) could be justified using non-takeover-related reasons, even if, as demonstrated in this Article, takeover concerns seem to motivate many incorporation and reincorporation decisions.

It would be exceedingly difficult for managers to get shareholder approval for moving to Massachusetts, Ohio, or Pennsylvania, unless the move were packaged with other proposals that, in total, increased shareholder value. ${ }^{231}$ Managers, therefore, will be reluctant to bring such proposals to shareholders in view of the low likelihood of success. ${ }^{232}$ The few managers who bring such proposals and are successful in reincorporating to these states would suffer personally from the an-

${ }^{229}$ See Roberta Romano, Less Is More: Making Institutional Investor Activism a Valuable Mechanism of Corporate Governance, 18 YALE J. ON REG. 174, 175-76 (2001) (documenting the rise of institutional investors in monitoring activities since 1986).

${ }^{230}$ See Daniel P. Hann, Emerging Issues in U.S. Corporate Governance: Are the Recent Reforms Working?, 68 DEF. COUNS. J. 191, 205 (2001) (stating that "in some instances" institutional investors have "improved information, enhanced accountability, and probably helped to correct certain abuses"); see also Romano, supra note 229, at 177 (noting that improved corporate governance has not led to noticeable improvements in corporate performance, and proposing ways to achieve this connection).

${ }^{29}$ Bebchuk, supra note 6, at 1475 .

232 See BRUCE WASSERSTEIN, BIG DEAL 712-13 (1998) ("A wholesale defensive strategy is also available-reincorporating in a state with laws more favorable to takeover defense. ... [However, r] eincorporation should be pursued only if a company expects to win the necessary shareholder approval."). 
titakeover presumption, either through increased likelihood of termination or through increased monitoring by investors wary of the move. Netting these costs against the benefits of increased entrenchment may make the distributive element relatively small for the severe antitakeover statutes compared to the distributive element for the more typical antitakeover statutes. ${ }^{293}$

\section{Efficiency Element of Severe Antitakeover Statutes}

Moving to the second part of Bebchuk's analysis, the econometric evidence suggests that the cost to shareholders of the severe antitakeover statutes may be greater than the cost to shareholders of the typical antitakeover statutes. While studies of both types of statutes generally find that they reduce shareholder value, studies of the typical statutes generally find a 2-3\% decline in shareholder wealth, compared to an average $6 \%$ decline for studies assessing the Pennsylvania statute $^{234}$ and an average $9 \%$ decline for studies assessing the Massachusetts statute. ${ }^{235}$ These results are consistent with a qualitative assessment of the two types of statutes: while the typical antitakeover statutes may have (at most) mild substantive bite for most companies, the severe antitakeover statutes substantially shut down the market for corporate control as a disciplining device. The difference in estimated shareholder wealth effects may be reflecting this fact. Thus, it seems reasonable to believe that the (negative) efficiency element for the severe antitakeover statutes is larger than the (also negative) efficiency element for the more typical statutes.

\section{Assessment}

If, as argued above, the distributive element is smaller and the efficiency element is larger for the severe antitakeover statutes relative to the more typical antitakeover statutes, then it might be the case that the severe antitakeover statutes are insignificantly redistributive relative to the typical statutes. ${ }^{236}$ Bebchuk argues that "market discipline will probably discourage managers from seeking inefficient rules with

${ }^{233}$ Note that the costs of the reincorporation need not outweigh the benefits in order to make the move unlikely; rather, they need to make the benefits "insignificant" relative to the costs to shareholders. Bebchuk, supra note 6 , at 1464.

${ }^{234}$ See supra note 216 (citing sources).

${ }^{235}$ See supra notes 224-25 (citing sources).

${ }^{236}$ Note that accepting either the distributive element story or the efficiency element story is sufficient to reach this conclusion. 
respect to insignificantly redistributive issues, [though] it is unlikely to have such an effect with respect to significantly redistributive issues."237 Applying this theoretical prediction to the context of the antitakeover statutes, managers should migrate to the "significantly redistributive" typical antitakeover statutes and not migrate to the "insignificantly redistributive" severe antitakeover statutes. ${ }^{238}$ Of course, this is precisely the effect I report from the large-sample evidence in Part III.

Note that the market discipline that I depend on cannot come from the market for corporate control, because the severe antitakeover statutes effectively cut this off as a disciplining device. ${ }^{239}$ Instead, the more likely disciplining device is the managerial labor market: managers who migrate to states with severe antitakeover statutes will suffer a private loss from the increased likelihood of termination. In fact the empirical evidence suggests that this market has been quite vibrant in the 1990s, and therefore reliance on it as a disciplining device is not unfounded. ${ }^{240}$

This overreaching theory suggests that states, in their effort to attract corporate charter business, must be careful to craft antitakeover statutes that are significantly redistributive rather than insignificantly redistributive. Put differently, statutes that excessively entrench managers, and do so in an atypical way, may actually repel companies rather than attract them. Thus, states such as Massachusetts, Ohio, and Pennsylvania may have overreached in the corporate charter marketplace.

Georgia may in fact provide a negative example of this overreaching theory. In 1997, the Georgia legislature rejected a mandatory staggered board statute similar to the Massachusetts statute, on the grounds that it would make Georgia corporations less attractive to in-

237

Bebchuk, supra note 6 , at 1462 . With significantly redistributive issues, the private benefits to managers outweigh managers' interest in promoting shareholder welfare. With insignificantly redistributive issues, the reverse is true. See id. at 1462-63 (discussing the inverse relationship between redistributive issues and private benefits to managers).

${ }^{238}$ Bebchuk makes the same prediction less formally. See id. at 1468 ("[C]onsider a rule that makes a takeover virtually impossible. Such a rule may reduce the value of a large company by two billion dollars while providing the managers with extra security worth only twenty million dollars.").

${ }^{239}$ Cf. id. at 1470 ("[B] ecause [antitakeover] rules weaken the disciplinary force of the market for corporate control, market discipline can hardly be relied on to discourage managers from seeking these rules.").

240 See Rakesh Khurana, Transitions at the Top: CeO Position as Open \& Closed to Competition 23 (Harvard Bus. Sch., Working Paper, 2001) (describing the effect of the market as a tool for disciplining and removing management). 
vestors. ${ }^{241}$ While at least one commentator views this as evidence in support of the race-to-the-top view (i.e., away from antitakeover statutes), ${ }^{242}$ my analysis suggests that this race-to-the-top exists only among the extreme antitakeover statutes. In the next Part, I review a state that made the opposite decision from Georgia.

\section{IMPLICATIONS}

The results presented in this Article have important implications for the most recent development in the U.S. corporate charter marketplace, the Maryland Unsolicited Takeover Act of 1999. ${ }^{243}$ More broadly, my findings have implications for takeover regulation in the United States and for the emerging charter competition in the European Union. Each of these issues is discussed in greater detail in the remainder of this Part.

\section{A. The Maryland Unsolicited Takeover Act of 1999}

The Maryland Unsolicited Takeover Act (MUTA) was signed into law on June 1, 1999. It contains an array of potent takeover defenses: for example, a broad constituency provision, which allows directors to reject a takeover bid because of the effect that the acquisition would have on nonshareholder constituencies; ${ }^{244}$ and a pill validation provision, which codifies common law endorsement of the pill in Maryland, ${ }^{245}$ but then goes further to allow continuing director (slow-hand) pills. ${ }^{246}$ MUTA also rejects Delaware's heightened scrutiny for director

${ }^{241}$ Carney, supra note 52, at 756. Although this incident has not received much attention in the race debate, Professor Carney's account is based on his own firsthand experience participating in the legislative process. Id. at $756 \mathrm{n} .153$.

${ }^{242} I d$. at 756.

24\$ MD. CODE. ANN., CORPS. \& ASS'NS $\$ \$ 3-801$ to 3-805 (1999).

${ }^{244} I d$. at $\$ \S 2-104$ (b) (9), 2-405.1(d) (5) (ii) (1997).

245 See Realty Acquisition v. Prop. Trust of Am., Fed. Sec. L. Rep. (CCH) I 95,245 (Md. 1989) (upholding a shareholder rights plan under Maryland corporate law).

${ }^{246}$ MD. CODE ANN., CORPS. \& ASs'NS $\$ 2-201$ (c) (2) (ii) (Supp. 2001) (allowing directors to limit the power of future directors to vote for redemption, modification, or termination of shareholder rights plans for up to 180 days). In contrast, Delaware has rejected slow-hand and dead-hand poison pills. See Quickturn Design Sys., Inc. v. Shapiro, 721 A.2d 1281 (Del. 1998) (invalidating slow-hand pill); Carmody v. Toll Bros., Inc., 723 A.2d 1180, 1195 (Del. Ch. 1998) (allowing a claim challenging a dead-hand pill to survive summary judgment); see also Bank of New York Co. v. Irving Bank Corp., 528 N.Y.S.2d 482, 485-86 (Sup. Ct. 1988) (invalidating a dead-hand pill under New York law). But see AMP Inc. v. Allied Signal Inc., No. 98-4405, 1998 U.S. Dist. LEXIS 15617, at *34-35 (E.D. Pa. Oct. 8, 1998) (upholding slow-hand pill under Pennsylvania corporate law), rev'd sub nom. AMP Inc. v. Allied Signal Corp., 168 F.3d 649 (3d Cir. 
conduct in sale of control situations ${ }^{247}$ and instead provides that directors' actions will be assessed under the business judgment rule and "may not be subject to a higher duty or greater scrutiny than is applied to any other act of a director. ${ }^{248}$ In effect this provision extends the "Just Say No" defense that Delaware courts have permitted for strategic, stock-for-stock mergers ${ }^{249}$ to all sale of control situations in Maryland.

Finally, the Maryland statute allows Maryland corporations to adopt a staggered board without shareholder approval, and even if contrary to the firm's charter. ${ }^{250}$ MUTA also provides collateral provisions that make the staggered board "effective," a hostile bidder from dismantling the board by soliciting written consents or by calling a special meeting. ${ }^{252}$ Instead, a hostile bidder must wait through two annual meetings, which can take as long as two years, ${ }^{253}$ in order to gain control of the board and then take control of the company. ${ }^{254}$

1999); Invacare Corp. v. Healthdyne Techs., 968 F. Supp. 1578, 1580-81 (N.D. Ga. 1997) (upholding dead-hand pill under Georgia corporate law).

${ }^{247}$ Unocal Corp. v. Mesa Petroleum Co., 493 A.2d 946 (Del. 1985).

248 MD. CODE. ANN., CORPS. \& ASs'NS § 2-405.1 (f) (1999).

249 See Paramount Communications, Inc. v. Time, Inc., 571 A.2d 1140, 1154 (Del. 1989) ("Directors are not obliged to abandon a deliberately conceived corporate plan for a short-term shareholder profit unless there is clearly no basis to sustain the corporate strategy."). For a federal district court opinion that appears to broaden "Just Say No" beyond the strategic merger context, see Moore Corp. Ltd. v. Wallace Computer Servs., Inc., 907 F. Supp. 1545, 1553-64 (D. Del. 1995).

${ }^{250}$ MD. CODE ANN., CORPS. \& Ass'ns § 3-803 (1999 \& Supp. 2001).

251 If directors adopt a staggered board under MUTA, directors may be removed only for cause and with the vote of at least two-thirds of shareholders, id. \$3-804(a) (Supp. 2001), the number of directors may only be determined by the board, id. $\S 3-804$ (b), vacancies on the board can only be filled by current directors, id. $\S 3-804$ (c) (2), and special meetings can only be called on the written request of a majority of shareholders, id. $\$ 3-805$ (1) (1999). All of these provisions apply even if contrary to the charter or bylaws of the company. Id. $\$ 3-802$ (a) (2) (ii), (d) (3). In addition, Maryland corporate law does not permit shareholder action through written consent.

${ }^{252}$ See John C. Coates IV, Measuring the Domain of Mediating Hierarchy: How Contestable Are U.S. Public Corporations?, 24 J. CORP. L. 837, 854 \& n.95 (1999) (describing the development of poison pills and classified boards); Bebchuk, Coates, \& Subramanian, supra note 19 (documenting the interactions among takeover defenses that are required to construct an "effective" staggered board).

${ }^{253}$ See, e.g., HALL, ROSE, \& SubRAMANIAN, supra note 176 (documenting U.S. Surgical's hostile bid against Circon's effective staggered board, which remained outstanding for almost two years and two annual shareholder meetings before being withdrawn).

${ }^{254}$ For empirical evidence on the difficulty of this route, see Bebchuk, Coates, \& Subramanian, supra note 173. 
Unsurprisingly, institutional investors and shareholder activists have criticized MUTA. ${ }^{255}$ Academic commentators have yet to acknowledge MUTA in the "race" debate-for example, there have not yet been any event studies examining the shareholder wealth impact of MUTA. Clearly, race-to-the-top proponents will have difficulty reconciling their view with this statute, by far the most severe among second-generation antitakeover statutes. The overreaching theory presented here, however, suggests that MUTA might be ineffective in attracting companies to Maryland.

\section{B. Takeover Regulation in the United States}

Beyond Maryland, the results presented here also have implications for the broader question of takeover regulation in the United States. The typical policy proposal from race-to-the-bottom proponents has been increased federalization of corporate law. ${ }^{256}$ Recently, Lucian Bebchuk and Allen Ferrell have proposed a variation on this solution, a "federal choice-enhancing intervention," which would provide a body of federal takeover law and a mandatory process rule allowing shareholders to opt-in to this federal regime. ${ }^{25}$

The statistics and case studies presented in this Article suggest that the federal regime is not the critical aspect of the Bebchuk and Ferrell proposal. ${ }^{258}$ The shareholder-friendly takeover environment that they envision being provided by the federal government is already provided in large part by California. ${ }^{259}$ While Bebchuk and Ferrell describe the basic asymmetry favoring targets in state corporate law (because state law regulates in-state companies as targets but not as

255 PINNELL, supra note 105, at Maryland-4.

256 See, e.g., NADER, GREEN, \& SELIGMAN, supra note 9, at 62-71 (arguing that federal chartering is compelling because state chartering "is a costly anachronism"); Cary, supra note 5, at 701-02 (proposing a Federal Corporate Uniformity Act to apply to all corporations with over $\$ 1$ million of assets and 300 shareholders).

${ }^{2.57}$ Bebchuk \& Ferrell, A New Approach, supra note 6, at 143-49; see also Bratton \& McCahery, supra note 53, at 1926 (proposing, more generally, "a federally mandated privilege of direct shareholder access to amend the corporate charter at the annual meeting of shareholders").

${ }^{258}$ While Bebchuk and Ferrell agree that " $[\mathrm{t}]$ he addition of a mandatory federal process rule would by itself be a significant improvement," $i d$. at 154, they argue that the federal choice is also important because the federal government "would be a different type of player with different incentives from the typical state," id. at 151. In this Part, I build on the work of prior commentators who argue that the incentives in fact are not that different at the federal level.

${ }^{259}$ Supra Part III.F.1. 
acquirers), ${ }^{260}$ they fail to identify California's apparent ability to resist these antitakeover forces. ${ }^{261}$ It is possible that a federal takeover regime would go further than California-for example, adopting the British City Code's sweeping prohibition on "any action" made without shareholder approval that could frustrate a takeover attempt (which would, most importantly, severely restrict the ability for a target board to use a pill). However, it seems unlikely that the federal government would go so far, because the reasons that political processes favor targets would continue to exist at the federal level. A common argument, put forward most forcefully by Romano, is that the beneficiaries of antitakeover legislation (managers and employees) are a concentrated group, while the group bearing the costs of such legislation (shareholders) is diffuse. ${ }^{262}$ As just one manifestation of this point, Romano reports that $18 \%$ of witnesses at congressional hearings on takeover legislation from 1963 to 1987 were target managers, compared to only $6 \%$ of witnesses who were takeover bidders. ${ }^{263}$ Perhaps as a result of this imbalance, Romano finds an "overwhelmingly one-sided (antibidder) aspect of bills that have persistently been on Congress's agenda over the years." ${ }^{264}$

It is possible that the rise of institutional investors in the 1990s would solve the diffusion problem that Romano identifies. However, in other work, I, with George Baker, provide evidence on the global market for corporate control suggesting another antitakeover tilt, one that would exist even more at the federal level than at the state level. While the increasing globalization of the M\&A marketplace is wellknown, ${ }^{265}$ and the fact that the largest cross-border flows are between North America (basically the United States) and the European Union is perhaps equally unsurprising, we find that these flows are distinctly one-way: during the 1990s takeover wave, European companies bought American companies at a far greater rate than American com-

${ }^{260}$ Bebchuk \& Ferrell, A New Approach, supra note 6, at 134-35.

261 See id. at 140 (analyzing the "persistent and uniform tendency of states to provide consideráble protection to incumbents"); $i d$. at 151 (describing incentives to provide "substantial antitakeover protections as do all the states currently").

${ }^{262}$ ROMANO, GENIUS, supra note 4 , at 75.

263 See id. at 77 tbl.4-3 (reporting that out of a total of 255 witnesses at congressional hearings, 46 were target managers and 15 were takeover bidders).

264 Id. at 80.

${ }^{265}$ See, e.g., Bernard S. Black, The First International Merger Wave (and the Fifth and Last U.S. Wave), 54 U. MiAmI L. REV. 799, 800-01 (2000) (presenting evidence that recent takeover activity can fairly be categorized as the first international wave of mergers and acquisitions). 
panies bought European companies. European acquisitions of American companies amounted to almost $\$ 700$ billion in the 1990 s (22\% of total acquisitions by European acquirers and $13 \%$ of total acquisitions of North American targets), compared to approximately $\$ 250$ billion in American acquisitions of European companies $6 \%$ of total acquisitions by North American acquirers and $10 \%$ of total acquisitions of European targets). ${ }^{266}$ Fourteen of the twenty-five largest cross-continent M\&A deals involved U.S. targets; only three involved U.S. acquirers. ${ }^{267}$ If the political forces that are responsible (at least in part) for these flows persist in the future, the trends that we report for the 1990s takeover wave would continue, and targets' interests would be represented more than bidders' interests in a hypothetical federal regime.

Thus, I am less optimistic than Bebchuk and Ferrell in the ability of the federal government to provide a more pro-takeover regime than California currently provides. However, the second prong of their proposal-a mandatory process rule allowing shareholders choice on the incorporation decision-responds precisely to the deficiency in corporate charter competition identified in this Article. Note that the problem is primarily (though not exclusively) a problem of omission: managers are failing to bring proposals to either opt out or reincorporate away from states that pass antitakeover statutes. Bebchuk and Ferrell's mandatory process rule would release shareholders from managers' agenda-setting power on incorporation choice, and possibly could trigger a wave of reincorporations toward more takeover-friendly regimes.

In Bebchuk and Ferrell's proposal, the only alternative to management's chosen state of incorporation is the federal regime, ${ }^{268}$ which

${ }^{266}$ George P. Baker \& Guhan Subramanian, The Global Market for Corporate Control (unpublished data, on file with author). Though the vast majority of these deals were friendly, takeover defenses are nevertheless relevant because friendly deals are often negotiated in the "shadow" of a hostile bid. Cf. G. William Schwert, Hostility in Takeovers: In the Eyes of the Beholder?, 55 J. FIN. 2599, 2638 (2000) (finding that friendly deals are not distinguishable from hostile deals along standard economic measures); Robert H. Mnookin \& Lewis Kornhauser, Bargaining in the Shadow of the Law: The Case of Divorce, 88 YALE L.J. 950, 951 (1979) (demonstrating how the "shadow of the law" provides endowments that influence outcomes in the divorce context).

${ }^{267}$ Baker \& Subramanian, supra note 266.

${ }^{268}$ This point is not completely clear. Compare Bebchuk \& Ferrell, A New Approach, supra note 6 , at 147 ("[C] $[\mathrm{Coice-enhancing} \mathrm{intervention} \mathrm{includes} \mathrm{a} \mathrm{mandatory} \mathrm{vote} \mathrm{pro-}$ cedure by which shareholders can choose to have their corporation governed by the federal takeover rules rather than that of their corporation's state of incorporation."), with id. at 162-63 ("[T] he federal process rule would establish a process by which com- 
(as argued above) is unlikely to provide a more pro-takeover environment than California currently provides. Because a reasonably full spectrum already exists among the U.S. states, I propose that choice should be broadened to allow shareholders to opt in to any state, effectively putting incorporation decisions in shareholders' hands rather than in managers' hands. The desirable feature of this modest modification is that it eliminates the need for federal intervention beyond the imposition of the mandatory choice rule. The drawback is that it maintains (and arguably broadens) shareholder encroachment on a decision that has traditionally been entrusted to the board. ${ }^{269}$ It is not clear from Bebchuk and Ferrell's analysis what makes the reincorporation decision different from other board decisions that are potentially "significantly redistributive." Viewed in this way, their proposal becomes quite radical, for it begins a shift in the conventional allocation of powers between shareholders and the board in a way that has no clear limits. While Oklahoma and Georgia have addressed this issue in a related context, ${ }^{270}$ the fundamental policy questions that are implicit in the Bebchuk and Ferrell proposal are still outstanding in Delaware and in all other states. ${ }^{271}$

\section{Regulatory Competition in the European Union}

Finally, the results presented in this Article have implications for the regulatory competition debate within the European Union (EU). To date, competition for corporate charters in the EU has been extremely limited, for three reasons. First, a number of EU countries endorse the "real seat" doctrine, which requires companies to be in-

panies could switch from one state to another and, in particular, would make it possible for shareholders to initiate and approve such switches...."). Overall, Bebchuk and Ferrell seem to be describing a binary choice between current state regime and the federal regime, $i d$. at $113,115-16,156$, which suggests that my approach would be a (minor) modification to their proposal.

${ }^{269}$ CLARK, supra note 27, at 105-06. Choi and Guzman offer a similar critique. Stephen J. Choi \& Andrew T. Guzman, Choice and Federal Intervention in Corporate Law, 87 VA. L. REV. 961 (2001).

${ }_{270} \mathrm{See}$ Int'l Bhd. of Teamsters v. Fleming Cos., 1999 OK 3, II 22, 975 P.2d 907, 912 (holding that shareholders may propose bylaws amendment to redeem the pill, provided that the certificate of incorporation does not provide otherwise); Invacare Corp. v. Healthdyne Techs., 968 F. Supp. 1578, 1582 (N.D. Ga. 1997) (concluding that plaintiff's proposed bylaw "would infringe upon the board's discretion by requiring the incumbent ... board to remove the continuing director provision").

${ }_{271}$ See, e.g., Geoffrey Colvin, Shareholders of the World: Sue!, FORTUNE, Mar. 19, 2001, at 50 ("Who's really in charge of your company? ... The amazing fact is that the answer to this question ... is a big muddle."). 
corporated where they have their headquarters (in contrast to the U.S.-style "incorporation theory" doctrine). ${ }^{272}$ Second, reincorporations are typically treated as liquidations of the company, which trigger tax recognition on appreciated assets. ${ }^{273}$ Third, while EU countries impose initial incorporation fees, they do not impose annual taxes, which should in theory reduce the incentive for countries to compete for midstream corporate charters. ${ }^{274}$

However, two recent developments may open the door for U.S.style charter competition in Europe. First, in March 1999, the European Court of Justice (ECJ) ruled in the Centros case that Articles $43^{275}$ and $48^{276}$ of the Treaty Establishing the European Community require a Member State to register a branch of a company formed in accordance with the law of another Member State, even if the company conducts no business in the state where it is incorporated. ${ }^{277}$ Though the scope of the decision remains uncertain, some commentators in-

${ }^{272}$ Most importantly, Germany, France, and Portugal, apply the "real seat" theory. Sørensen \& Neville, supra note 26 , at 184 . Germany's Sitztheorie, for example, requires a company having its principal place of business in Germany to incorporate under German law; conversely a company that has its headquarters outside of Germany cannot incorporate under German law. Id. at 185-86. In contrast, the Netherlands, Ireland, Denmark, and the United Kingdom apply the U.S.-style incorporation theory of regulation, i.e., a company is regulated by the country in which it is incorporated, which can differ from where it is headquartered or does business. Id. at 183 .

${ }^{273}$ See id. at 185 ("A transfer of the head office requires dissolution of the corporation in the state of departure ... and reincorporation in the state of arrival.").

${ }^{274}$ ROMANO, GENIUS, supra note 4 , at 134. vant part:

${ }^{275}$ Article 43 of the Treaty Establishing the European Community reads, in rele-

[R] estrictions on the freedom of establishment of nationals of a Member State

in the territory of another Member State shall be prohibited. Such prohibition shall also apply to restrictions on the setting up of agencies, branches or subsidiaries by nationals of any Member State established in the territory of any Member State.

Treaty Establishing the European Community, Feb. 7, 1992, art. 43, reprinted in EUROPEAN UNION: SELECTED INSTRUMENTS TAKEN FROM TREATIES 117 (1999).

${ }^{276}$ Article 48 reads, in relevant part:

Companies or firms formed in accordance with the law of a Member State and having their registered office, central administration or principal place of business within the Community shall, for the purposes of this Chapter, be treated in the same way as natural persons who are nationals of Member States.

Id. at art. 48, reprinted in EUROPEAN UNION, supra note 275.

${ }_{277}$ See Case C-212/97, Centros Ltd. v. Erhvervs-og Selskabsstyrelsen, 1999 E.C.R. I-1459, [1999] 2 C.M.L.R. 551, 552 (holding that the "refusal to register constituted an obstacle to the exercise of the freedom of establishment"). 
terpret Centros as rejecting the "real seat" doctrine in the EU. ${ }^{278}$

While Centros arguably has cleared one obstacle to corporate charter competition, the European Commission is seeking to clear another obstacle through its draft Fourteenth Company Law Directive. In 1993, the Commission retained the consulting firm KPMG to examine company migration in Europe. The resulting report endorsed the incorporation theory of corporate charters and recommended the facilitation of company movement by allowing reincorporation without liquidation within the EU. ${ }^{279}$ In 1998, the European Commission announced that it would act on the KPMG recommendation by formulating and proposing a draft Fourteenth Company Law Directive. The proposal has been published, although it has not yet been formally tabled for the European Union Council of Ministers. ${ }^{280}$

It will take future $\mathrm{ECJ}$ case law to clarify the degree to which the Centros decision rejects the seat theory in the EU. ${ }^{281}$ Moreover, given the notoriously slow EU legislative process, it may take years (if not decades) before the Fourteenth Company Law Directive becomes effective. ${ }^{282}$ Still, the overall movement in the EU seems to be toward greater regulatory competition, through a broadening of the mutual recognition requirements (Centros) and a reduction in other barriers to reincorporation (Fourteenth Directive). This trend may have been influenced by the current conventional wisdom from the U.S. experience with corporate charter competition. EU authority Eddy Wymeersch, for example, cites Romano for the proposition that the U.S. experience is a "race for excellence," and suggests that Centros similarly could lead to a race to the top. ${ }^{283}$ However, the evidence presented in this Article casts doubt on this characterization of the U.S. experience. By extension, it suggests that the movement toward regulatory competition in the EU may be an unwise policy choice. Instead,

${ }^{278}$ See, e.g., EDDY WYMEERSCH, COMPANY LAW IN EUROPE AND EUROPEAN COMPANY LAW 23-24 (Financial Law Inst., Working Paper No. WP-2001-06, 2001) (noting that some have interpreted Centros as "giv[ing] preference to the incorporation theory over the seat theory").

${ }^{279}$ K.P.M.G. EUROPEAN BUS. CENTRE, STUdY ON TRANSFER OF THE HEAD OFFICE OF A COMPANY FROM ONE MEMBER STATE TO ANOTHER (1993).

${ }^{280}$ WYMEERSCH, supra note 278 , at 37 \& n.142.

${ }^{281}$ See id. at 23 ("[T] he real meaning of the [Centros] case is still controversial, awaiting further cases to be decided by the Court ....").

${ }^{282}$ For an illustration of the EU legislative process in a related context, see Michelle Kalka \& Guhan Subramanian, The EU Takeover Directive (Harvard Bus. Sch., Note No. N9-902-066, Oct. 26, 2001), which chronicles the EU takeover directive first formally proposed in 1990 and still not yet enacted.

${ }^{283}$ WYMEERSCH, supra note 278 , at 24-25. 
harmonization may be preferable to mutual recognition of rules in order to achieve corporate law convergence in the EU. ${ }^{284}$

\section{CONCLUSION}

This Article provides empirical evidence on the U.S. corporate charter marketplace in the $1990 \mathrm{~s}$. The primary finding is that managers generally migrate to (and fail to migrate away from) the typical state antitakeover statutes. As a result, states that pass these statutes do well in the corporate charter marketplace (e.g., Nevada), while states that do not pass them do poorly (e.g., California). Empirical evidence from the financial economics literature suggests that antitakeover statutes reduce shareholder value. Therefore, assuming that states compete to maximize the number of companies incorporating within their boundaries (a standard assumption on both sides of the "race" debate), the pressure to pass antitakeover statutes in order to attract incorporations seems best characterized as a race to the bottom.

In addition to providing affirmative evidence in support of a race to the bottom, this Article challenges prior evidence that has been offered in support of a race to the top. For example, the well-known migration to Delaware during the $1990 \mathrm{~s}$, characterized by many commentators as evidence of a race to the top, is in large part a move away from California, a state well known for its greater protection of shareholder interests than Delaware. Similarly, the high opt-out rate from the Pennsylvania antitakeover statute is in fact an exception; among the more typical antitakeover statutes, opt out is extremely rare. Finally, the evidence that Delaware firms have higher Tobin's $Q$ than non-Delaware firms is not as stable as prior commentators have assumed; ${ }^{285}$ moreover, others have shown that this result does not necessarily imply a race to the top. ${ }^{286}$

${ }^{284}$ In fact, competition for corporate charters may be a quicker race to the bottom in Europe than in the U.S., because the forces that have improved corporate governance in the U.S. have been slower to take hold in Europe, and European countries have had a long tradition of considering other (nonshareholder) constituencies in corporate decision making. (One manifestation of this phenomenon, of course, is German co-determination, under which shareholders and employees have equal representation on the "supervisory" board (Aufsichstrat).) In particular, the "overreaching" phenomenon, which may place an important constraint on the race to the bottom in the United States, may not exist in the EU.

${ }^{285}$ Subramanian, supra note 68.

${ }^{286}$ See Bar-Gill, Barzuza, \& Bebchuk, supra note 66, at 23 ("Findings of Delaware marginal superiority do not address the question of how well state competition is per- 
While the evidence presented here is generally consistent with a race to the bottom, I also present evidence suggesting some limits on this view. Managers migrate to states with typical antitakeover statutes, but not to the three states with severe antitakeover statutes-Massachusetts, Ohio, and Pennsylvania. This result may be due to improved corporate governance in the 1990s, which may make these severe statutes "insignificantly redistributive" in the corporate charter marketplace. Thus state legislatures may be overreaching by passing statutes that go beyond the usual antitakeover protections provided by the states.

More broadly, this Article sheds additional light on the closely related debate on federalization of corporate law. The evidence presented in this Article suggests that, as a matter of public policy, we cannot rely on the product market, the capital market, or the market for corporate control to exert pressure on managers so that they migrate away from the typical antitakeover statutes. Instead, the largesample evidence shows that managers are able to pursue private benefits of control by moving to states with such statutes. States, in turn, can be expected to (and do) cater to this interest. A mandatory choice rule allowing shareholders to select unilaterally their state of incorporation would be an important step forward in the U.S. charter market. ${ }^{287}$ For the European Union, the findings presented here suggest that the current movement toward increased regulatory competition may be a poor public policy choice; instead, regulatory harmonization of corporate law may be the better (if politically more difficult) solution.

forming overall and, in particular, whether it performs better than would an alternative regime.").

${ }_{287}$ Bebchuk \& Ferrell, A New Approach, supra note 6, at 153 . 


$$
\text { * * * * * * * * }
$$

